\title{
Monticello BWR Spent Fuel Assembly Decay Heat Predictions and Measurements
}

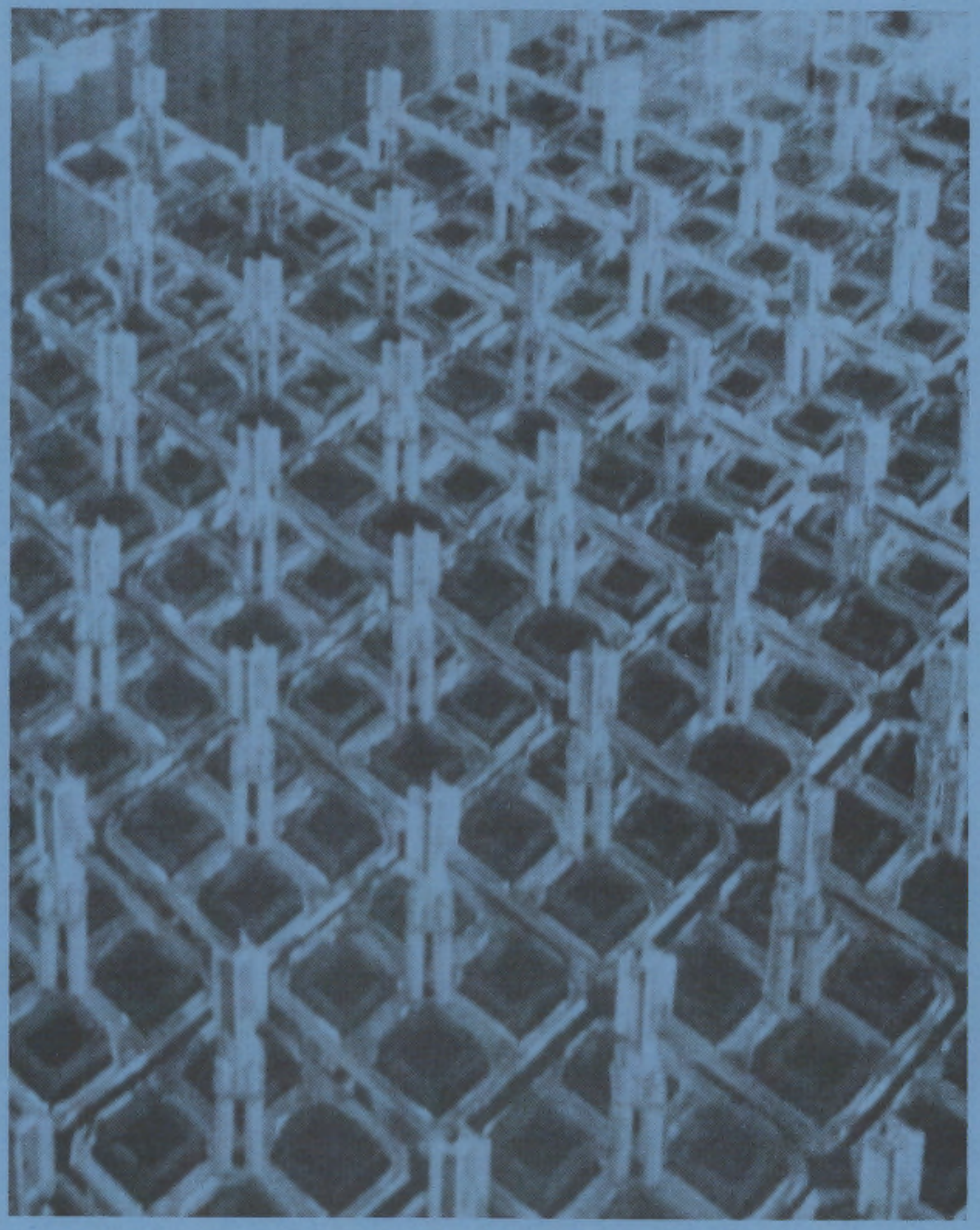

Prepared for the U.S. Department of Energy under Contract DE-AC06-76RLO 1830

Pacific Northwest Laboratory Operated for the U.S. Department of Energy by Battelle Memorial Institute 


\title{
DISCLAIMER
}

This report was prepared as an account of work sponsored by an agency of the United States Government. Neither the United States Government nor any agency thereof, nor any of their employees, makes any warranty, express or implied, or assumes any legal liability or responsibility for the accuracy, completeness, or usefulness of any information, apparatus, product, or process disclosed, or represents that its use would not infringe privately owned rights. Reference herein to any specific commercial product, process, or service by trade name, trademark, manufacturer, or otherwise, does not necessarily constitute or imply its endorsement, recommendation, or favoring by the United States Government or any agency thereof. The views and opinions of authors expressed herein do not necessarily state or reflect those of the United States Government or any agency thereof.

\author{
PACIFIC NORTHWEST LABORATORY \\ operated by \\ BATTELLE \\ for the \\ UNITED STATES DEPARTMENT OF ENERGY \\ under Contract DE-AC06-76RLO 1830
}

\begin{tabular}{|c|c|}
\hline \multicolumn{2}{|c|}{ Printed in the United States of America } \\
\hline \multicolumn{2}{|c|}{ Available from } \\
\hline \multirow{2}{*}{\multicolumn{2}{|c|}{$\begin{array}{l}\text { National Technical Information Service } \\
\text { United States Department of Commerce }\end{array}$}} \\
\hline & \\
\hline \multicolumn{2}{|c|}{5285 Port Royal Road } \\
\hline \multicolumn{2}{|c|}{ Springfield, Virginia 22161} \\
\hline \multirow{2}{*}{\multicolumn{2}{|c|}{$\begin{array}{l}\text { NTIS Price Codes } \\
\text { Microfiche A01 }\end{array}$}} \\
\hline & \\
\hline \multicolumn{2}{|c|}{ Printed Copy } \\
\hline & Price \\
\hline Pages & Codes \\
\hline $001-025$ & $\mathrm{AO2}$ \\
\hline $026-050$ & $\mathrm{~A} 03$ \\
\hline 051-075 & A04 \\
\hline $076-100$ & A05 \\
\hline $101-125$ & A06 \\
\hline $126-150$ & A07 \\
\hline $151-175$ & $\mathrm{~A} 08$ \\
\hline $176-200$ & A09 \\
\hline $201-225$ & A010 \\
\hline $226-250$ & A011 \\
\hline $251-275$ & A012 \\
\hline $276-300$ & A013 \\
\hline
\end{tabular}


MONTICELLO BWR SPENT FUEL ASSEMBLY DECAY HEAT PREDICTIONS AND

MEASUREMENTS
M. A. Mckinnon
J. W. Doman (a)
C. M. Heeb
J. M. Creer

June 1986

Prepared for

the U.S. Department of Energy

under Contract DE-AC06-76RLO 1830

Pacific Northwest Laboratory

Richland, Washington 99352

(a) General Electric-Morris Operation, Morris, Illinois 
. 


\section{ACKNOWLEDGMENTS}

This report presents the results of analyses and experimental work conducted by the Pacific Northwest Laboratory (PNL) and General Electric-Morris Operation (GE-MO) for the U.S. Department of Energy (DOE). The authors would like to acknowledge those from DOE, GE-MO, Monticello, and Los Alamos National Laboratory (LANL) who contributed to the project.

Appreciation is extended to Jim Daily, Phil Craig, and Gary Bracken of the DOE Richland Operations Office for sponsoring this work. Dale Oden, Jr., Darrell Newman, and Gordon Beeman of the Commercial Spent Fuel Management Program office managed by PNL are acknowledged for their support and guidance during the study.

The authors would like to recognize the following General Electric personnel for their efforts on the project: Carl king for management support at General Electric Sunnyvale, Gene Voiland and Eugene Ingels for management support at GE-MO, and the staff at GE-MO for operation of the calorimeter and ION-1/fork measurement system.

Appreciation is extended to Phillip Rinard and Gene Bosler of LANL for providing the ION-1 system used to obtain axial radiation profiles of each spent fuel assembly. Their assistance in setting up the instrument and in training the GE-MO staff in its operation was helpful.

Thanks are extended to Northern States Power Company's Monticello Nuclear Generating plant for use of their spent fuel assemblies. 


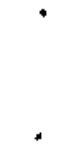




\section{EXECUTIVE SUMMARY}

This report compares pre-calorimetry predictions of decay heat rates of six $7 \times 7$ boiling water reactor (BWR) spent fuel assemblies with measured decay heat rates. The assemblies were from Northern States Power Company's Monticello Nuclear Generating Plant and had burnups of 9 to 21 GWd/MTU and cooling times of 9 to 10 years. This study is an extension of the decay heat work performed with Commonwealth Edison's Dresden Nuclear Power Station BWR spent fuel and Nebraska Public Power District's Cooper Nuclear Station BWR spent fuel by the Electric Power Research Institute (EPRI) and U.S. Department of Energy (DOE) to evaluate the ORIGEN2 computer code. The Dresden fuel had burnup values of 5 GWd/MTU and cooling times of 11 to 12 years, and the Cooper fuel had burnup values of 20 to 28 GWd/MTU and cooling times of 2 to 4 years.

Predictions were made prior to calorimetry to facilitate an unbiased comparison of predictions with measurements. The predictions were made with a standard version of the ORIGEN2 computer code using the standard BWR cross section library for a ${ }^{235} U$ enriched fuel. Before the code was used for the decay heat predictions in this study, it was compared to another standard version of the code on a different computer and found to be operating satisfactorily.

Two types of measurements were made on the fuel assemblies: decay heat measurements and axial radiation measurements. The decay heat measurements were made using an existing in-pool calorimeter that was designed, constructed, and tested by General Electric's Morris Operation (GE-MO) for DOE. Concurrent with its use in this test program, the calorimeter was calibrated using an electric heater. Corrections were applied to spent fuel assembly measurements to account for differences in heat capacity (ratio of heat supplied to corresponding temperature rise) and radiation losses between the calibration and measurement modes.

The predicted decay heat values were found to be $0 \pm 15 \mathrm{~W}$ less than measured values when using a 1984 calibration method, or $21 \pm 2 \mathrm{~W}$ when a 1985 calibration method was used, as shown in Figure S.1. Precision depends on the measurement technique, and the accuracy is associated with the calibration 


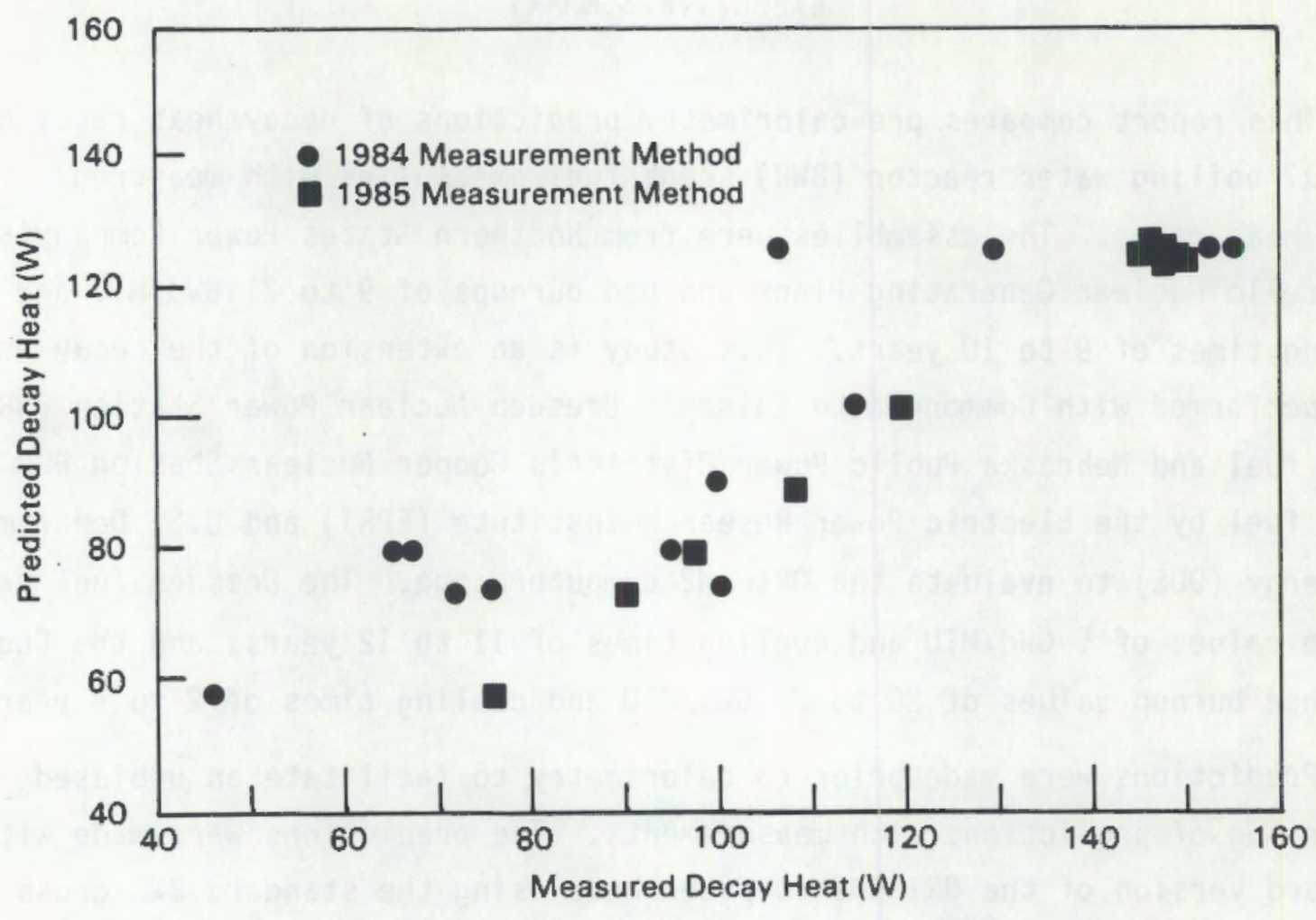

FIGURE S.1. Predicted and Measured Decay Heat Rates for Monticello Spent Fuel

process. The data collected in this study agree well with calorimetry data collected previously for Dresden and Cooper fuel assemblies, as shown in Figure S.2. This study also indicated that it may be possible to increase the precision of the calorimeter by reducing the uncertainty in the calibration process and by better defining and adhering to operating procedures.

A set of radiation measurements was made to determine the axial gamna and neutron profiles of each assembly. The measurements were made at nine preselected elevations with an ION-1/fork measurement system developed by Los Alamos National Laboratory and provided to GE-MO. Comparisons were made between predictions of axial decay heat profiles and gamma profile measurements. The pre-calorimetry predictions were based on core-averaged axial 


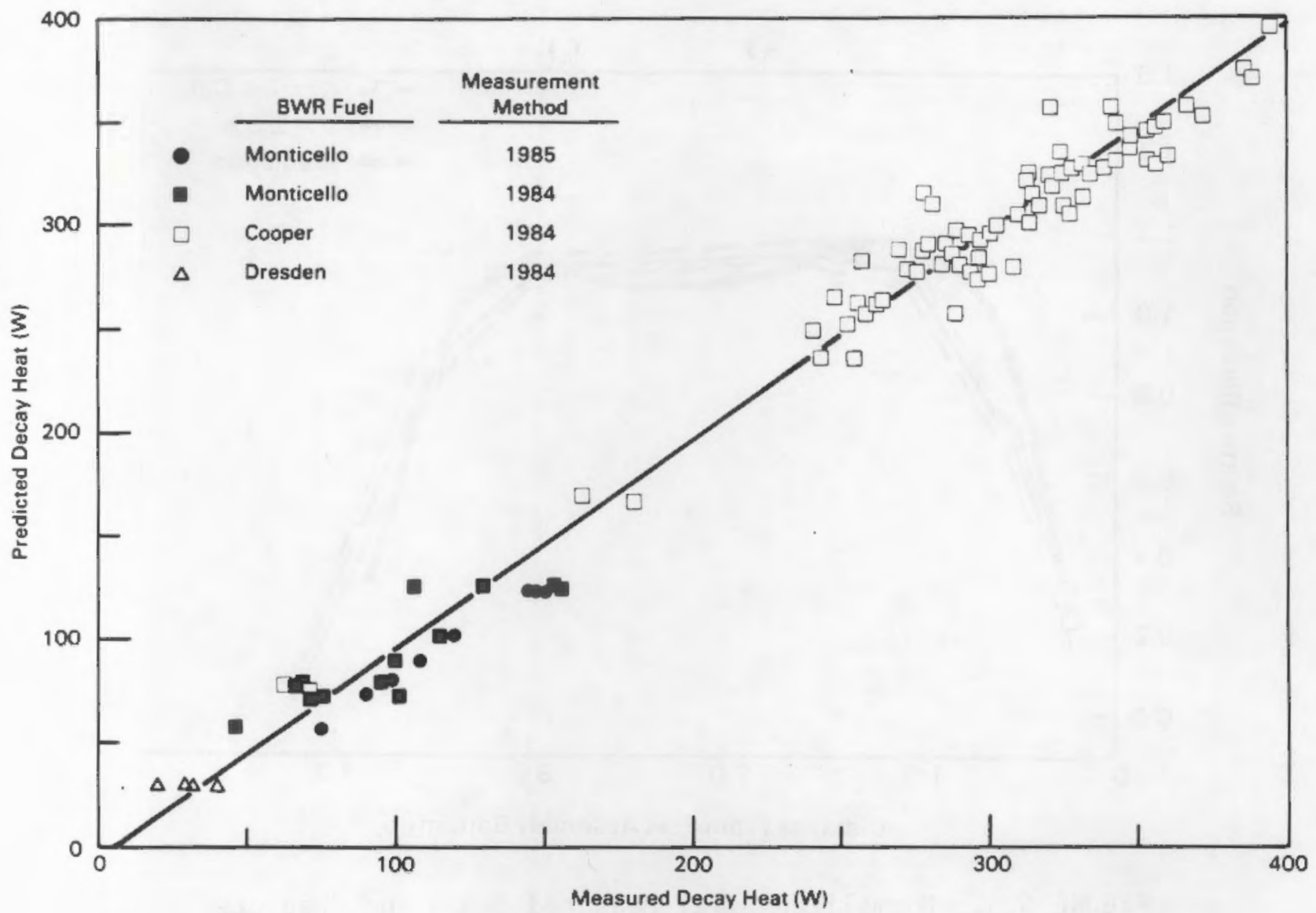

FIGURE S.2. Predicted and Measured Decay Heat Rates for BWR Spent Fuel Assemblies

burnup distributions and assumed that gamma-ray source strengths were proportional to burnup for burnups above $5.0 \mathrm{GWd} / \mathrm{MTU}$. A comparison between predicted decay heat and measured gamma axial profiles is shown in Figure S.3. The agreement between the two curves is good. 


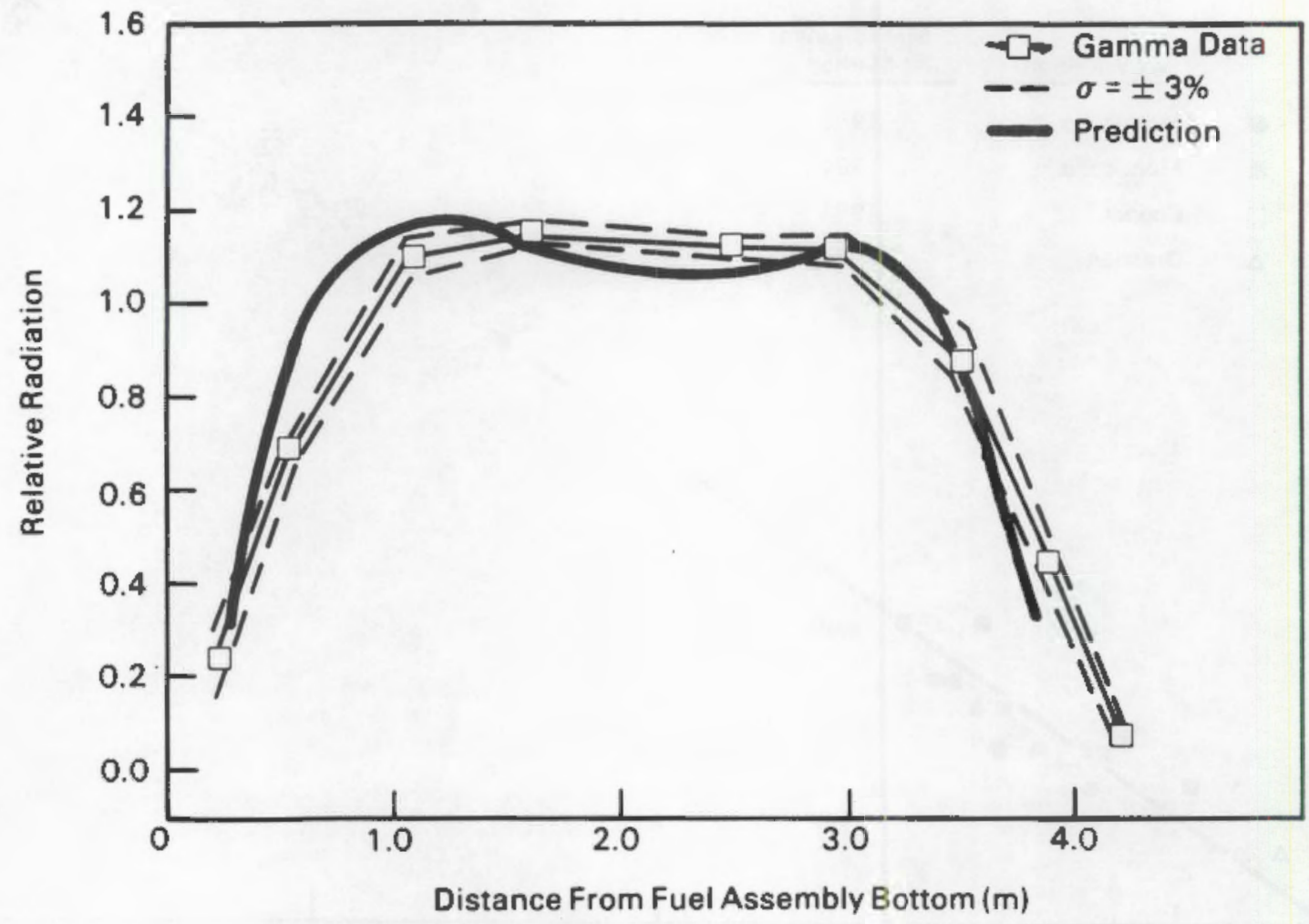

FIGURE S.3. Normalized Axial Measured Gamma and Predicted Decay Heat Profiles 


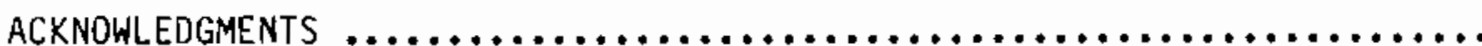

EXECUTIVE SUMMARY $\ldots \ldots \ldots \ldots \ldots \ldots \ldots \ldots \ldots \ldots \ldots \ldots \ldots \ldots \ldots \ldots \ldots \ldots \ldots \ldots$

ACRONYMS AND INITIALISMS $\ldots \ldots \ldots \ldots \ldots \ldots \ldots \ldots \ldots \ldots \ldots \ldots \ldots \ldots \ldots \ldots \ldots \ldots \ldots \ldots \ldots$

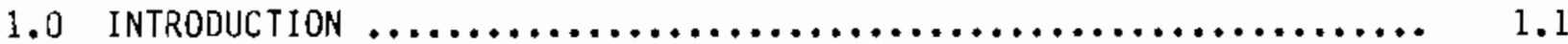

2.0 CONCLUSIONS AND RECOMMENDATIONS $\ldots \ldots \ldots \ldots \ldots \ldots \ldots \ldots \ldots \ldots \ldots \ldots \ldots$

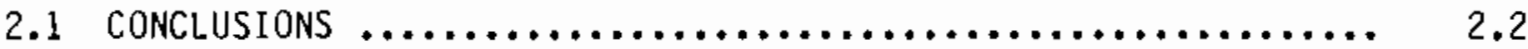

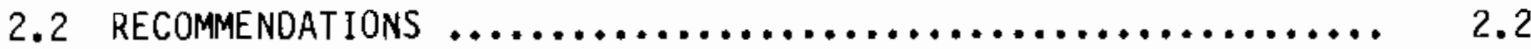

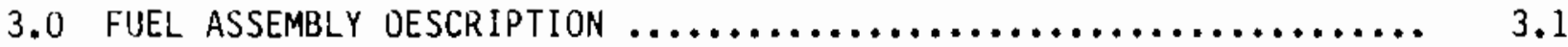

4.0 MEASUREMENT EQUIPMENT AND EXPERIMENTAL DATA $\ldots \ldots \ldots \ldots \ldots \ldots \ldots \ldots \ldots . . \ldots$

4.1 CALORIMETER AND DECAY HEAT DATA $\ldots \ldots \ldots \ldots \ldots \ldots \ldots \ldots \ldots \ldots \ldots \ldots \ldots \ldots$

4.2 ION-1 SYSTEM AND AXIAL RADIATION DATA $\ldots \ldots \ldots \ldots \ldots \ldots \ldots \ldots . . \ldots \ldots$

5.D DECAY HEAT ANALYSIS AND DATA COMPARISONS $\ldots \ldots \ldots \ldots \ldots \ldots \ldots \ldots \ldots . . \ldots$

5.1 ORIGEN2 CUMPUTER CODE $\ldots \ldots \ldots \ldots \ldots \ldots \ldots \ldots \ldots \ldots \ldots \ldots \ldots \ldots \ldots \ldots \ldots \ldots \ldots \ldots \ldots$

5.2 ORIGEN2 INPUT SPECIFICATIUNS $\ldots \ldots \ldots \ldots \ldots \ldots \ldots \ldots \ldots \ldots \ldots \ldots \ldots \ldots \ldots \ldots$

5.3 ORIGEN2 PREDICTIONS COMPARED TO DATA $\ldots \ldots \ldots \ldots \ldots \ldots \ldots \ldots \ldots . . \ldots$

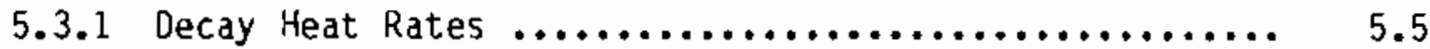

5.3 .2 Axia] Decay Heat Profiles .................... 5.12

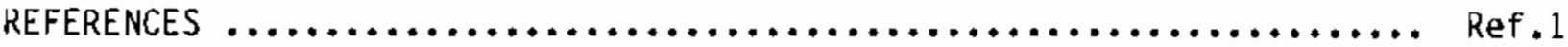

APPENDIX A - CALORIMETER DATA AND CORRECTION FACTORS .............. A.I

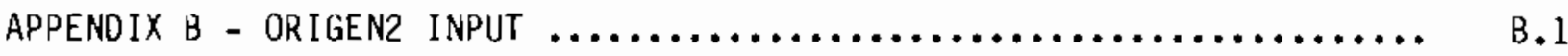


FIGURES

S.1 Predicted and Measured Decay Heat Rates for Monticello

Spent Fuel $\ldots \ldots \ldots \ldots \ldots \ldots \ldots \ldots \ldots \ldots \ldots \ldots \ldots \ldots \ldots \ldots \ldots \ldots \ldots$ vi

S.2 Predicted and Measured Decay Heat Rates for BWR Spent

Fuel Assemblies ................................. vi

S.3 Normalized Axial Measured Gamma and Predicted Decay

Heat Profiles .................................. viji

3.1 Monticello Fuel Assembly $\ldots \ldots \ldots \ldots \ldots \ldots \ldots \ldots \ldots \ldots \ldots \ldots \ldots . \ldots \ldots$

General Electric-Morris Operation In-Pool Calorimeter and
Associated Equipment $\ldots \ldots \ldots \ldots \ldots \ldots \ldots \ldots \ldots \ldots \ldots \ldots \ldots \ldots \ldots \ldots$

4.2 Calorimeter Time-Versus-Temperature Calibration Curves ...... 4.5

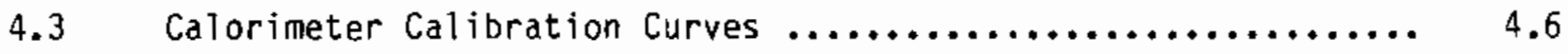

4.4 Los Alamos ION-1 Spent Fuel Radiation Measurement Equipment ... 4.9

4.5 Monticello Spent Fuel Axial Gamma Profiles ................ 4.. 42

4.6 Monticello Spent Fuel Axial Neutron Profiles .............. 4.12

Monticello Spent Fuel Normalized Gamma Axial Radiation
Profile $\ldots \ldots \ldots \ldots \ldots \ldots \ldots \ldots \ldots \ldots \ldots \ldots \ldots \ldots \ldots \ldots \ldots \ldots \ldots \ldots \ldots \ldots \ldots \ldots \ldots \ldots \ldots \ldots \ldots \ldots$

4.8 Monticello Spent Fuel Normalized Neutron Axial Radiation

Profile ........................................... 4.13

5.1 Monticello Reactor Operating History (Cycles 1 through 4) $\ldots . .4 .4$

5.2 Monticello Assembly MT133 Specific Power History ........... 5.4

5.3 Predicted and Measured Monticello Spent Fuel Decay Heat

Rates Obtained Using the 1984 Measurement Method ............ 5.7

5.4 Predicted and Measured Montice110 Spent Fue1 Decay Heat

Rates Obtained Using the 1985 Measurement Method ............. 5.7

5.5 Comparison of Measurement Method Effect on Predicted and

Measured Monticello Spent Fuel Decay Heat Rate ............. 5.8

5.6 Predicted and Measured Decay Heat Rates for Dresden, Cooper, and Monticello Spent Fuel Assemblies .................... 5.9

5.7 All Calorimeter Calibration Curves $\ldots \ldots \ldots \ldots \ldots \ldots \ldots \ldots \ldots \ldots \ldots \ldots$ 
5.8 Monticello Spent Fuel Assembly Measured Average Axial Gamma Profile and Predicted Axial Decay Heat Profile ............. 5.13

B.1 Monticello Assembly MT116 Power History .................. B...

8.2 Monticello Assembly Mr123 Power History .................. B...

B.3 Monticello Assembly MT133 Power History ................ B.4

B.4 Monticello Assembly MT190 Power History ................. 8.4

B.5 Monticello Assembly MT228 Power History ................. B.5

B.6 Monticello Assembiy MT264 Power History ................... B.5 


\section{TABLES}

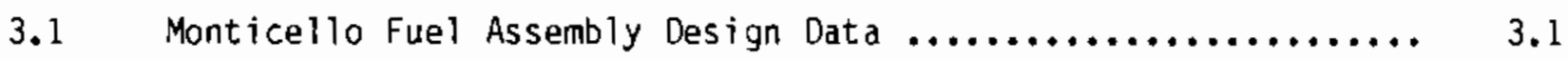

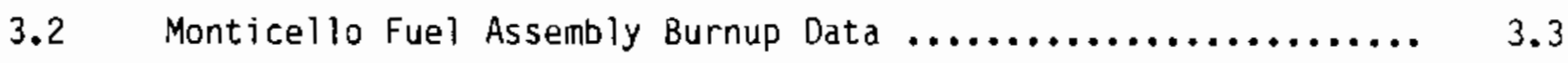

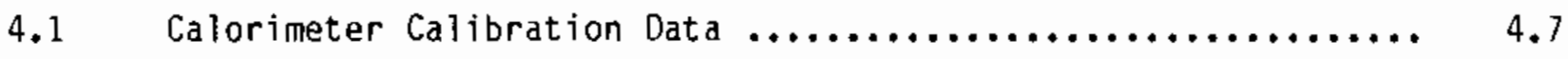

4.2 Monticello Spent Fuel Assembly Calorimetry Results $\ldots \ldots \ldots \ldots . .4 .8$

4.3 Monticello Spent Fuel Axial Gamma Radiation Profiles ......... 4.11

4.4 Monticello Spent Fuel Axial Neutron Radiation Profiles ....... 4.11

5.1 Monticello Spent Fuel Assembly Calorinetry Results .......... 5.6

5.2 Dresden Assembly ON212 Repeat Measurements ............... 5.11

A.1 Summary of Cooper and Dresden BWR Calorimetry Data .......... A.15

B.1 Monticello Spent Fuel Assembly Operating History ............ B.1 
ACRONYMS AND INITIALISMS

$\begin{array}{ll}\text { BWR } & \text { boiling water reactor } \\ \text { DOE } & \text { U.S. Department of Energy } \\ \text { EOC } & \text { end-of-cycle } \\ \text { EPRI } & \text { Electric Power Research Institute } \\ \text { GE-MO } & \text { General Electric-Morris Operation } \\ \text { H/U } & \text { hydrogen-to-uranium (ratio) } \\ \text { LANL } & \text { Los Alamos National Laboratory } \\ \text { NRC } & \text { U.S. Nuclear Regulatory Comnission } \\ \text { NWPA } & \text { Nuclear Waste Policy Act } \\ \text { ORNL } & \text { Dak Ridge National Laboratory } \\ \text { PNL } & \text { Pacific Northwest Laboratory } \\ \text { PWR } & \text { pressurized water reactor } \\ \text { RTD } & \text { resistance temperature detector }\end{array}$


, 


\author{
MONTICELLO BWR SPENT FUEL ASSEMBLY \\ DECAY HEAT PREOICTIONS AND MEASUREMENTS
}

\title{
1.0 INTRODUCTION
}

No facility is currently licensed by the U.S. Nuclear Regulatory Commission (NRC) for final disposal or reprocessing of spent nuclear fuel. However, by virtue of the Nuclear Waste Poljcy Act of 1982 (NWPA), the federal yovernment has made a specific commitment to accept commercially generated nuclear wastes for disposal by 1998. By the mid-1980s several reactor pool storage basins will have attained maximum capacity. As a consequence, interim storage of spent fuel must be provided. If it is not, the continued operation of nuclear-powered electric generation stations may be jeopardized. Options for dry storage of spent fuel at reactors are being developed by the utility industry and the U.S. Department of Energy (DOE) to minimize the possibility of reactor shutdowns due to lack of spent fuel storage capacity.

Because analyses and testing of dry storage systems are required to support NRC license applications, the utilities and DOE are actively pursuing research, development, and demonstration of dry storage systems. Experimental data to support at-reactor dry storage license applications could greatly reduce the effort and time required to process applications. However, the data must adequately characterize a storage system and must be obtained using welldocumented procedures.

Accurate determination of spent fuel decay heat rates is a critical step in tests, demonstrations, and licensing activities associated with characterizing a storage facility because peak cladding temperatures are dependent on the heat generation rates of the spent fuel assemblies. To deterinine the maximum heat dissipation capacity of a spent fuel storage system, the total heat being generated must be accurately known.

For most tests and at-reactor demonstrations of dry storage systems, obtaining accurate spent fuel decay heat measurements is impractical. Only two calorimeters are known to exist that can be used to measure the decay heat output of complete spent fuel assemblies. One calorimeter is at the Engine 
Maintenance and Disassembly Facility operated by Westinghouse Electric Corporation on the Nevada Test Site; the other is at General Electric's Morris Operation (GE-MO) in Morris, Illinois. Therefore, it is highly desirable to show that computer codes such as ORIGEN2 (Croff 1980a,b) can be used to accurately predict assembly decay heat generation rates.

The evaluation and determination of the accuracy of the ORIGEN2 computer program is extremely important to the success of tests and licensed at-reactor dry storage demonstrations. Also, future license applications for interim storage of spent fuel at reactors will be dependent on the accuracy of codes such as ORIGEN2 for decay heat predictions. A DOE study involving pressurized water reactor (PWR) calorimetry has demonstrated that ORIGEN2 predictions compare favorably with calorimetry data for PWR fuel (Schmittroth 1984). Similar studies sponsored by the Electric Power Research Institute (EPRI) and DDE investigated the ability to predict decay heat rates of BWR $7 \times 7$ spent fuel assemblies from Comnonwealth Edison's Dresden Nuclear Power Station and Nebraska Public Power District's Cooper Nuciear Station (Mckinnon et a1. 1985, 1986). The Dresden spent fuel assemblies had burnup values of 5 GWd/MTU, cooling times of 11 to 12 years, and decay heat rates of less than $50 \mathrm{~W}$. The Cooper assemblies had burnup values of 20 to $28 \mathrm{GWd} / \mathrm{MTU}$, cooling times of 2 to 4 years, and decay heat rates near $300 \mathrm{~W}$. The Dresden and Cooper spent fuel data did not allow the ORIGEN2 code to be adequately evaluated for intermediate decay heat values.

The objectives of the study reported herein were to perform precalorimetry decay heat predictions of selected Monticello 8 WR spent fuel assemblies with lower decay heat output than was possible with the Cooper fuel, and to compare predictions to in-pool calorimetry data. This report includes the results of the pre-calorimetry analysis, a description of the Monticello BWR spent fuel assemblies, calorimeter decay heat measurements, axial radiation scans, and a comparison of the pre-calorimetry predictions to experimental data. The results of this study show that ORIGEN2 can satisfactorily predict the decay heat of $8 W R$ fuel when the decay heat rate is $50 \mathrm{~W}$ or greater. The predictions were made prior to any data being available, to facilitate an unbiased comparison of predictions with measurements. 


\subsection{CONCLUSIONS ANO RECOMMENDATIONS}

The results of this study show that ORIGEN2 predictions of BWR spent fuel assembly decay heat rates agree with all experimental BWR calorimeter data within a standard deviation of $\$ 15 \mathrm{~W}$. The agreement between ORIGEN2 predictions and decay heat measurements of Monticelio spent fuel is dependent on the method used to maxe the decay heat measurements and on the process used to calibrate the calorimeter. For the Monticello spent fuel studied, the predictions are within $0 \pm 15 W$ and $21 \pm 2 W$ for the 1984 and 1985 measurement methods, respectively. The accuracy of the calorimeter depends on the calibration process, whereas the precision of the measurement is related to the measurement method.

From this study and previous studies (Schmittroth 1984; Mckinnon et al. 1985, 1986), it can be concluded that ORIGEN2 predicts decay heat rates of spent fuel assemblies satisfactorily when decay heat magnitudes are on the order of $50 \mathrm{~W}$ and greater. Spent fuel storage system tests and demonstrations simulating at-reactor or interim storage systems can be performed adequately using ORIGEN2 predictions of decay heat rates and do not absolutely require experimental calorimetry of each fuel assembly. However, to obtain satisfactory results, the ORIGEN2 predictions must be performed using detailed input information, especially burnup histories.

Results of this study are not applicable to old fuel that has very low decay heat rates. It is anticipated that decay heat predictions of actinides, where decay heats are significant in old, cold fuel, may be a problem and should be addressed. An evaluation of ORIGEN2 for predicting decay heat rates of old, cold fuel is required to verify prediction accuracies.

The following subsections present the specific conclusions and recommendations developed during this study. 


\subsection{CONCLUSIONS}

The results of the decay heat predictions and measurements permit the following conclusions:

- The agreement between ORIGEN2 predictions and decay heat measurements of Monticello spent fuel is dependent on the method used to calibrate the calorimeter and to make the decay heat measurements.

- The agreement between predictions and measurements of decay heat rates of Monticello fuel is the same as that for Cooper and Oresden fuel if the same measurement method is used. The predictions are within a standard deviation of $\pm 15 \mathrm{~W}$ of the measurements.

- Using a different measurement method, ORIGEN2 underpredicts the measured decay heat output of Monticello fuel assemblies by a constant $20 \pm 2 \mathrm{~W}$. The $20-\mathrm{W}$ offset appears to be an artifact of the calibration procedure.

- The constant term in the calibration curve (i.e., $\left.9_{D H}=m x+b\right)$ can account for measurement differences of $40 \mathrm{~W}$ based on the 1983, 1984, and 1985 calibration curves.

- The difference between ORIGEN2 predictions and calorimeter decay heat measurements does not appear to be dependent on the magnitude of decay heat output.

- Predicted axial decay heat profiles are in good agreenent with measured axial gamma radiation profiles.

\subsection{RECOMMENDATIONS}

The results and conclusions of this study led to the following recommendations:

- Predictions using other decay heat codes should be compared to experimental data contained in this report, to evaluate prediction capabilities. 
- The source of the differences that exist among calorimeter calibration curves needs to be determined.

- Calorimeter operational methods need to be investigated further to determine cause and effect relationships between operational method and calorimeter precision and accuracy. 


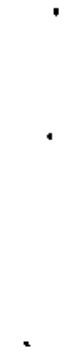




\subsection{FUEL ASSEMBLY DESCRIPTION}

The BWR spent fuel assemblies used in this study were from Northern States Power Company's Monticello Nuclear Generating Plant. The assemblies were of the $7 \times 7$ GE design. The design details are given in Table 3.1 and illustrated schematically in Figure 3.1. The upper and lower tie plates are 304 stainless steel castings. The lower tie plates have nose-pieces that support the fuel assemblies in the reactor. The upper tie plates have lifting bails for handling the fuel assemblies.

In addition to the standard fuel rods, each assembly has eight fuel rods that are used as tie rods that thread into the lower tie plate casting. The upper ends of the fuel/tie rods extend through and are fastened to the upper tie plate with stainless steel nuts and locking tabs. These fuel/tie rods support the weight of an assembly during fuel-handling operations when the assembly hangs by the bail. The center rod of each fuel assembly has been designed to maintain the position of the fuel rod spacers. It is inserted into the fuel assembly and rotated to lock the spacers into their respective locations. The spacers have Inconel springs to maintain rod-to-rod spacing. The fuel rods were pressurized with helium and sealed by welding end plugs on each end.

TABLE 3.1. Monticello Fuel Assembly Design Data

$\begin{array}{lll}\text { Fuel rods per assembly } & 49 & \\ \text { Active fuel length } & 3.658 \mathrm{~m} & (144 \mathrm{in.}) \\ \text { Assembly length } & 4.354 \mathrm{~m} & (171.4 \mathrm{in.}) \\ \text { Rod-to-rod pitch } & 18.7 \mathrm{~mm} & (0.738 \mathrm{in.}) \\ \text { Cladding outside diameter } & 14.30 \mathrm{~mm} & (0.563 \mathrm{in.}) \\ \text { Cladding thickness } & 0.813 \mathrm{~mm} & (0.032 \mathrm{in.}) \\ \text { Pellet outside diameter } & 12.4 \mathrm{~mm} & (0.488 \mathrm{in.}) \\ \text { Initial plenum pressure } & 1.0 \mathrm{~atm} & \\ \text { Initial } 235 \mathrm{U} & 2.25 \mathrm{wt} \% & \\ \text { Zircaloy-2 weight } & 42.000 \mathrm{~kg} / \text { ass. } & (92.59 \mathrm{ib} / \mathrm{ass} .) \\ 304 \text { stainless steel weight } & 8.600 \mathrm{~kg} / \text { ass. } & (18.96 \mathrm{lb} / \mathrm{ass} .)\end{array}$




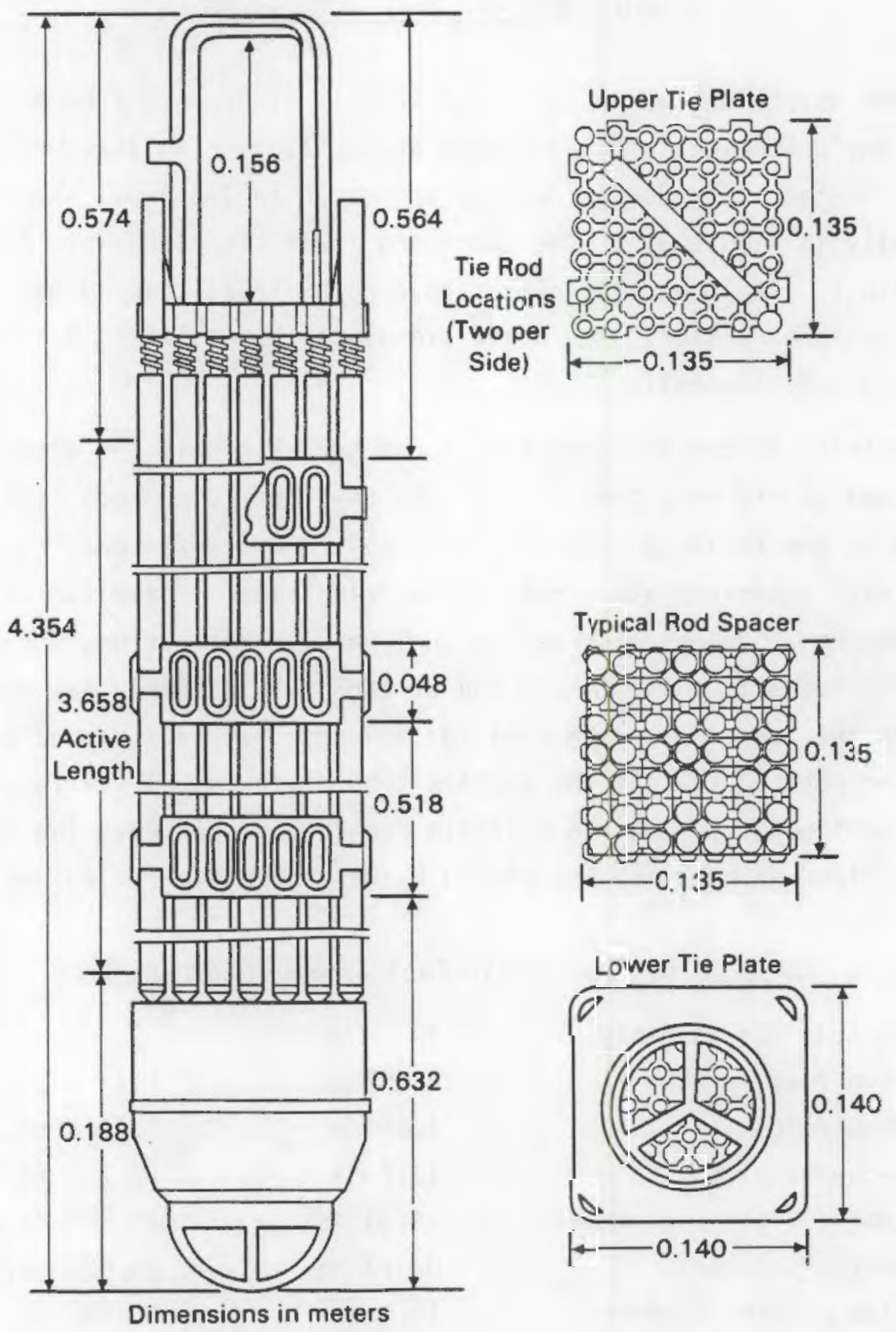

FIGURE 3.1. Monticello Fuel Assembly 
The Monticello spent fuel assemblies had been out of the reactor for 9 to 10 years prior to calorimetry and had burnup values ranging from 9 to 21 GWd/MTU as indicated in Table 3.2. Burnup values were provided from two different utility accounting methods. One method, termed form 30 reporting, is used by the utility to meet fuel storage requirements and lists only the final total burnup. The other method, referred to as Cycle Summary reporting, contains end-of-cycle (EOC) burnup values. Previous studies (McKinnon et al. 1985, 1986) have shown that cycle burnup values are required to make reasonable predictions of decay heat with the ORIGEN2 code. The information in Table 3.2 gives one source of cycle burnups and two sources of total burnups.

TABLE 3.2. Monticello Fuel Assembly Burnup Data

\begin{tabular}{|c|c|c|c|c|c|c|c|}
\hline $\begin{array}{l}\text { As semb ly } \\
\text { ID }\end{array}$ & $\frac{\text { Cycle }}{\text { Cycle } 1}$ & $\frac{\text { Summary }}{\text { Cycle } 2}$ & $\frac{\text { Burnup Val }}{\text { Cycle } 3}$ & $\frac{\text { es, MWd } / 1}{\text { Cycle } 4}$ & U Total & $\begin{array}{l}\text { Form } 30 \\
\text { Burnup, } \\
\text { MWd/MTU }\end{array}$ & $\begin{array}{l}\text { Ratio, } \\
\text { Form } 30 \\
\text { To Cycle } \\
\text { Summary }\end{array}$ \\
\hline MT116 & 8,294 & 4,583 & 1,389 & 3,215 & 17,482 & 18,040 & 1.03 \\
\hline MT123 & 9,074 & 5,078 & - & - & 14,152 & 13,030 & 0.92 \\
\hline MT133 & 8,552 & 4,786 & 3,452 & 3,398 & 20,189 & 21,000 & 1.04 \\
\hline MT190 & 5,054 & 2,927 & 3,495 & 3,836 & 15,312 & 15,150 & 0.99 \\
\hline MT228 & 3,652 & 1,936 & 3,458 & 3,524 & 12,570 & 12,130 & 0.97 \\
\hline MT264 & 4,059 & 2,068 & 1,915 & 2,047 & 10,089 & 9,160 & 0.91 \\
\hline
\end{tabular}

(a) End of Cycle 2 - March 16, 1974.

(b) End of Cycle 4 - September 13, 1975. 



\subsection{MEASUREMENT EQUIPMENT AND EXPERIMENTAL DATA}

In this section, the work performed at the General Electric-Morris Operation (GE-MO) facility is described. This work consisted of measuring the decay heat rates and axial radiation profiles of six Monticello BWR spent fuel assemblies. Decay heat rates were measured using an existing in-pool calorimeter previously designed, built, and tested by GE-MO in 1981 for DOE (Judson et al. 1982). Radiation profiles were obtained with a combined gamma and neutron measurement system developed at the Los Alamos National Laboratory (LANL) and referred to as the ION-1/fork measurement system (Halbig and Caine 1985).

\subsection{CALORIMETER AND DECAY HEAT DATA}

The in-pool calorimeter used at GE-MO for decay heat measurements is depicted schematically in Figure 4.1. Basically, the calorimeter is composed of two concentric pipes with an insulated annular space. The calorimeter is $4.6 \mathrm{~m}$ (15 ft) long and has a $0.4-\mathrm{m}(16-\mathrm{in}$.$) inner diameter. Fuel is placed in$ the calorimeter using a method very similar to that for loading a fuel transfer cask. The calorimeter cavity contains a fixed insert for PWR fuel and a removable insert for BWR fuel. These calorimeter inserts maintain fuel assemblies in centered vertical positions. The calorimeter utilizes resistance temperature detectors (RTDs) to measure temperatures and gamma sensors to quantify radiation losses.

During calorimetry, the system utilizes a Digistrip datalogger, a calibration tank, a sample pump, a purge system, a valve control panel, and gamma sensor readout devices. A heater power controller and a digital wattmeter are used during calibrations, but are not part of the normal equipment used during calorimetry. The calibration tank is used to prevent pressurization of the calorimeter, to leak-check the calorimeter after the fuel is loaded, and to collect calorimeter water samples. 


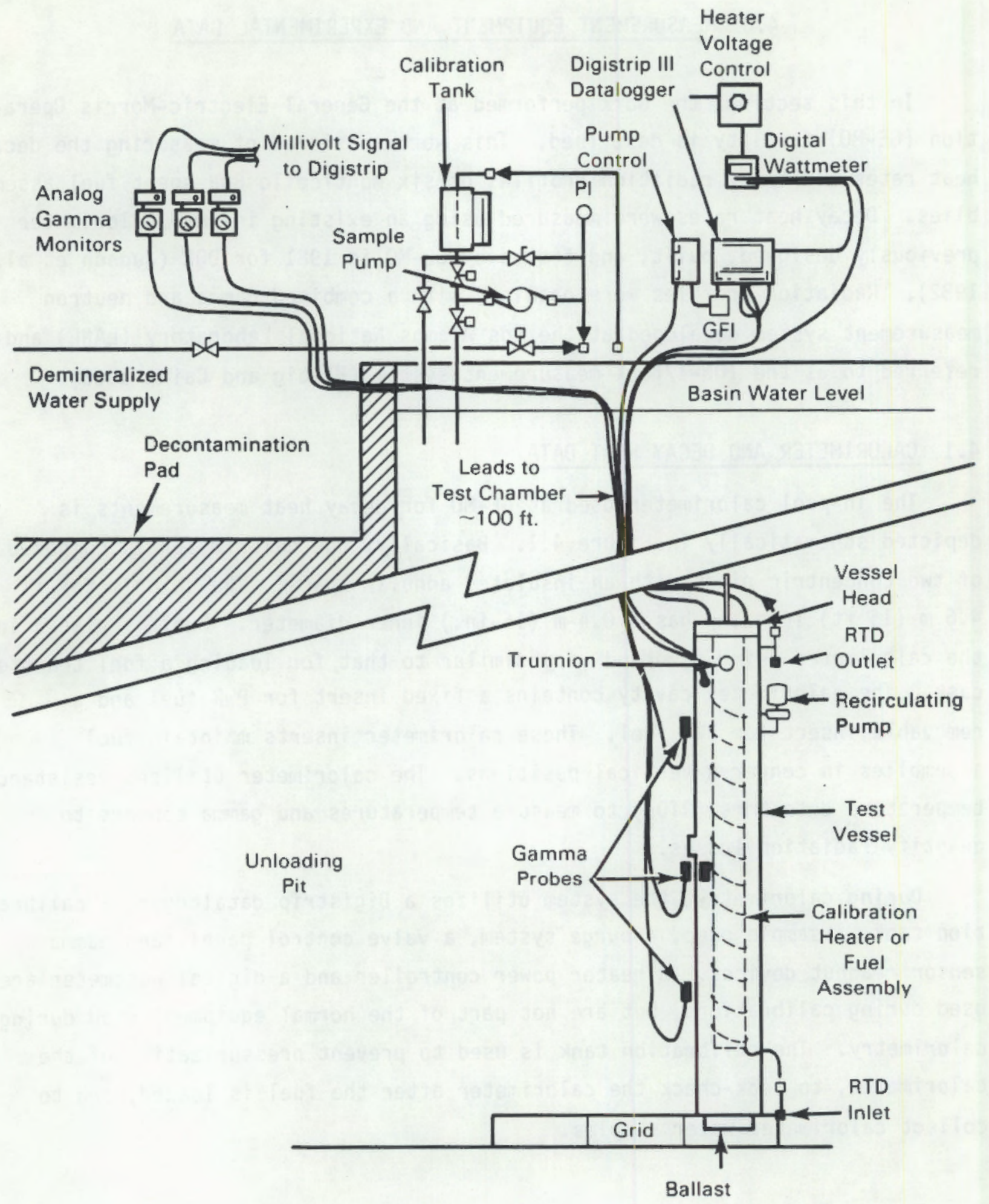

FIGURE 4.1. General Electric-Morris Operation In-Pool Calorimeter and Associated Equipment

Source: Mckinnon et al. (1985, p. 3-2) 
Two methods of calorimeter operation were used to obtain decay heat measurements of the Monticello spent fuel. The first method consisted of the following steps:

1. The vessel was purged to remove hot water.

2. The vessel was allowed to equilibrate with the surrounding basin water.

3. A delta $\mathrm{T}$ across the calorimeter of $0.0 \pm 0.055^{\circ} \mathrm{C}$ was maintained for 1 hour.

4. A fuel assembly was lowered into place.

5. The head was torqued down and leak-checked.

6. Automatic data acquisition was initiated when the datalogger showed a temperature difference of $0.55^{\circ} \mathrm{C}$ between the interior vessel surface and outside skin.

Additional care was exercised to maintain the unloading pit water at a constant temperature during the runs. This method was used also in previous studies (McKinnon et al. 1985, 1986) involving Dresden and Cooper reactor spent fuel.

The second method was identical to the first except for the third step. In the modified third step a delta $\mathrm{T}$ across the calorimeter of $0.2^{\circ} \mathrm{C}$ was obtained. This modification relaxed the time requirement and did not involve such strict control of the temperature.

Two separate calibrations of the calorimeter were performed using the above operating methods and by replacing the spent fuel assembly with an electric heater. A known amount of energy was put into the calorimeter, and the increase in internal temperature with time was observed. The power delivered to the calibration heater was controlled by a variable power transformer and measured by a precision wattmeter. The datalogger continuously monitored the signal and printed out average power at 15-minute intervals. The datalogger power printouts were then averaged over a 5 -hour interval to arrive at the "actual" power delivered to the calorimeter. This power was then corrected for the power lost in the heater leads external to the calorimeter. 
Each run lasted 5 hours from the time the datalogger was put into automatic operation. In 1984, calibration runs were made at $0,50,100,200,300$, 400 , and $500 \mathrm{~W}$, with a repeat run at $200 \mathrm{~W}$. Calibration runs in 1985 were obtained at $0,50,100,150,200$, and $300 \mathrm{~W}$, with repeat runs at 50, 100, and $150 \mathrm{~W}$. Two additional calibration runs were performed in 1985 using the 1984 method of operation to see if the 1984 calibration had shifted with time. The temperature-versus-time curves for the two calibration runs are shown in Figure 4.2.

The calibration curves shown in Figure 4.2 were converted to heat output in watts using the following technique: 1) a polynomial equation of the form $y=a x^{2}+b x+c$ was determined for each heat-up curve; 2) the slope of each line at $t=0$ was calculated; and 3 ) the relationship between "slope value" at $t=0$ and power was determined. This relationship is expressed by the calibration curves shown in Figure 4.3. The relationships are linear with correlation coefficients of 0.9996 for the 1984 and 1985 calibration curves determined from linear regression analysis of the data. The calibration equations are

$$
\text { Decay Heat }=372.545^{\star} \text { S1ope }-85.975 \text { for } 1984
$$

and

$$
\text { Decay Heat }=381.66^{\star} \text { Slope }-55.177 \text { for } 1985
$$

where the slope values are taken at time zero. The two calibration points taken in 1985 using the 1984 method of operation are also plotted in Figure 4.3. They do not fall on either of the calibration curves.

Table 4.1 lists the slope values and index of determination values for the 1984 and 1985 calibration runs. As can be seen from Table 4.1, the polynomial equations gave very good fits to the data above $50 \mathrm{~W}$ (index of determination values generally greater than 0.9999$)$. The repeatability of the individual calibrations based on repeat runs at 50,100, 150, and $200 \mathrm{~W}$ was about $1 \%$. 


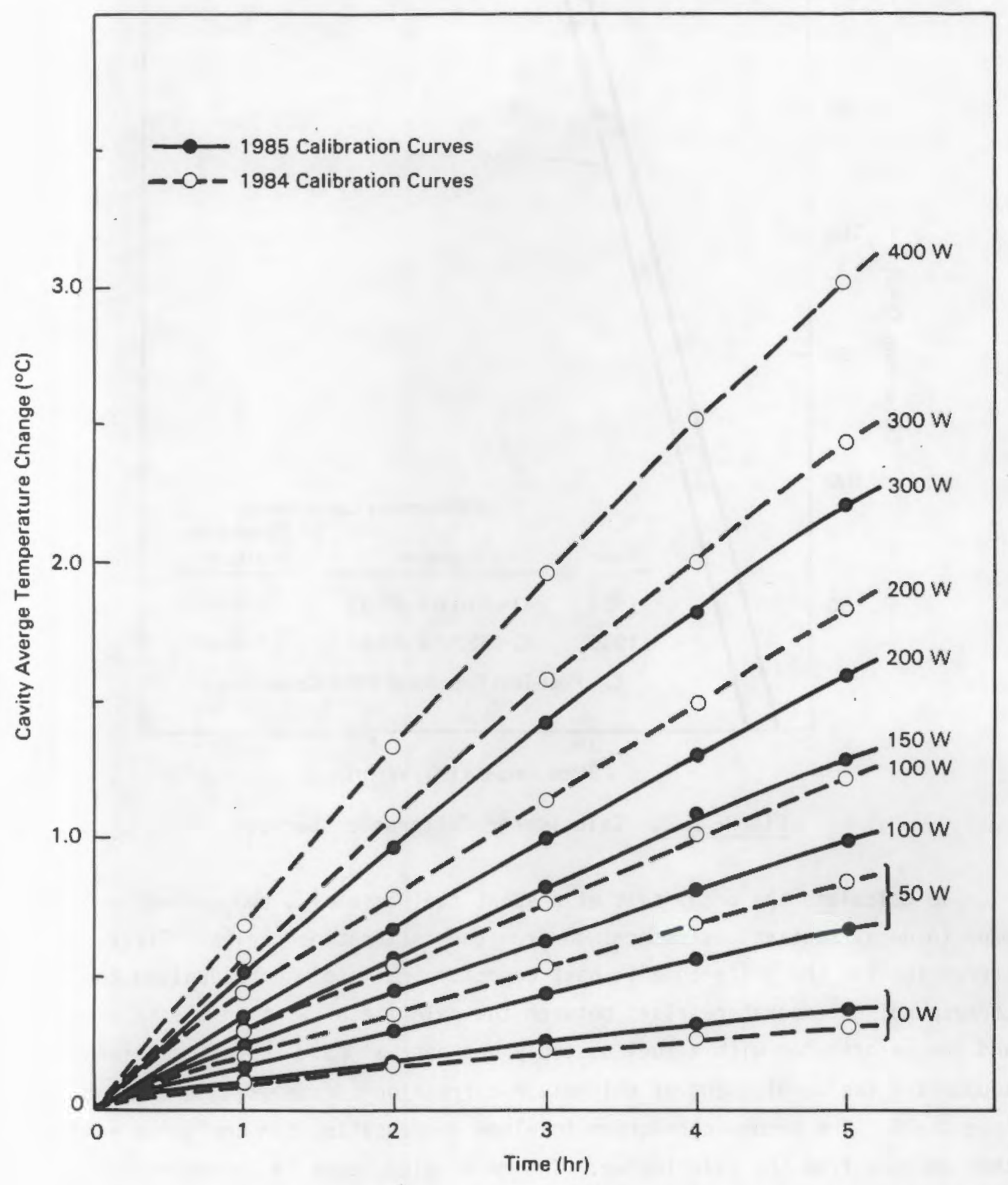

FIGURE 4.2. Calorimeter Time-Versus-Temperature Calibration Curves 


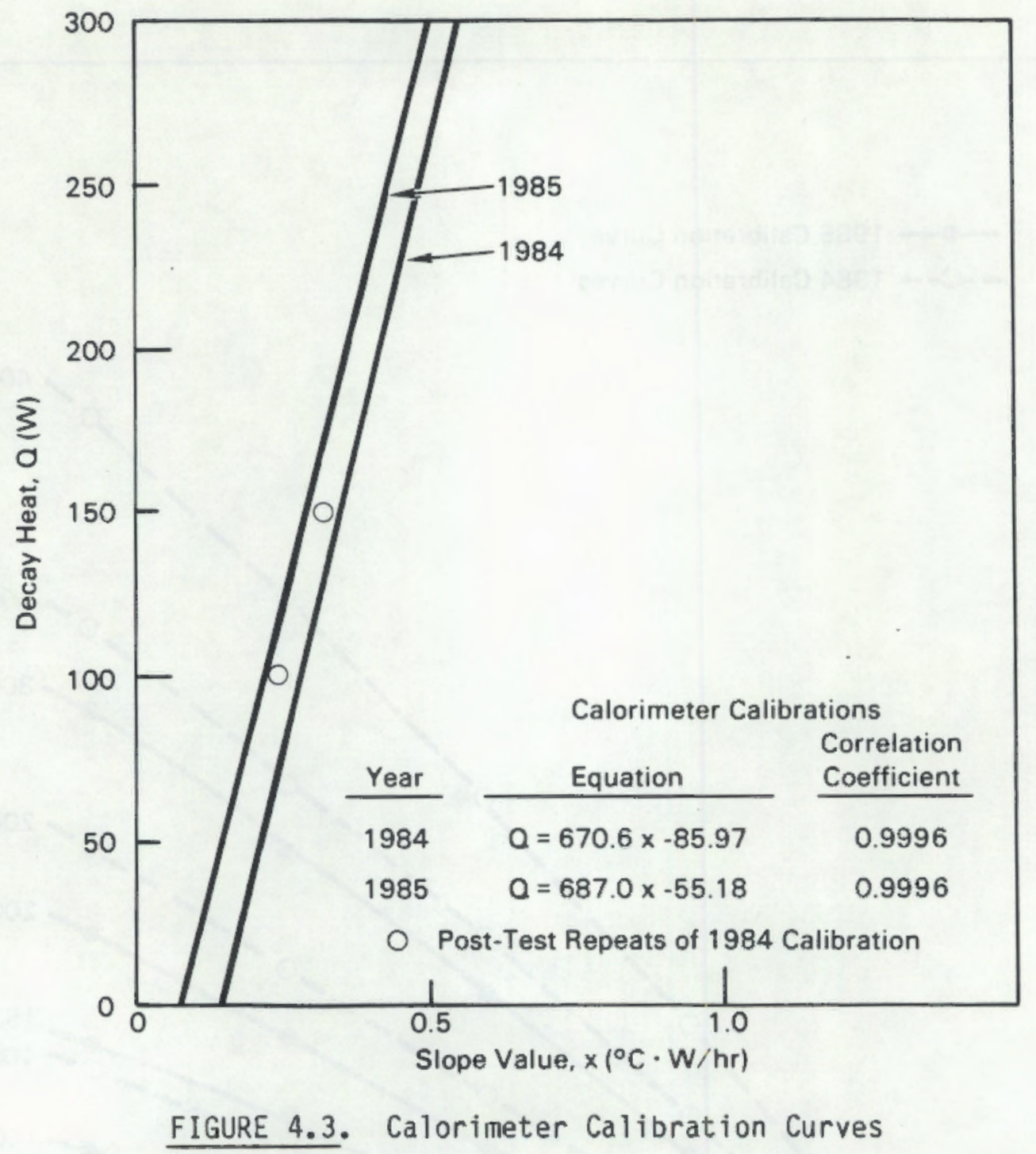

To calculate the decay heat of a spent fuel assembly, two corrections were made to decay heat values determined from the calibration curves. First, a correction for the difference in heat capacity (ratio of heat supplied to corresponding temperature rise) between the calorimeter with an electric heater and the calorimeter with a fuel assembly was determined. The calculations supporting the development of this minor correction factor $(<2 \%)$ are shown in Appendix A. The second correction involves compensating for the gamma energy that escapes from the calorimeter. The methodology used in determining the correction factor was developed in 1981 during initial calorimetry work for DOE (Judson et al. 1982), and then modified based upon measurements of the actual 
TABLE 4.1. Calorimeter Calibration Data

\begin{tabular}{|c|c|c|c|c|}
\hline $\begin{array}{c}\text { Date } \\
\text { Calibration } \\
\text { Run } \\
\end{array}$ & $\begin{array}{c}\text { Design } \\
\text { Power, W }\end{array}$ & $\begin{array}{l}\text { Measured (a) } \\
\text { Power, } W \\
\end{array}$ & Slope Value & $\begin{array}{c}\text { Index of } \\
\text { Determination } \\
\end{array}$ \\
\hline \multicolumn{5}{|l|}{1984 Method } \\
\hline $10 / 16 / 84$ & 0 & 0.0 & 0.156464 & 0.99959 \\
\hline $10 / 15 / 84$ & 50 & 49.2 & 0.352357 & 0.99996 \\
\hline $10 / 14 / 84$ & 100 & 99.7 & 0.522143 & 0.999984 \\
\hline $09 / 20 / 85$ (b) & 100 & 99.4 & 0.43786 & 0.99998 \\
\hline $09 / 19 / 85^{(b)}$ & 150 & 151.8 & 0.58150 & 0.99997 \\
\hline $10 / 13 / 84$ & 200 & 199.6 & 0.765893 & 0.999998 \\
\hline $10 / 15 / 84$ & 200 & 199.7 & 0.758893 & 0.999995 \\
\hline $10 / 14 / 85$ & 300 & 298.8 & 1.028286 & 0.999993 \\
\hline $10 / 13 / 84$ & 400 & 398.9 & 1.291536 & 0.9999999 \\
\hline
\end{tabular}

1985 Method

$\begin{array}{lrrll}09 / 15 / 85 & 0 & 0.0 & 0.19643 & 0.96554 \\ 09 / 18 / 85 & 0 & 0.0 & 0.16375 & 0.99970 \\ 09 / 16 / 85 & 50 & 52.9 & 0.28025 & 0.99995 \\ 09 / 17 / 85 & 50 & 50.2 & 0.27721 & 0.99995 \\ 09 / 18 / 85 & 50 & 50.3 & 0.27486 & 0.99985 \\ 09 / 10 / 85 & 100 & 98.5 & 0.41061 & 0.99989 \\ 09 / 14 / 85 & 100 & 100.6 & 0.40332 & 0.99996 \\ 09 / 06 / 85 & 150 & 149.2 & 0.53850 & 0.99998 \\ 09 / 15 / 85 & 150 & 149.0 & 0.54243 & 0.99999 \\ 09 / 05 / 85 & 200 & 199.6 & 0.65496 & 0.99998 \\ 09 / 06 / 85 & 300 & 300.4 & 0.93400 & 0.99993\end{array}$

(a) Actual watts are 5-hour averages, corrected for power loss in lines to calibration heater.

(b) Check on 1984 calibration. 
amount of absorption that occurred in the outer wall of the calorimeter (Mckinnon et al. 1985). The specifics relating to the development of this correction factor $(<12 \%)$ are contained in Appendix A.

Table 4.2 is a summary of the calorimetry decay heat data. A more complete listing of the data is found in Appendix A. Repeatability of the data using the 1985 method can be assessed from the runs made on fuel assembly MT133. The repeatability of these measurements corrected for decay rate (i.e., a same-day measurement comparison) is indicated by a standard deviation of $\pm 1.7 \mathrm{~W}$. The repeatability of the data collected using the 1984 method of operation is no better than $\pm 15 \mathrm{~W}$, based on repeat measurements on assemblies MT123, MT133, and MT228. The reason the 1985 method of calorimeter operation gave better repeatability than the 1984 method was not obvious. Its evaluation was outside with the scope of this study.

TABLE 4.2. Monticello Spent Fuel Assembly Calorimetry Results

\begin{tabular}{|c|c|c|c|c|}
\hline \multirow{2}{*}{$\begin{array}{l}\text { Assembly } \\
\text { ID } \\
\end{array}$} & \multicolumn{2}{|c|}{ 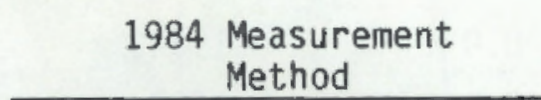 } & \multicolumn{2}{|c|}{$\begin{array}{l}1985 \text { Measurement } \\
\text { Method }\end{array}$} \\
\hline & Date & Decay Heat, $W$ & Date & Decay Heat, $W$ \\
\hline MT116 & $06 / 10 / 85$ & 114.9 & $08 / 27 / 85$ & 119.6 \\
\hline \multirow[t]{3}{*}{ MT123 } & $06 / 05 / 85$ & 66.8 & $08 / 27 / 85$ & 97.2 \\
\hline & $06 / 08 / 85$ & 95.3 & & \\
\hline & $06 / 11 / 85$ & 65.9 & & \\
\hline \multirow[t]{8}{*}{ MT133 } & $05 / 29 / 85$ & 152.6 & $06 / 13 / 85$ & 146.0 \\
\hline & $06 / 06 / 85$ & 129.0 & $06 / 13 / 85$ & 145.4 \\
\hline & $06 / 09 / 85$ & 154.8 & $08 / 20 / 85$ & 146.0 \\
\hline & $06 / 12 / 85$ & 106.7 & $08 / 21 / 85$ & 146.8 \\
\hline & & & $08 / 29 / 85$ & 149.9 \\
\hline & & & $08 / 30 / 85$ & 144.7 \\
\hline & & & $08 / 31 / 85$ & 147.0 \\
\hline & & & $09 / 01 / 85$ & 147.8 \\
\hline MT190 & $06 / 08 / 85$ & 99.2 & $08 / 28 / 85$ & 107.6 \\
\hline \multirow[t]{3}{*}{ MT228 } & $05 / 30 / 85$ & 101.0 & $08 / 20 / 85$ & 90.3 \\
\hline & $06 / 07 / 85$ & 71.2 & & \\
\hline & $06 / 11 / 85$ & 76.4 & & \\
\hline MT264 & $06 / 05 / 85$ & 46.1 & $08 / 28 / 85$ & 76.2 \\
\hline
\end{tabular}




\subsection{ION-1 SYSTEM AND AXIAL RADIATION DATA}

Gamma and neutron axial profile data were taken on each of the fuel assemblies subjected to calorimetry. The LANL portable spent-fuel detector, known as the ION-1/fork measurement system, was used at GE-MO to make these radiation readings. Basically, the LANL ION-1 system shown in Figure 4.4 consists of underwater sensors and an above-water electronics unit that monitors and displays the measured radiation. The underwater unit consists of two cylindrical forked tines made of polyethylene. Each tine contains a cadmium-covered fission chamber, a noncovered fission chamber, and an ion chamber. The opening between the tines was about $1.3 \mathrm{~cm}(0.5 \mathrm{in.)}$ greater than the width of a

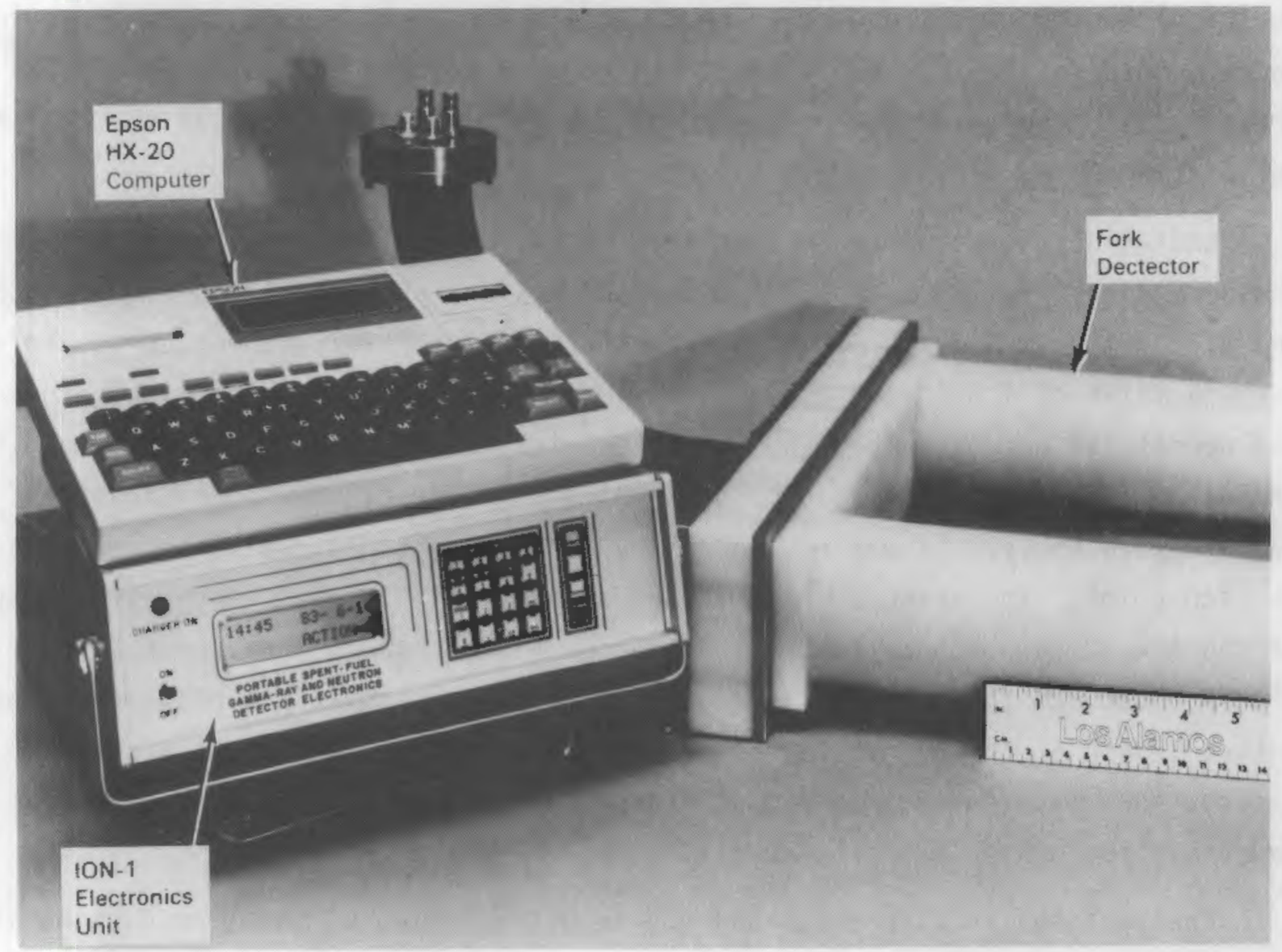

FIGURE 4.4. LoS Alamos ION-1 Spent Fuel Radiation Measurement Equipment Source: Mckinnon et al. (1985, p. 3-12) 
typical $7 \times 7$ BWR spent fuel assembly. The above-water electronics unit provides hard copies of the data output and has a magnetic tape interface.

In preparation for using the ION-1 at GE-MO, various preliminary neutron and gamma measurements were taken to test the equipment and to determine the detector response for wel1-defined source-detector configurations. Neutron measurements were made in water with a ${ }^{252} \mathrm{Cf}$ source of known strength centered between the tines. For a lower-level discriminator setting of 25 on the ION-1, the efficiency for the cadmium-covered detector was $2.68 \times 10^{-5}$; for the bare detectors the efficiency was $5.2 \times 10^{-5}$. The ion chambers were checked using a ${ }^{60}$ Co source in air. The average linear response of the two ion chambers is $70 \mathrm{R} / \mathrm{hr}$ per ION-1 reading. These measurements verified that the equipment was functioning properly. However, direct correlations between the source measurements and actual fuel assembly measurements were not within the scope of this project. Such correlations may be developed by performing detailed neutronics calculations.

Radiation was measured at nine axial locations on each fuel assembly. These readings are 1 isted in Tables 4.3 and 4.4 and are graphed in Figures 4.5 and 4.6. Figures 4.7 and 4.8 show the effect of normalizing these curves to an average value of 1 over the active fuel length and then taking an average of the normalized curves. The readings taken with the ION-1 were intended to give radiation information sufficient to establish axial decay heat profiles for each fuel assembly. It was not necessary to have absolute radiation readings at each point. The measurements made on assembly MT133 show the repeatability of the ION-1 measurements to be within about $\pm 1 \%$ for gamma measurements and within about $\pm 2 \%$ for the neutron measurements for a significant portion of the active length of the assemblies. This repeatability is consistent with observations made during a previous study (McKinnon et al. 1985) where the repeatability was observed to be $\pm 1 \%$.

The profiles in Figure 4.5 and 4.6 show the effect of local conditions in the reactor on the profiles. It is apparent from these profiles that localized conditions (proximity to control rods, void fracture, and total burnup) do affect the gamma and neutron profiles. Figures 4.7 and 4.8 give a representative average profile for the six fuel assemblies. 
TABLE 4.3. Monticello Spent Fuel Axial Gamma Radiation Profiles

\begin{tabular}{|c|c|c|c|c|c|c|c|c|c|}
\hline \multirow{2}{*}{$\begin{array}{c}\text { Assembly } \\
\text { ID } \\
\end{array}$} & \multicolumn{9}{|c|}{ Elevation, m } \\
\hline & $0.19(\mathrm{a})$ & 0.55 & 1.06 & 1.57 & 2.47 & 2.98 & 3.49 & 3.85 & $4.19^{(\mathrm{b})}$ \\
\hline MT123 & 5.3 & 43.5 & 71.1 & 73.0 & 70.2 & 67.1 & 49.3 & 24.1 & 5.8 \\
\hline MT116 & 19.3 & 54.4 & 87.5 & 92.6 & 92.6 & 92.6 & 73.9 & 37.3 & 3.6 \\
\hline MT133 & 27.1 & 66.6 & 107.8 & 115.1 & 111.7 & 113.2 & 93.0 & 46.6 & 10.3 \\
\hline MT133 & 27.1 & 65.8 & 106.5 & 114.0 & 111.1 & 112.3 & 92.6 & 46.5 & 10.2 \\
\hline MT133 & 28.1 & 67.5 & 107.3 & 113.6 & 110.4 & 111.1 & 90.3 & 44.9 & 10.0 \\
\hline MT190 & 10.1 & 47.4 & 77.7 & 80.6 & 82.2 & 85.2 & 72.8 & 37.4 & 5.6 \\
\hline MT228 & 16.6 & 43.5 & 66.1 & 66.6 & 62.4 & 60.2 & 46.9 & 23.2 & 4.2 \\
\hline MT264 & 11.4 & 32.2 & 51.1 & 54.0 & 53.0 & 50.7 & 39.3 & 20.0 & 3.1 \\
\hline
\end{tabular}

(a) Elevation of lower tie plate.

(b) Elevation of upper tie plate.

TABLE 4.4. Monticello Spent Fuel Axial Neutron Radiation Profiles

\begin{tabular}{|c|c|c|c|c|c|c|c|c|c|}
\hline \multirow{2}{*}{$\begin{array}{l}\text { Assembly } \\
\text { ID } \\
\end{array}$} & \multicolumn{9}{|c|}{ Elevation, $m$} \\
\hline & $0.19(a)$ & 0.55 & 1.06 & 1.57 & 2.47 & 2.98 & 3.49 & 3.85 & $4.19(b)$ \\
\hline MT123 & 0.0 & 2.5 & 9.6 & 12.4 & 13.9 & 10.2 & 4.7 & 0.8 & 0.0 \\
\hline MTl16 & 0.1 & 2.8 & 16.9 & 24.6 & 30.8 & 27.2 & 16.0 & 2.0 & 0.0 \\
\hline MT133 & 0.0 & 8.0 & 35.2 & 48.3 & 52.1 & 53.2 & 28.9 & 4.8 & 0.0 \\
\hline MT133 & 0.1 & 6.4 & 35.3 & 46.3 & 53.7 & 55.2 & 32.9 & 4.9 & 0.0 \\
\hline MT133 & 0.0 & 8.9 & 36.8 & 49.6 & 50.9 & 55.3 & 29.1 & 4.1 & 0.0 \\
\hline MT190 & 0.0 & 1.3 & 10.2 & 12.2 & 14.4 & 17.8 & 10.7 & 2.9 & 0.0 \\
\hline MT228 & 0.0 & 0.6 & 5.2 & 5.9 & 6.3 & 4.3 & 2.6 & 0.6 & 0.0 \\
\hline MT264 & 0.1 & 0.8 & 2.3 & 2.7 & 3.1 & 2.7 & 1.4 & 0.2 & 0.0 \\
\hline
\end{tabular}

(a) Elevation of lower tie plate.

(b) Elevation of upper tie plate. 


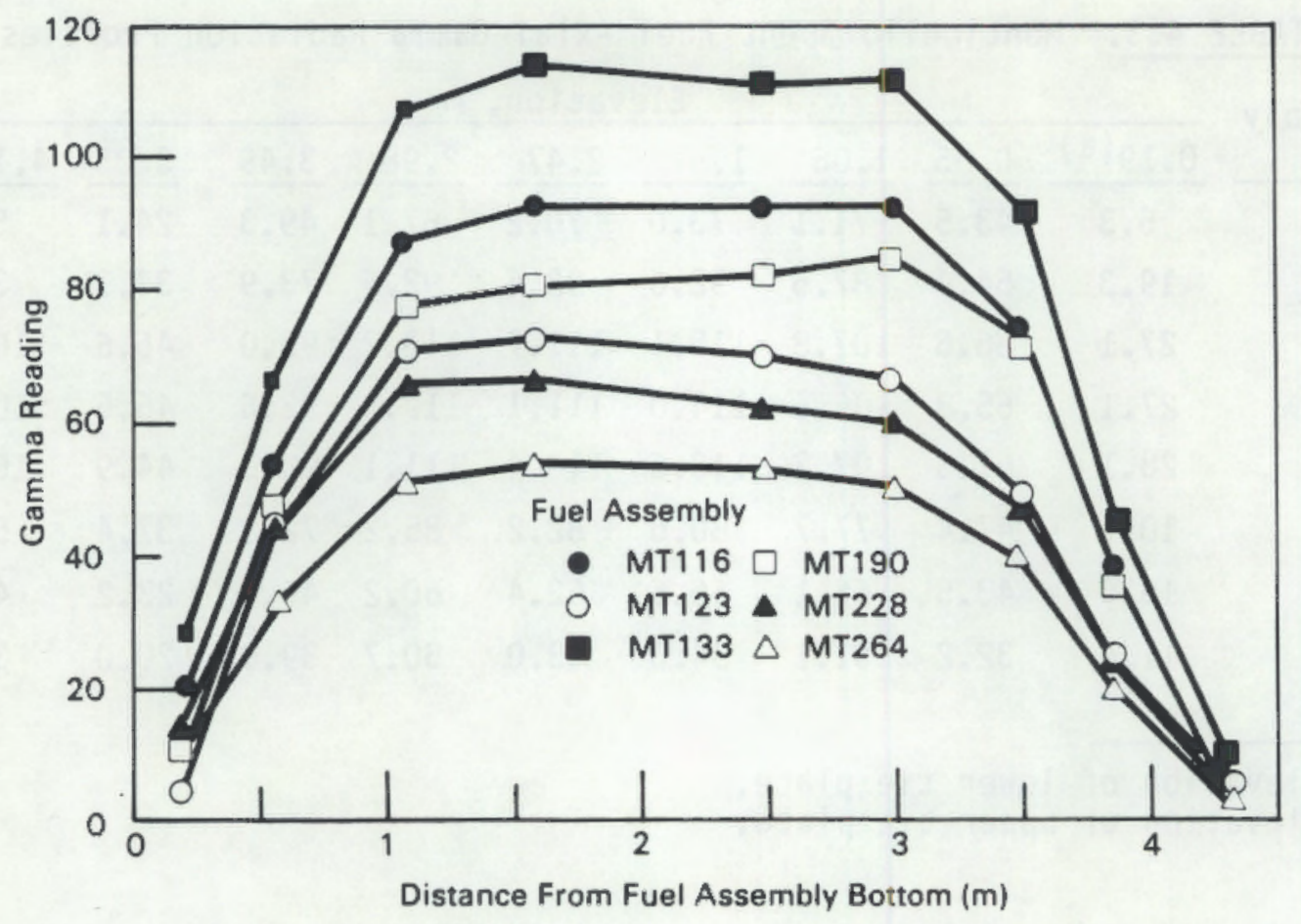

FIGURE 4.5. Monticello Spent Fuel Axial Gamma Profiles

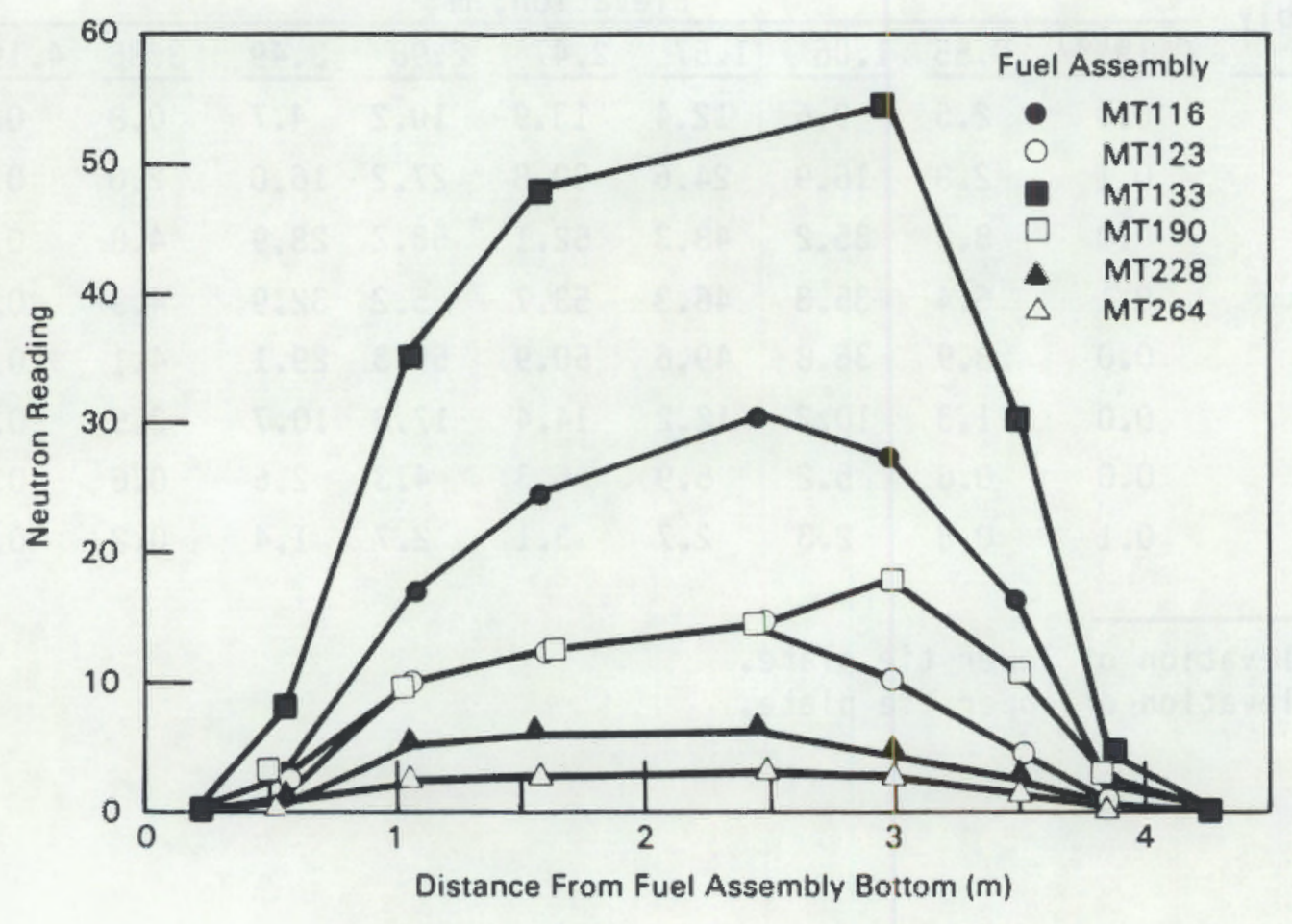

FIGURE 4.6. Monticello Spent Fuel Axial Neutron Profiles 


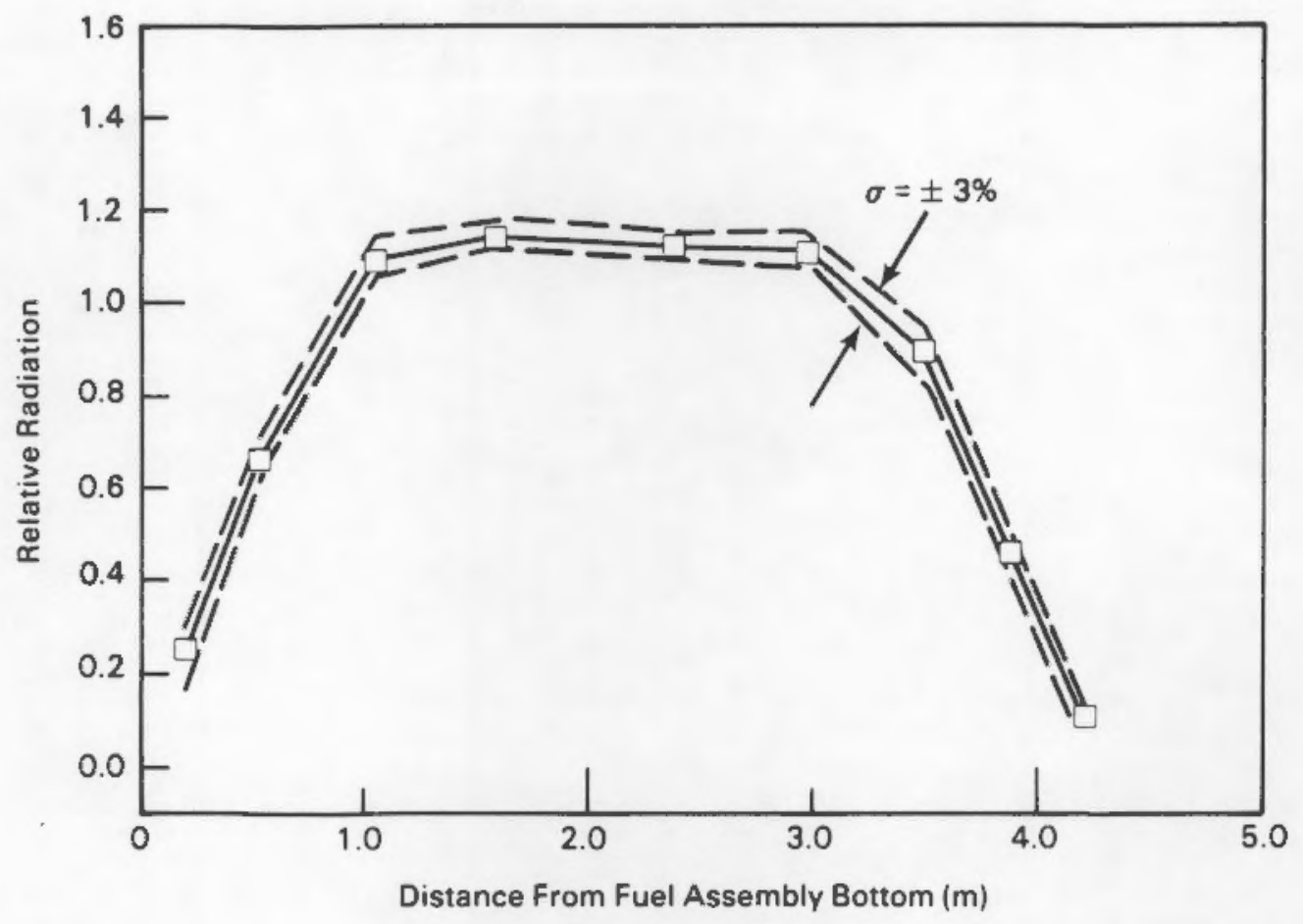

FIGURE 4.7. Monticello Spent Fuel Normalized Gamma Axial Radiation Profile

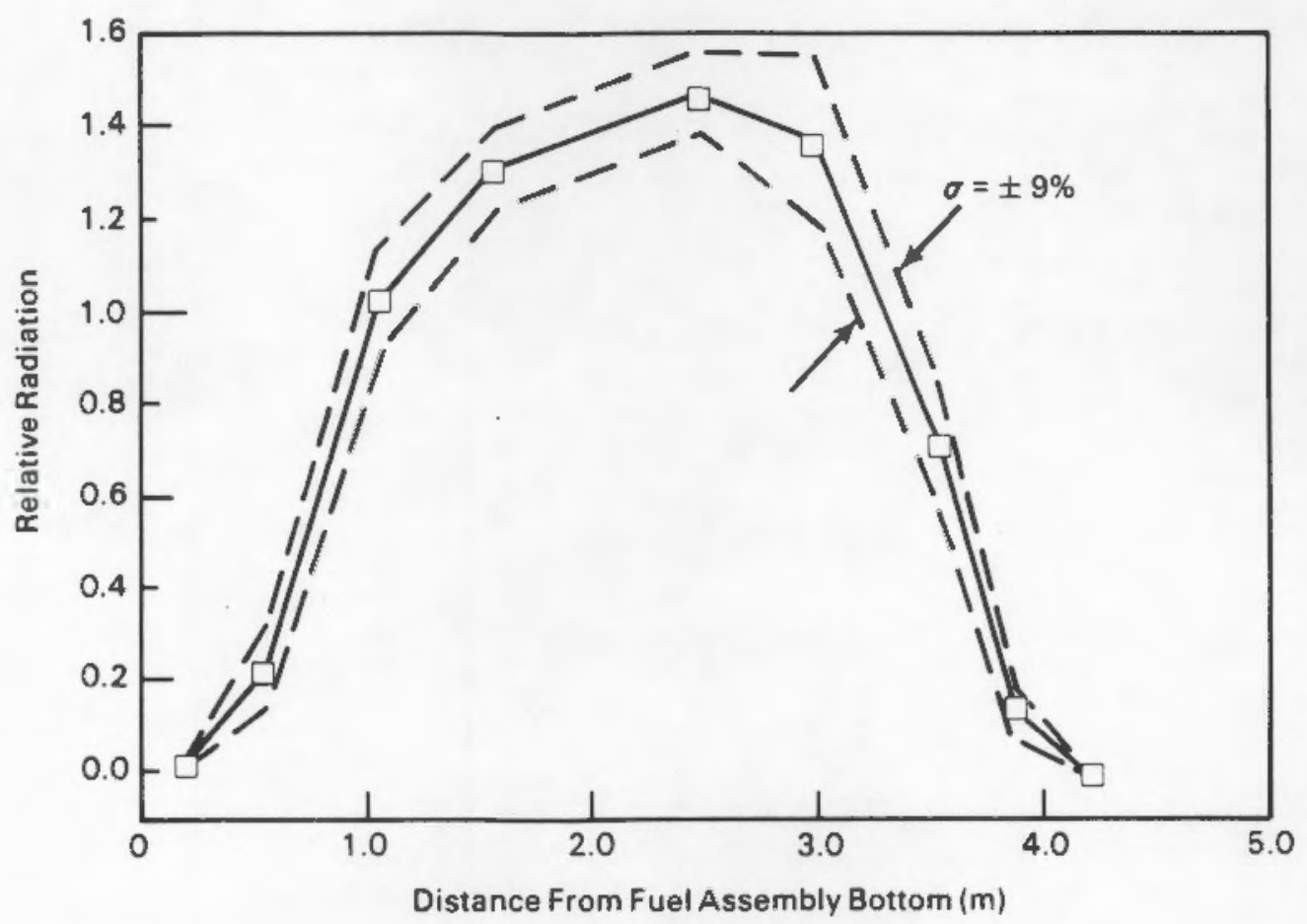

FIGURE 4.8. Monticello Spent Fuel Normalized Neutron Axial Radiation Profile 



\subsection{DECAY HEAT ANALYSIS AND DATA COMPARISONS}

The pre-calorimetry decay heat analysis is discussed in this section. First, the ORIGEN2 computer code is described. Next, the input to the code is identified. Last, predictions of decay heat and axial radiation profiles are compared to actual measurements.

\subsection{ORIGEN2 COMPUTER CODE}

A standard version of the ORIGEN2 code (Croff 1980a,b) was used to predict the decay heat rates of six Monticello BWR spent fuel assemblies. The ORIGEN2 code is widely used in the nuclear industry to predict decay heat rates of spent fuel assemblies. It is a general purpose burnup and decay code that features extensive data libraries containing information on over 1200 nuclides. The code can be used to perform transmutation calculations in steps of constant power or constant neutron flux level. The resulting nuclide concentrations can be decayed with user-specified time intervals. Output options are available for decay heat rate as well as spent fuel compositions and radioactivity.

Before the ORIGEN2 code was used to predict the decay heat rates of the selected fuel assemblies, code results from a standard problem were compared with results from another standard version of the code run on another computer. The comparison was performed to ensure that the predictions are what would be expected from the code as it would be received from the Oak Ridge National Laboratory (ORNL) Radiation Shielding Information Center.

ORIGEN2 results are based on a large library of one energy group cross sections of the nuclides. These cross sections are the result of extensive calculations starting with a numerical description of the cross section of each isotope as a function of neutron energy. The basic cross sections are averaged over the energy range of $0 \mathrm{eV}$ to $17 \mathrm{MeV}$ using a computed neutron energy spectrum. The calculation of the neutron spectrum is done with a composition appropriate to a specific reactor core design and operating condition. The user is provided with various data libraries, each representing a reactor type, core loading, and operating condition. There is one BWR cross section library 
for a ${ }^{235} \mathrm{U}$ enriched core; this actinide library has the numerical designation 252. Associated with it are activation product library 251 and fission product library 253, which were generated using the same neutron spectrum as was used to generate library 252.

A special concern in making decay heat rate predictions with ORIGEN2 for BWR fuel, as opposed to PWR fuel, is the effect of steam voids on the neutron spectrum. The BWR core operating environment contains appreciable steam voids. The ratio of plutonium to uranium fissions and the actinide composition at a given burnup are influenced by differences in the neutron spectrum. Assembly decay heat rates are determined by different fission product yields for uranium and plutonium and by the mix of actinide isotopes in the spent fuel. A series of calculations was performed to evaluate the sensitivity of decay heat rates to variations of core steam void fractions. A version of the LEOPARD code (Barry 1963) was used to calculate the effect of unit cell steam voiding on the one group spectrum-averaged cross sections of the isotope responsible for most of the decay heat. The change in the spectrum-averaged cross section at a given void fraction relative to the ORIGEN2 library default void fraction of $31.6 \%$ was determined for a range of void fractions. These relative change factors were used to alter the cross section of ORIGEN2 library 252 via code input for a series of ORIGEN2 cases, each representing a specific core steam void fraction in the range of $0 \%$ to $90 \%$. As a result of these sensitivity calculations, it was found that core void variations of $0 \%$ to $90 \%$ can cause the decay heat rate to vary by $11 \%$ to $30 \%$, depending on the time out of reactor.

The spectrum used in computing libraries 251, 252, and 253 was calculated assuming a BWR -6 assembly ( $8 \times 8$ rod array) at $31.6 \%$ core average steam void fraction (Croff et al. 1978). The Monticello fuel assemblies used in this study are of the earlier $7 \times 7$ design. The void fraction that has the same hydrogen-to-uranium $(H / U)$ ratio as the $31.6 \%$ used in calculating the ORIGEN2 library is $36 \%$ for the $7 \times 7$ rod design. The H/U ratio is a reasonable basis to use to determine the equivalent void fraction. It is a good measure of the hardness of the neutron spectrum because the relative moderation and absorption rates are determined by the $\mathrm{H} / \mathrm{U}$ ratio. The Monticello BWR assemblies had 
operating void fractions of $39 \%$ to $40 \%$ void, which is close to the $36 \%$ equivalent void fraction of the library. Therefore, no corrections for void fraction were made.

\subsection{ORIGEN2 INPUT SPECIFICATIONS}

Summaries of Monticello fuel assembly design and burnup data used as input to ORIGEN2 were presented in Tables 3.1 and 3.2 in Section 3.0. Neither table gives the assemblies' structural material content. These materials contribute to the decay heat from neutron activation. Because the fraction of decay heat from neutron activation of assembly structural materials is less than $5 \%$ of the total decay heat, generic values were used. These values are given in the ORNL document (Croff et al. 1978) that describes the makeup of the ORIGEN2 BWR library. The two elements contributing the largest share of activation heating are cobalt and gadolinium. A value of $1573 \mathrm{ppm}$ was assumed for the gadolinium concentration in the uranium fuel. The cobalt content of the 304 stainless steel was assumed to be $800 \mathrm{ppm}$. The Zircaloy-2 cladding was assumed to contain 10 ppm cobalt, and the uranium oxide was assumed to contain 1 ppm cobalt.

All assemblies were initially enriched to $2.25 \mathrm{wt} \%{ }^{235} \mathrm{U}$ averaged over all rods in each assembly. Sensitivity studies were conducted (McKinnon et al. 1985) using ORIGEN2 with different enrichments to ensure that calculated decay heat rates based on single average assembly enrichments closely approximated average decay heat rates from ORIGEN2 based on individual rod enrichments in the assemblies.

The Monticello reactor power history for the first four operating eycles is shown in Figure 5.1. The specific reactor powers (tabulated values are in Appendix B) are based on a design core power of $18.2 \mathrm{MW} / \mathrm{MTU}$ when the reactor is operated at its full thermal power of $1670 \mathrm{MWt}$.

Power histories for the assemblies were determined from burnup histories shown in Table 3.2, Section 3.0, and from the reactor power history shown in Figure 5.1. Assembly power histories within a reactor operating cycle were calculated by multiplying the ratio of incremental burnup for the cycle (Table 3.2 ) to the core average incremental burnup for that cycle by the core 


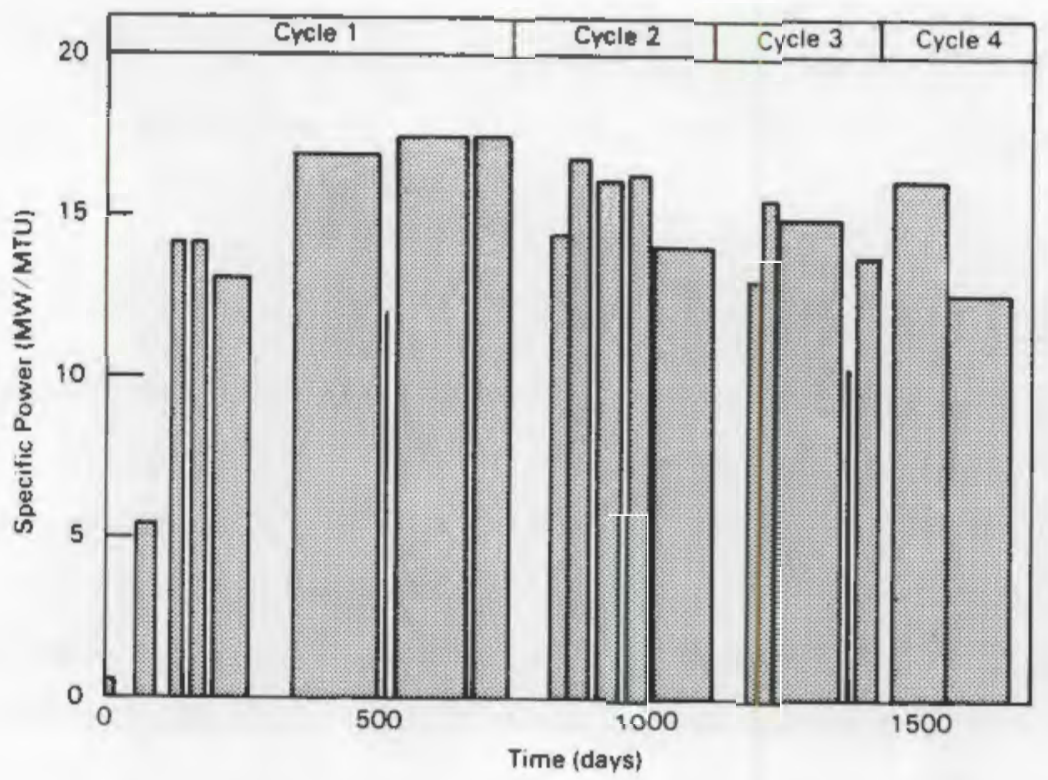

FIGURE 5.1. Monticello Reactor Operating History (Cycles 1 through 4)

averaged power history (Figure 5.1). A resulting typical assembly-specific power history used as input to ORIGEN2 is shown in Figure 5.2 for assembly MT133. The complete input file for the ORIGEN2 prediction of the decay heat of MT133 is presented in Appendix B.

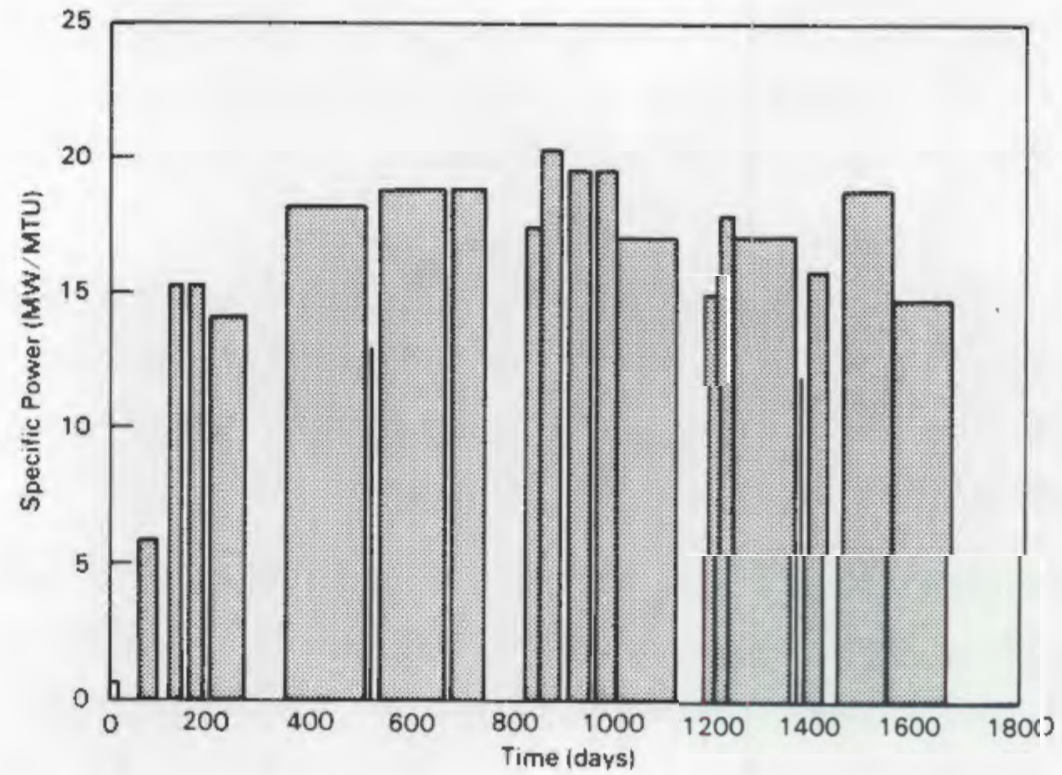

FIGURE 5.2. Monticello Assembly MT133 Specific Power History 


\subsection{ORIGEN2 PREDICTIONS COMPARED TO DATA}

Predictions of both the magnitude of assembly decay heat rates and axial decay heat profiles are compared to experimental data in the following subsections. Predictions and decay heat data previously obtained (Mckinnon et al. 1985, 1986) for the Dresden and Cooper BWR spent fuel assemblies are included for completeness.

\subsubsection{Decay Heat Rates}

Measured values of decay heat generation rates and ORIGEN2 pre-calorimetry predictions are shown in Table 5.1 for every run made with the six Monticello spent fuel assemblies. Table 5.1 contains predictions made using final burnup values based on the Cycle Sumnary reports and Form 30 reports. Plots of the information contained in Table 5.1 are shown in Figures 5.3, 5.4, and 5.5. The scatter in the data shown in Figure 5.3 prompted an investigation into the reason for the large differences among repeat measurements on the same fuel assembly; see the measured decay heat values in Table 5.1 for assemblies MT123, MT133, and MT 228. The investigation did not identify the reason for the large differences among repeat measurements but did suggest a small change in the operation of the calorimeter that resulted in better measurement repeatability. The new method of operation, described in Section 4.1, prompted a recalibration of the calorimeter using the new (1985) method of operation.

All the data taken using the 1985 method of operation is shown in Figure 5.4. The correlation between the predictions and data is much more apparent in Figure 5.4 than it is in Figure 5.3. Figure 5.4 also shows that there would be much less scatter from the best fit straight line for predictions based on the Cycle Summary final burnups than for predictions based on Form 30 final burnups. The EPRI calorimetry study (McKinnon et al. 1985) and the calorimetry done in conjunction with BWR cask performance testing (Mckinnon et al. 1986) also showed that the predictions based on Cycle Summary total burnups have a tighter fit to the measured data than do the Form 30 total burnup-based predictions. 
TABLE 5.1. Monticello Spent Fuel Assembly Calorimetry Results

\begin{tabular}{|c|c|c|c|c|c|c|c|c|}
\hline \multirow[b]{2}{*}{$\begin{array}{c}\text { Assembly } \\
\text { ID }\end{array}$} & \multicolumn{4}{|c|}{1984 Method } & \multicolumn{4}{|c|}{1985 Method } \\
\hline & $\begin{array}{c}\text { Measurement } \\
\text { Date } \\
\end{array}$ & $\begin{array}{l}\text { Measured } \\
\text { Decay } \\
\text { Heat, W }\end{array}$ & $\begin{array}{c}\text { Predicted } \\
\text { Form } 30, \\
W\end{array}$ & $\begin{array}{l}\text { Decay Heat } \\
\text { Cycle } \\
\text { Summary, w }\end{array}$ & $\begin{array}{c}\text { Measurement } \\
\text { Date } \\
\end{array}$ & $\begin{array}{l}\text { Measured } \\
\text { Decay } \\
\text { Heat, W }\end{array}$ & $\begin{array}{c}\text { Predicted } \\
\text { Form } 30, \\
W \\
\end{array}$ & $\begin{array}{c}\text { Decay Heat } \\
\text { Cycle } \\
\text { Summary, } W\end{array}$ \\
\hline MT123 & $06 / 05 / 85$ & 66.8 & 73.2 & 79.5 & $08 / 27 / 85$ & 97.2 & 72.7 & 79.0 \\
\hline & $06 / 08 / 85$ & 95.3 & 73.2 & 79.5 & & & & \\
\hline MT133 & $05 / 29 / 85$ & 152.6 & 124.3 & 125.4 & $06 / 13 / 85$ & 146.0 & 124.2 & 125.3 \\
\hline & $06 / 06 / 85$ & 129.0 & 124.3 & 125.4 & $06 / 13 / 85$ & 145.4 & 124.2 & 125.3 \\
\hline & $06 / 09 / 85$ & 154.8 & 124.3 & 125.4 & $08 / 20 / 85$ & 146.0 & 123.3 & 124.4 \\
\hline & $06 / 12 / 85$ & 106.7 & 124.2 & 125.4 & $08 / 21 / 85$ & 146.8 & 123.3 & 124.4 \\
\hline & & & & & $09 / 01 / 85$ & 147.8 & 123.1 & 124.2 \\
\hline MT190 & $06 / 08 / 85$ & 99.2 & 88.7 & 89.7 & $08 / 28 / 85$ & 107.6 & 88.0 & 89.0 \\
\hline MT228 & $05 / 30 / 85$ & 101.0 & 70.7 & 73.3 & $08 / 20 / 85$ & 90.3 & 70.2 & 72.7 \\
\hline & $06 / 07 / 85$ & 71.2 & 70.7 & 73.2 & & & & \\
\hline & $06 / 11 / 85$ & 76.4 & 70.6 & 73.2 & & & & \\
\hline MT264 & $06 / 05 / 85$ & 46.1 & 52.6 & 57.9 & $08 / 28 / 85$ & 76.2 & 52.2 & 57.5 \\
\hline
\end{tabular}




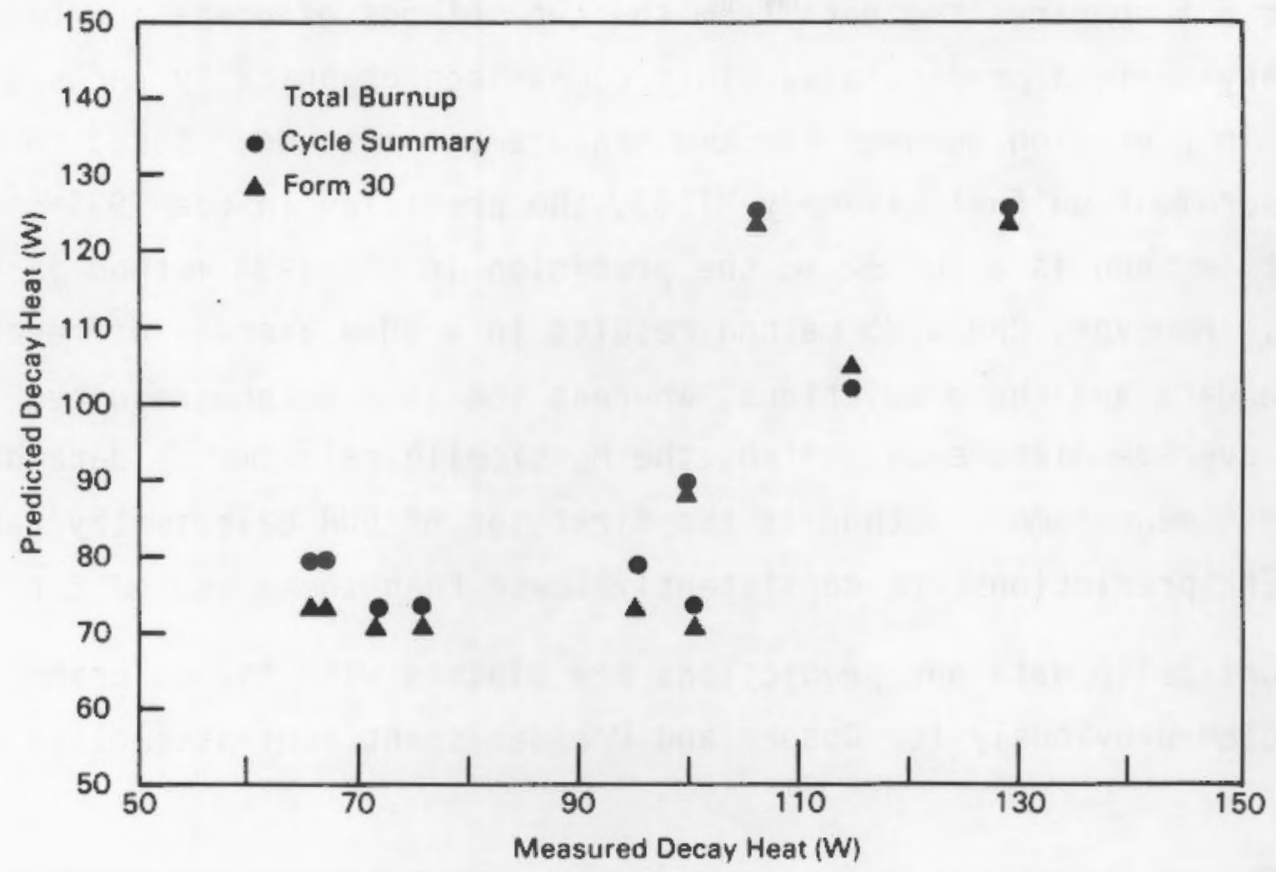

FIGURE 5.3. Predicted and Measured Monticello Spent Fuel Decay Heat Rates Obtained Using the 1984 Measurement Method

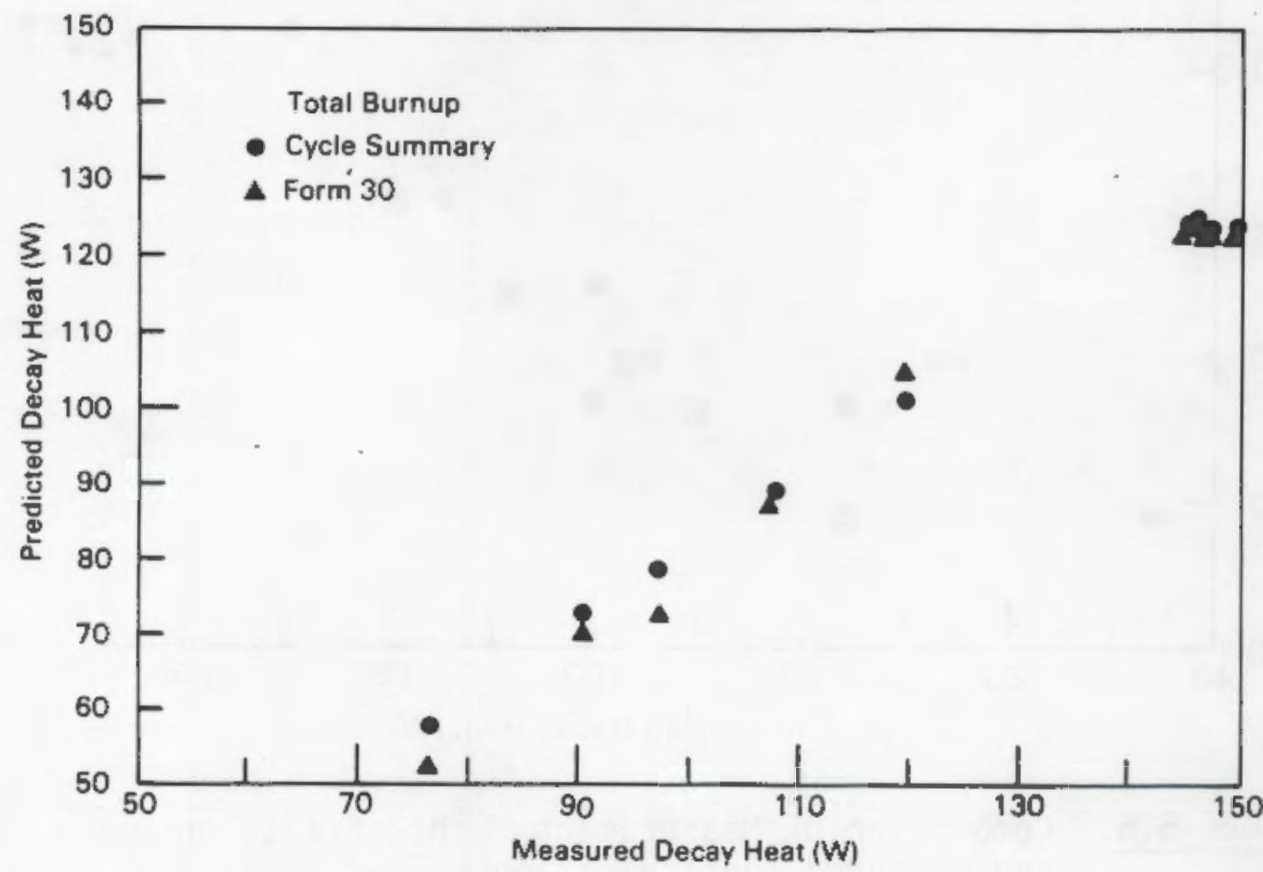

FIGURE 5.4. Predicted and Measured Monticello Spent Fuel Decay Heat Rates Obtained Using the 1985 Measurement Method 
Figure 5.5 compares the data from the two methods of operation based on Cycle Summary-derived predictions. This comparison graphically shows the difference in precision between the two measurement methods. Based on the repeat measurement on fuel assemb1y MT133, the precision in the 1985 measurements method is about $\pm 2 \mathrm{~W}$; the precision in the 1984 method is greater than $\pm 15 W$. However, the 1985 method results in a 20-W average difference between the data and the predictions, whereas the 1984 method resulted in less than a 4-W average difference. Also, the Monticello calorimetry data obtained from the 1985 measurement method is the first set of BWR calorimetry data in which ORIGEN2 predictions are consistently lower than the measured data.

The Monticello data and predictions are plotted with the calorimetry data collected previously for Cooper and Dresden spent fuel assemblies in

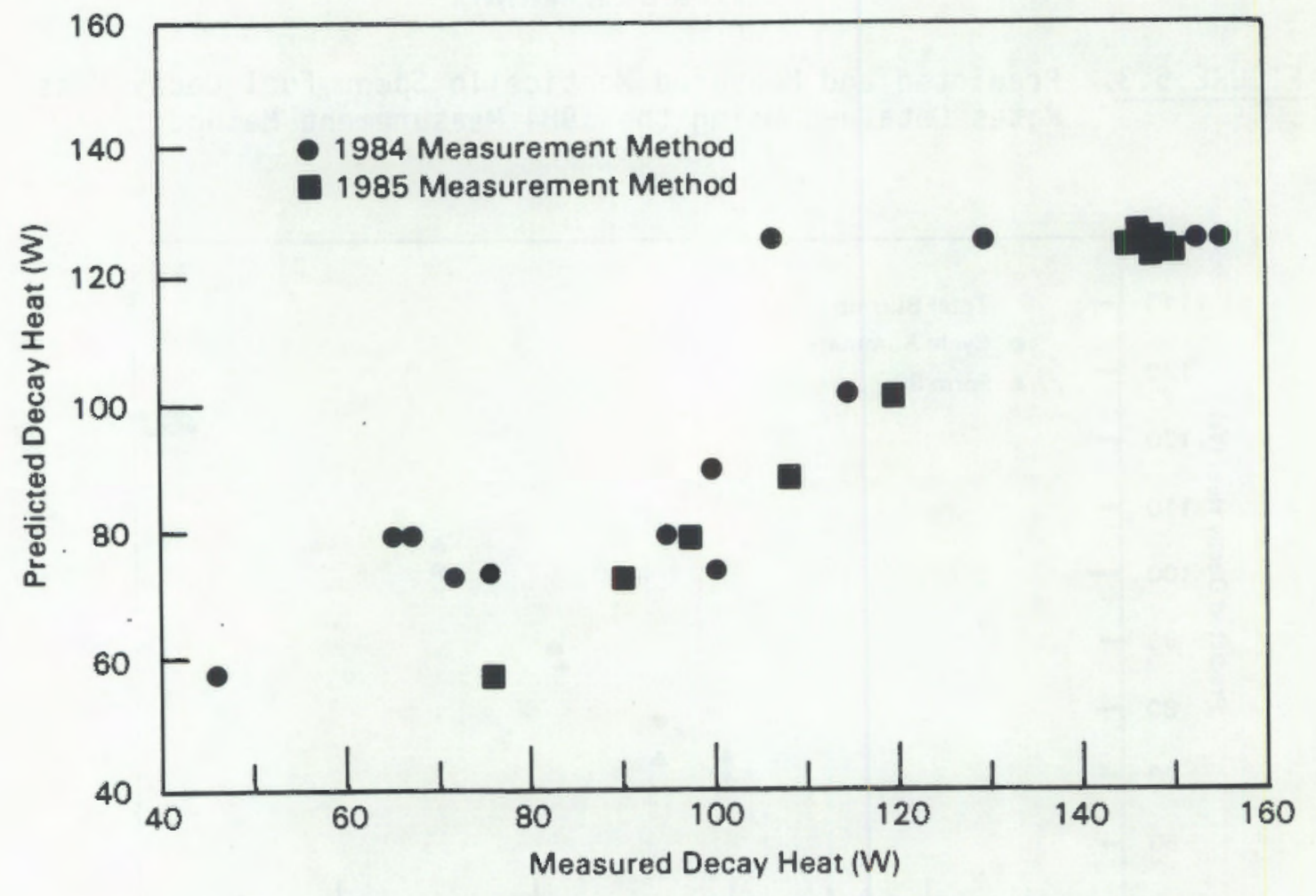

FIGURE 5.5. Comparison of Measurement Method Effect on Predicted and Measured Monticello Spent Fuel Decay Heat Rate 
Figure 5.6. Linear regression analysis was used to fit a straight line to the data shown in Figure 5.6. The equation of this line is

$$
\text { Measured decay heat }=\text { Predicted decay heat }-6
$$

The standard deviation of the data about the line is $\pm 14.3 \mathrm{~W}$. The -6 intercept is a result of the Monticello data obtained from the 1985 measurement method.

It seems strange that the curve representing the relationship between the Monticello predictions and data from the 1985 method would parallel the curve for the other data but be displaced from it, unless there is something in the prediction or measurement process that can introduce a constant that is independent of decay heat magnitude.

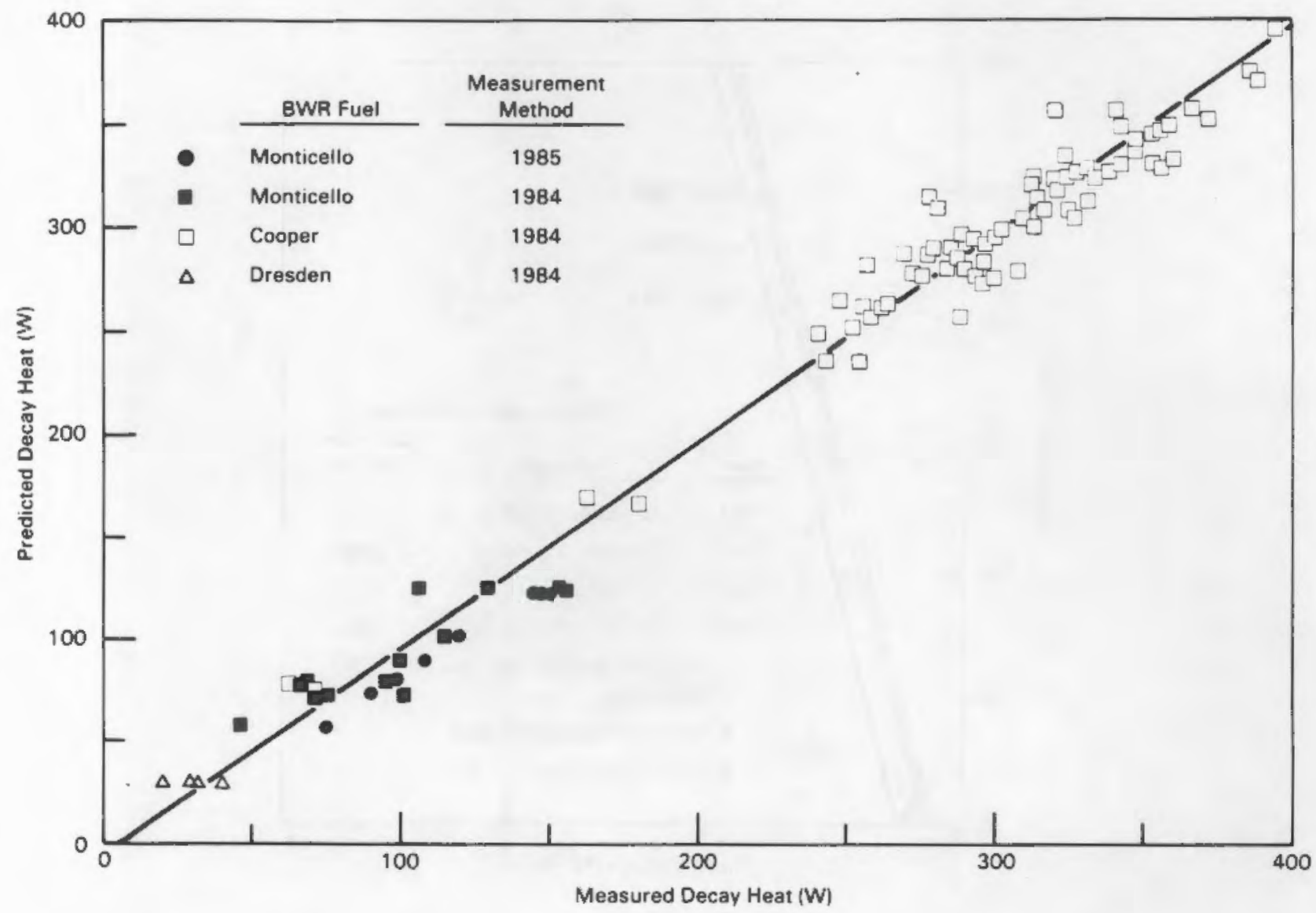

FIGURE 5.6. Predicted and Measured Decay Heat Rates for Dresden, Cooper, and Monticello Spent Fuel Assemblies 
This opportunity does exist in the measurement process where temperatures are recorded over a 5-hour period. The temperature-time curve is determined by using regression analysis to fit a curve to the data (Figure 4.2, Section 4.1). The slope of this curve at time $=$ zero is then entered into a calorimetry calibration curve of the form $y=m x+b$, where $x$ is the slope at time zero, $y$ is the decay heat, and $m$ and $b$ are constants determined from a best fit to the calibration data. If the constant $b$ were in error for some reason, then measured values would be displaced from their true values by a constant amount.

Figure 5.7 shows the calorimeter calibration curves that have been determined over the course of the calorimeter's existence (Judson et al. 1982; Mckinnon et al. 1985, 1986). It is interesting to note that the slope values for all of the curves vary by less than $\pm 2 \%$, whereas intercept values vary from

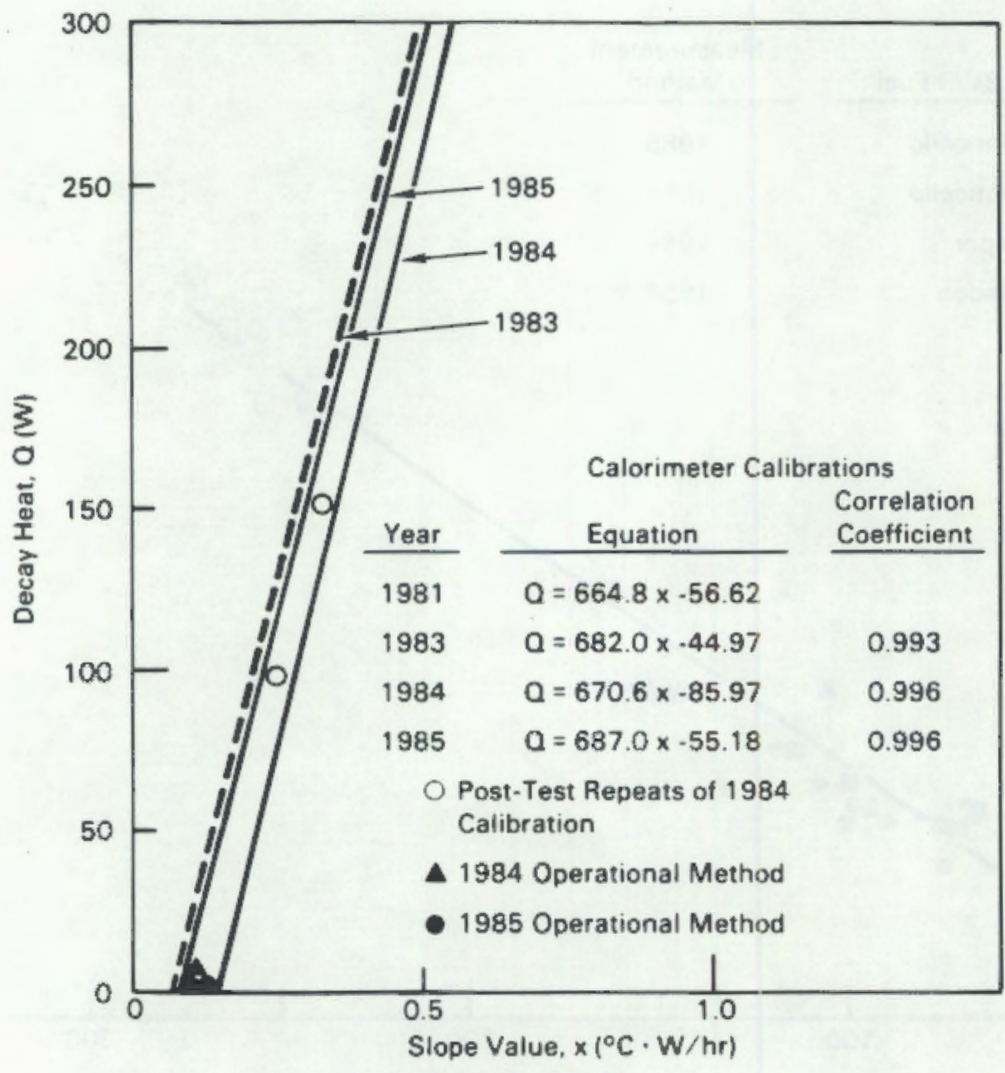

FIGURE 5.7. All Calorimeter Calibration Curves 
-44 to -85 . The $\pm 2 \%$ variation in slope can account for no more than $\pm 5 \mathrm{~W}$ difference over the range of the Monticello data and would not give a constant difference between the measurements and the predictions. However, the intercept value can account for over $40 \mathrm{~W}$ difference. It can easily account for the constant difference between the measurements and the predictions.

Repeat measurements on Dresden assembly DN212 can also be used to assess the calibration of the calorimeter. The assembly was discharged from the Dresden reactor in February 1972 and had an ORIGEN2-predicted output of $30 \mathrm{~W}$ in October 1983. This assembly was measured four times during the period from October 1983 to October 1985. The results of these measurements are shown in Table 5.2. It is interesting to note that the most recent measurement on DN212 shows the same trend as the Monticello assemblies: the ORIGEN2 prediction is lower than the calorimeter measurements. Previous measurements were less than the predictions.

The 1984 and 1985 calibrations of the calorimeter were the first attempts to quantify the performance of the calorimeter with no power to the electrical heater. In the 1985 calibration, the slope of the heat-up curve at zero power was measured to be 0.1637 and 0.1964 . In the 1984 calibration, the slope at zero power was measured to be 0.1564 . These three points are plotted on Figure 5.3 and are much closer together than their respective calibration curves. The differences in the various calibration curves could be associated with

TABLE 5.2. Dresden Assembly DN212 Repeat Measurements

\begin{tabular}{|c|c|c|}
\hline $\begin{array}{l}\text { Measurement } \\
\text { Date } \\
\end{array}$ & Slope & $\begin{array}{c}\text { Measured Decay } \\
\text { Heat, W(a) }\end{array}$ \\
\hline $10 / 83$ & 0.1952 & 29.5 \\
\hline $10 / 03 / 84$ & 0.2364 & 0.1 \\
\hline $10 / 18 / 84$ & 0.2853 & 22.0 \\
\hline $10 / 85$ & 0.2436 & 39.2 \\
\hline
\end{tabular}

(a) Based on respective 1983, 1984, and 1985 calibration curves. 
power measurements during calibration with the electric heater. Further investigation into this hypothesis was not within the scope of this study. It is apparent from comparison of all ORIGEN2 predictions with BWR calorimetry data that, for assemblies of interest to at-reactor and interim storage facilities (200 $\mathrm{W}$ or greater), ORIGEN2 predictions are accurate to within $\pm 10 \%$, an acceptable range.

Based on these results, additional effort should be extended to isolate the source of the calibration offset error. Without further study, the predictions appear to be as good as, if not better than, the measurements. The results also show that the data repeatability is sensitive to the operational method used and that the accuracy of the data is linked to the calibration process.

\subsubsection{Axial Decay Heat Profiles}

The comparison between the predicted axial decay heat profile and the measured gamma output of the fuel assemblies is shown in Figure 5.8. The precalorimetry prediction was made by using the core-averaged axial burnup distribution. The measurement data was obtained with the ION-1. The core-averaged axial gamma ray source is predicted to be very close to the axial burnup distribution because the total gamma ray source strength is proportional to burnup to within $5 \%$ for burnups above 5.0 GWd/MTU. The ION-1 distribution is based on an average of the normalization of the measured values shown in Table 3.4. The degree to which the predicted axial gamma profile departs from the measurements depends upon local influences from control rods, the axial burnup distributions of adjacent assemblies, and the local steam void history. 


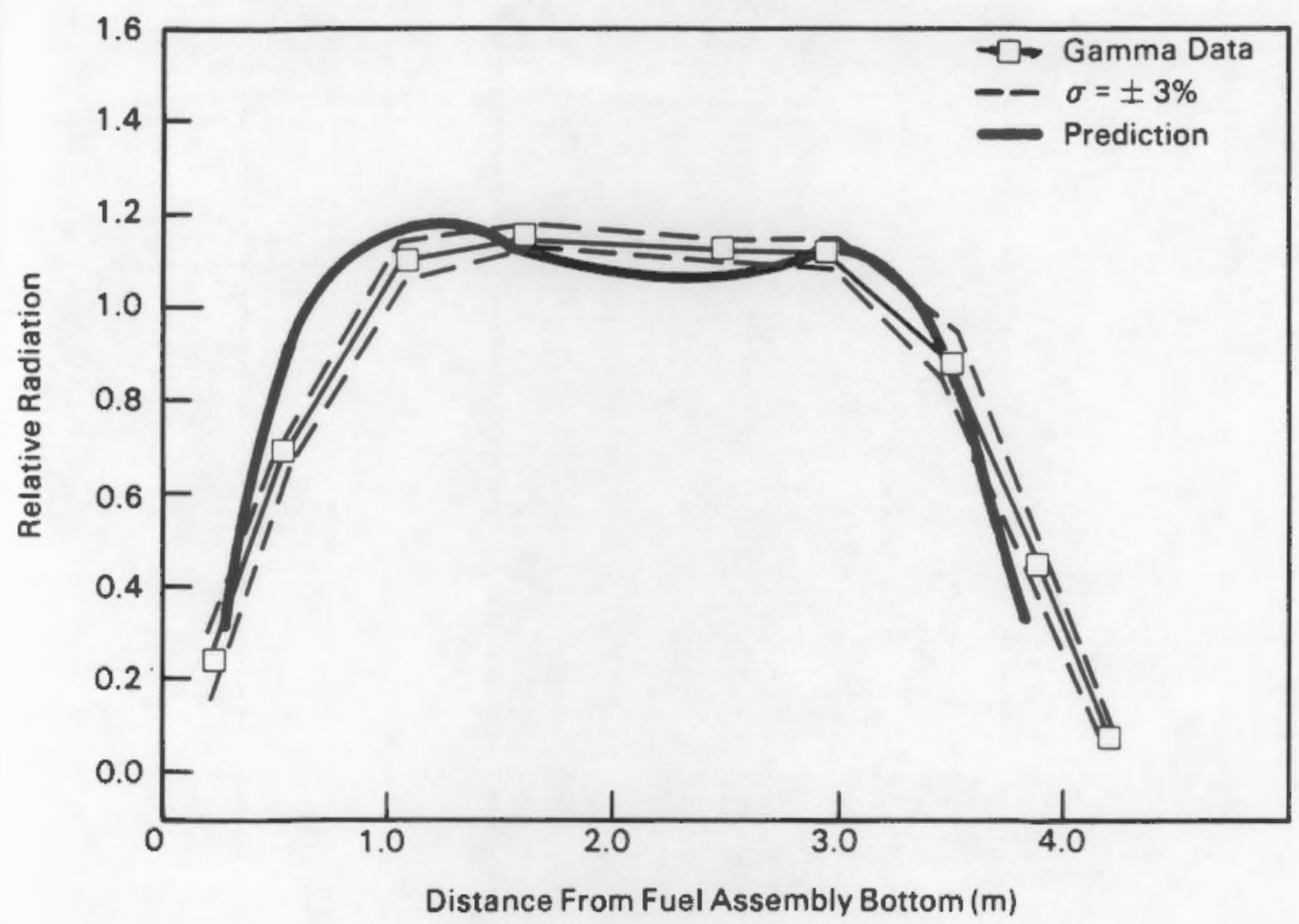

FIGURE 5.8. Monticello Spent Fuel Assembly Measured Average Axial Gamma Profile and Predicted Axial Decay Heat Profile 



\section{REFERENCES}

Barry, R. F. 1963. LEOPARD - A Spectrum Dependent Non-Spatial Depletion Code for the IBM-70 $\overline{94}$. Westinghouse Electric Corporation, Pittsburgh, Pennsylvaria.

Croff, A. G. 1980a. A User's Manual for the ORIGEN2 Computer Code. ORNL/TM-7175, Oak Ridge National Laboratory, Oak Ridge, Tennessee.

Croff, A. G. 1980b. ORIGEN2--A Revised and Updated Version of the Oak Ridge I sotope Generation and Oepletion Code. ORNL-5621, Oak Ridge National Laboratory, Oak Ridge, Tennessee.

Croff, A. G., M. A. Bjerke, J. W. Morrison, and L. M. Petrie. 1978. Revised Uranium-Plutonium Cycle PWR and BWR Models for the ORIGEN Computer Code. ORNL/TM-6051, Oak Ridge Nationa1 Laboratory, Oak Ridge, Tennessee.

Halbig, J. K., and J. C. Caine. 1985. ION-1 Technical Manual. LA-10433-M, Los Alamos National Laboratory, Los Alamos, New Mexico.

Judson, B. F., H. R. Strickler, J. W. Doman, K. J. Eggers, and Y. J. Lee. 1982. In-Plant Test Measurements for Spent Fuel Storage at Morris Operation, Volume 3: Fuel Bundle Heat Generation Rates. NEDG-24922-3, General Electric Company, San Jose, California.

McKinnon, M. A., J. W. Doman, C. M. Heeb, and J. M. Creer, 1985. Decay Heat Measurements and Predictions of BWR Spent Fuel. EPRI NP-4269, Electric Power Research Institute, Palo Alto, California.

MCKinnon, M. A., J. W. Doman, J. E. Tanner, R. J. Guenther, J. M. Creer, and C. E. King. 1986. BWR Spent Fuel Storage Cask Performance Test, Volume I: Cask Handling Experience and Decay Heat, Heat Transfer, and Shielding Data. PNL-5777 Vol. I, Pacific Northwest Laboratory, Richland, Washington.

Schmittroth; F. A. 1984. ORIGEN2 Calculations of PWR Spent Fuel Decay Heat Compared with Calorimeter Data. HEOL-TME 83-32, Westinghouse Hanford Company, Richland, Washington. 


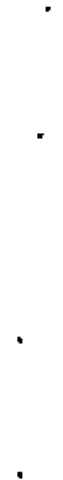


APPENDIX A

CALORIMETER DATA AND CORRECTION FACTORS 


\section{APPENDIX A}

\section{CALORIMETER DATA AND CORRECTION FACTORS}

The first part of this appendix contains the Monticello calorimetry data arranged in chronological order. This is followed by a summary of Cooper and Dresden calorimetry data taken from Mckinnon et al. $(1985,1986)$. The final part of the appendix gives the methodology used to adjust raw calorimeter data for differences in heat capacity between the calibration and measurement mode of operation, and the method used to compensate for gamma energy losses during the measurement mode of operation. 


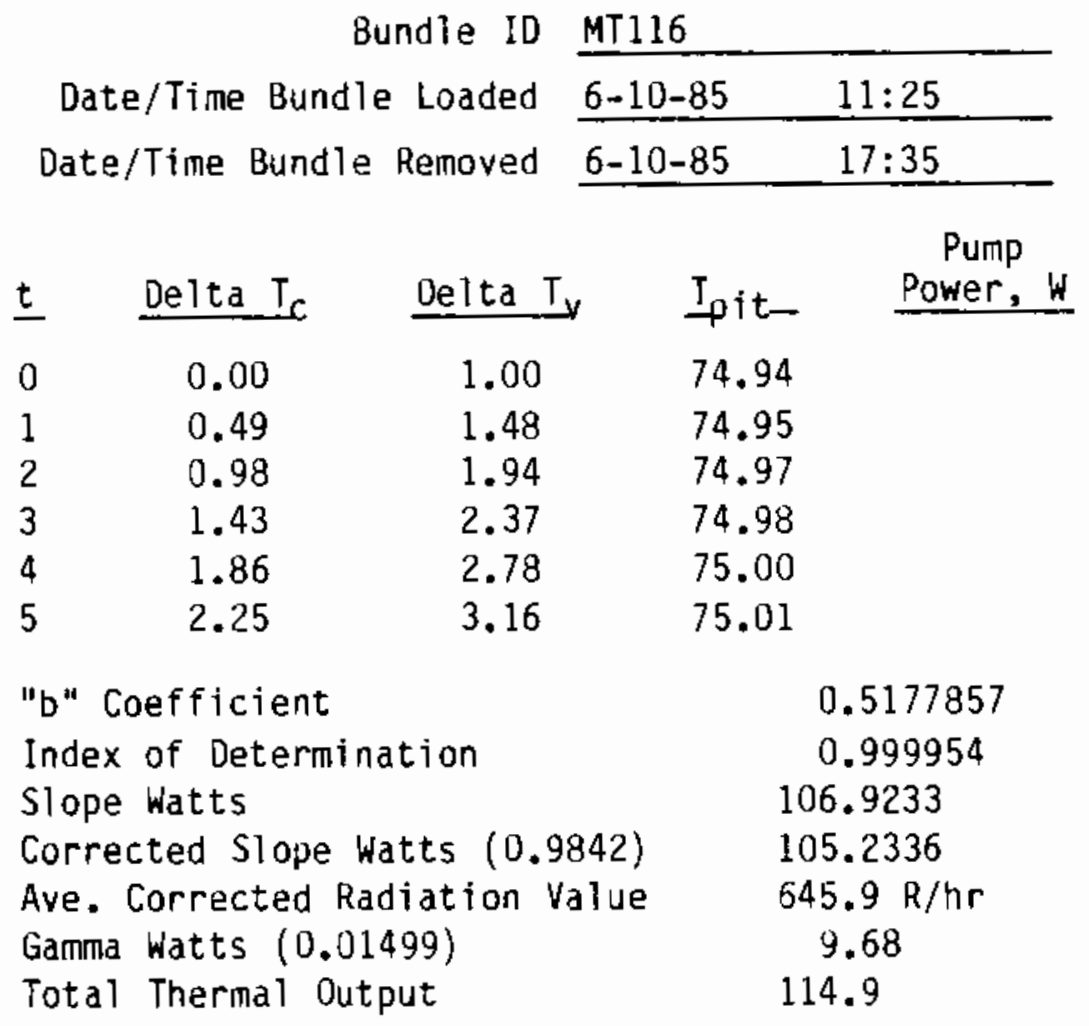

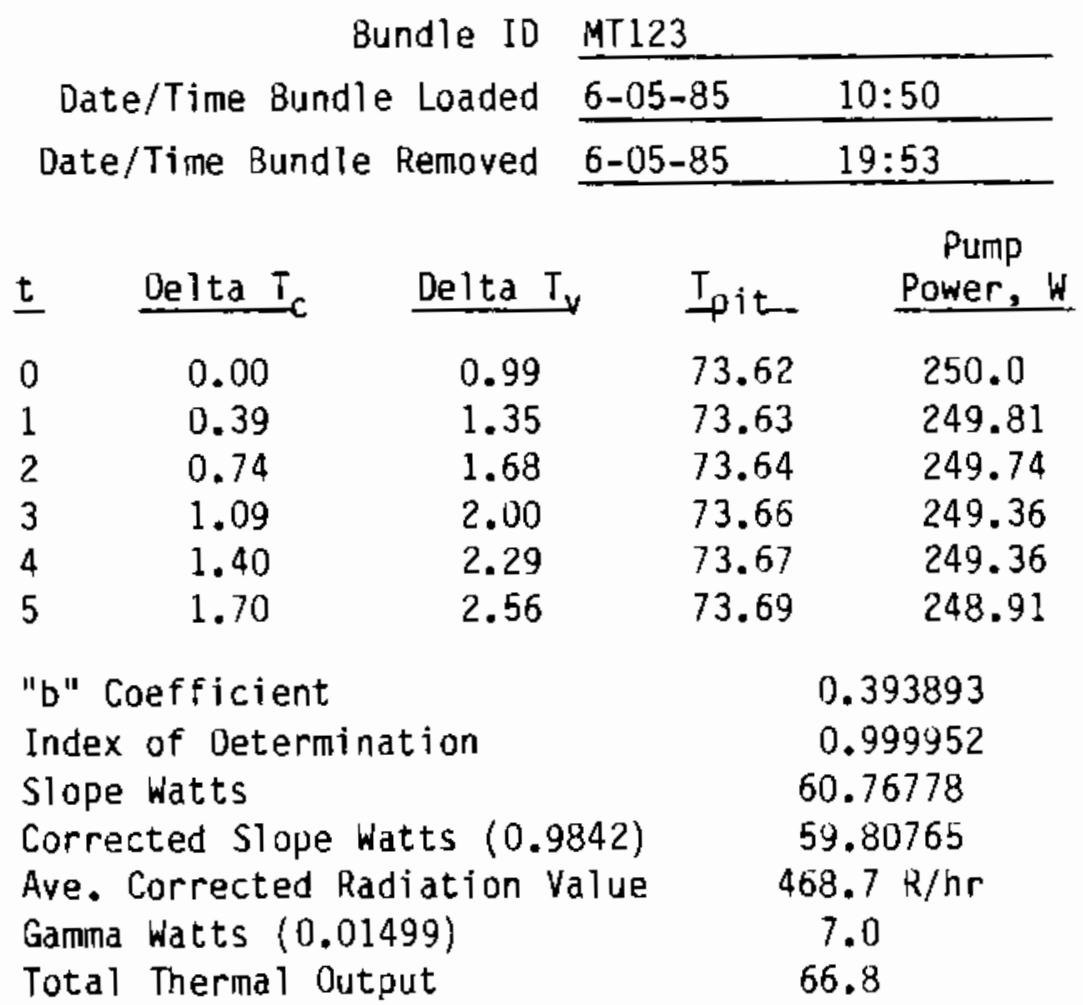




\begin{tabular}{|c|c|c|c|}
\hline \multicolumn{4}{|c|}{ Bundle IO MT123 } \\
\hline \multicolumn{2}{|c|}{ Date/Time Bundle Loaded } & \multicolumn{2}{|c|}{$17: 56$} \\
\hline Date/Time Bundle & Removed $\quad 6-08$ & -85 & 51 \\
\hline Delta $T_{c}$ & Delta $T_{V}$ & Tpit_ & $\begin{array}{c}\text { Pump } \\
\text { Power, W }\end{array}$ \\
\hline 0.00 & 1.00 & 74.49 & 243.02 \\
\hline 0.49 & 1.47 & 74.49 & \\
\hline 0.90 & 1.86 & 74.49 & \\
\hline 1.28 & 2.23 & 74.49 & \\
\hline 1.64 & 2.59 & 74.50 & \\
\hline 2.00 & 2.92 & 74.52 & \\
\hline \multicolumn{3}{|l|}{ "b" Coefficient } & 10358 \\
\hline \multicolumn{2}{|c|}{$\begin{array}{l}\text { Corrected Slope Watts }(0.9842) \\
\text { Ave. Corrected Radiation Value } \\
\text { Gamma Watts }(0.01499) \\
\text { Total Thermal Output }\end{array}$} & \multicolumn{2}{|c|}{$\begin{array}{c}89.5069 \\
88.09269 \\
481.9 \mathrm{R} / \mathrm{hr} \\
7.22 \\
95.3\end{array}$} \\
\hline
\end{tabular}

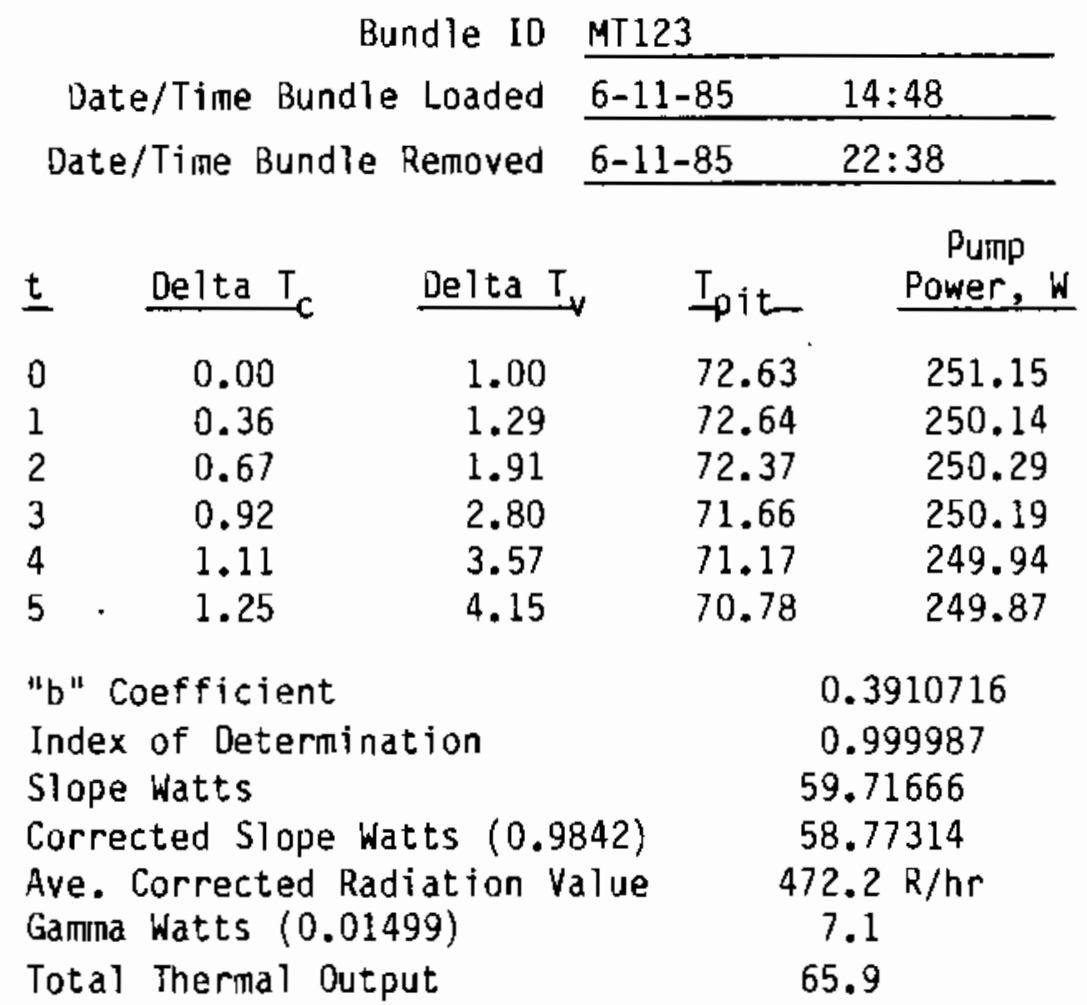




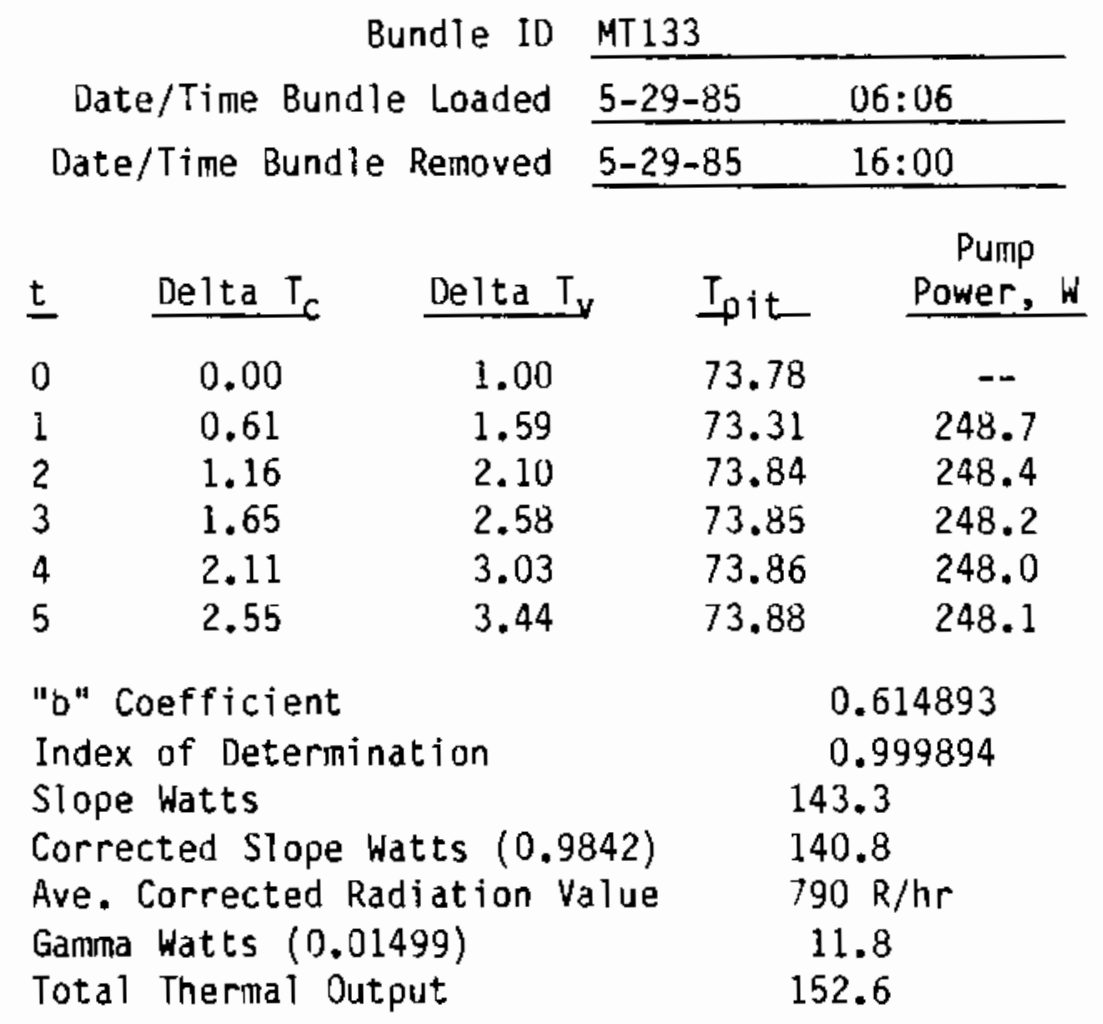

\begin{tabular}{|c|c|c|c|c|c|}
\hline \multicolumn{6}{|c|}{ Bundle ID MT133 } \\
\hline \multicolumn{3}{|c|}{ Date/Time Bundle Loaded } & \multicolumn{2}{|c|}{$6-06-85$} & $12: 46$ \\
\hline \multicolumn{2}{|c|}{ Date/Time Bundle } & Removed & \multicolumn{2}{|c|}{$6-06-85$} & $23: 59$ \\
\hline$\underline{t}$ & $\underline{\text { Delta }}_{c}$ & Delta Tr & & $\stackrel{T}{T_{p i t}}$ & $\begin{array}{c}\text { Pump } \\
\text { Power, }\end{array}$ \\
\hline 0 & 0.00 & 1.00 & & 73.92 & 243.93 \\
\hline 1 & 0.55 & 1.50 & & 73.93 & 245.72 \\
\hline 2 & 1.03 & 1.98 & & 73.95 & 245.64 \\
\hline 3 & 1.51 & 2.42 & & 73.97 & 245.53 \\
\hline 4 & 1.95 & 2.85 & & 73.98 & 245.56 \\
\hline 5 & 2.35 & 3.23 & & 73.99 & 245.36 \\
\hline \multicolumn{5}{|c|}{ "b" Coefficient } & 0.5506787 \\
\hline \multicolumn{5}{|c|}{ Index of Determination } & 0.99993 \\
\hline \multicolumn{4}{|c|}{ Slope Watts } & \multicolumn{2}{|c|}{119.1774} \\
\hline \multirow{2}{*}{\multicolumn{4}{|c|}{$\begin{array}{l}\text { Corrected Slope Watts }(0.9842) \\
\text { Ave. Corrected Radiation Value } \\
\text { Gamma Watts }(0.01499)\end{array}$}} & \multicolumn{2}{|c|}{117.2944} \\
\hline & & & & \multicolumn{2}{|c|}{$\begin{array}{l}778.9 \mathrm{R} / \mathrm{hr} \\
11.67\end{array}$} \\
\hline \multicolumn{4}{|c|}{ Total Thermal Output } & \multicolumn{2}{|c|}{129.0} \\
\hline
\end{tabular}


Bundle ID MT133

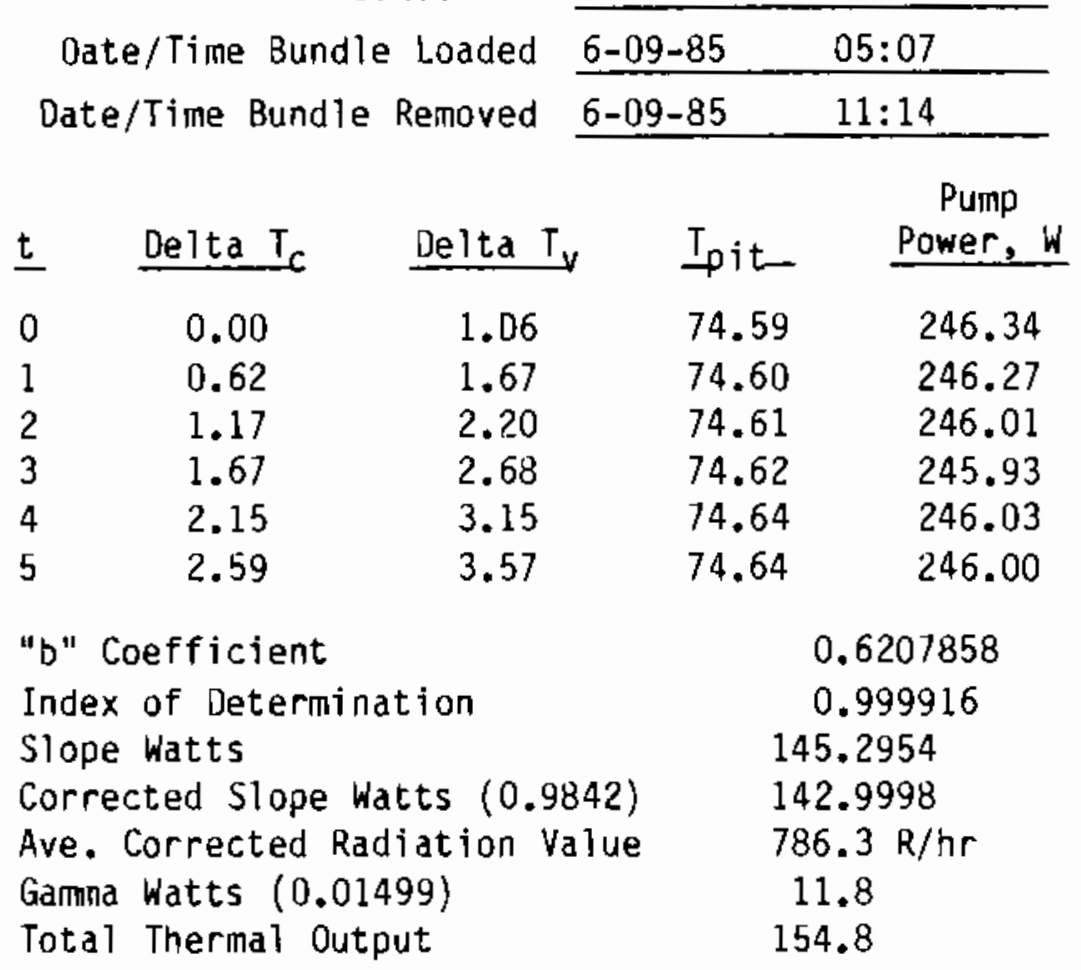

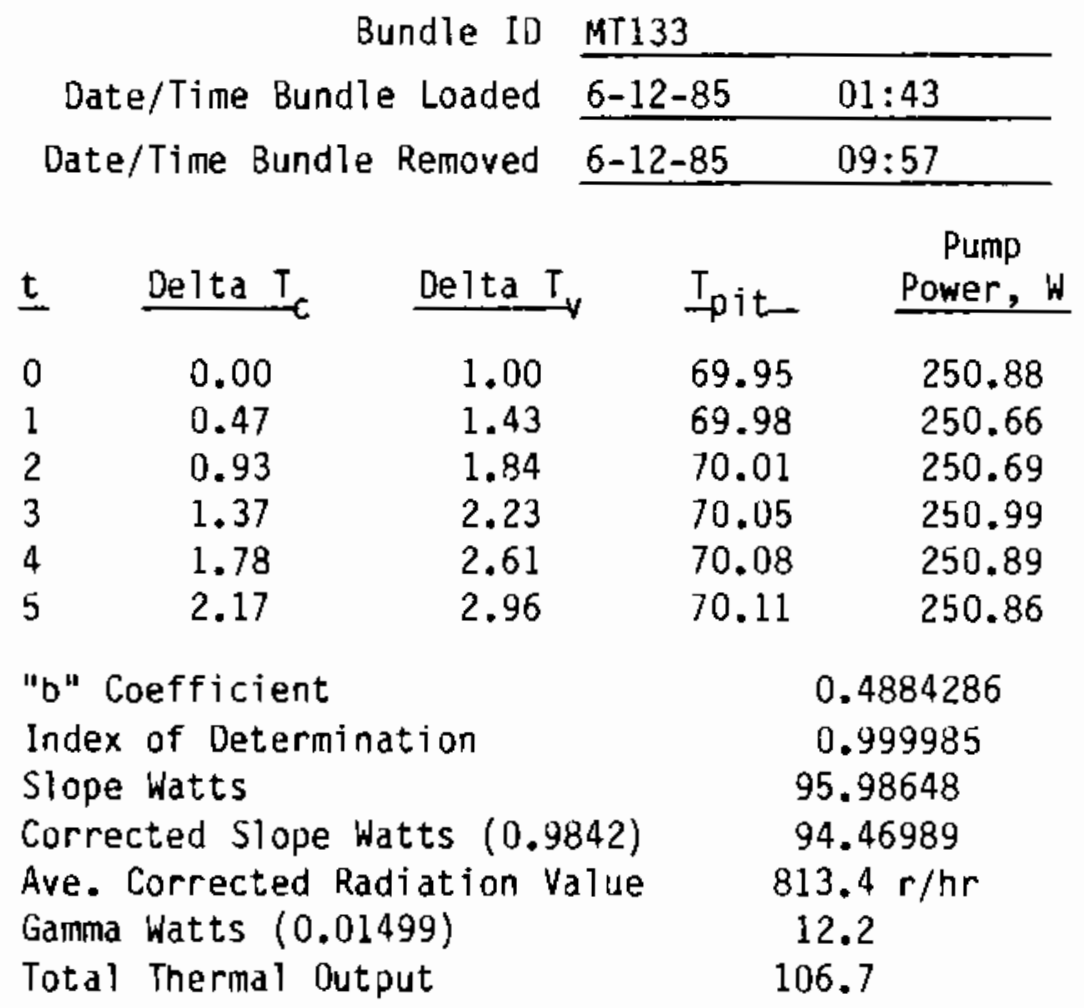




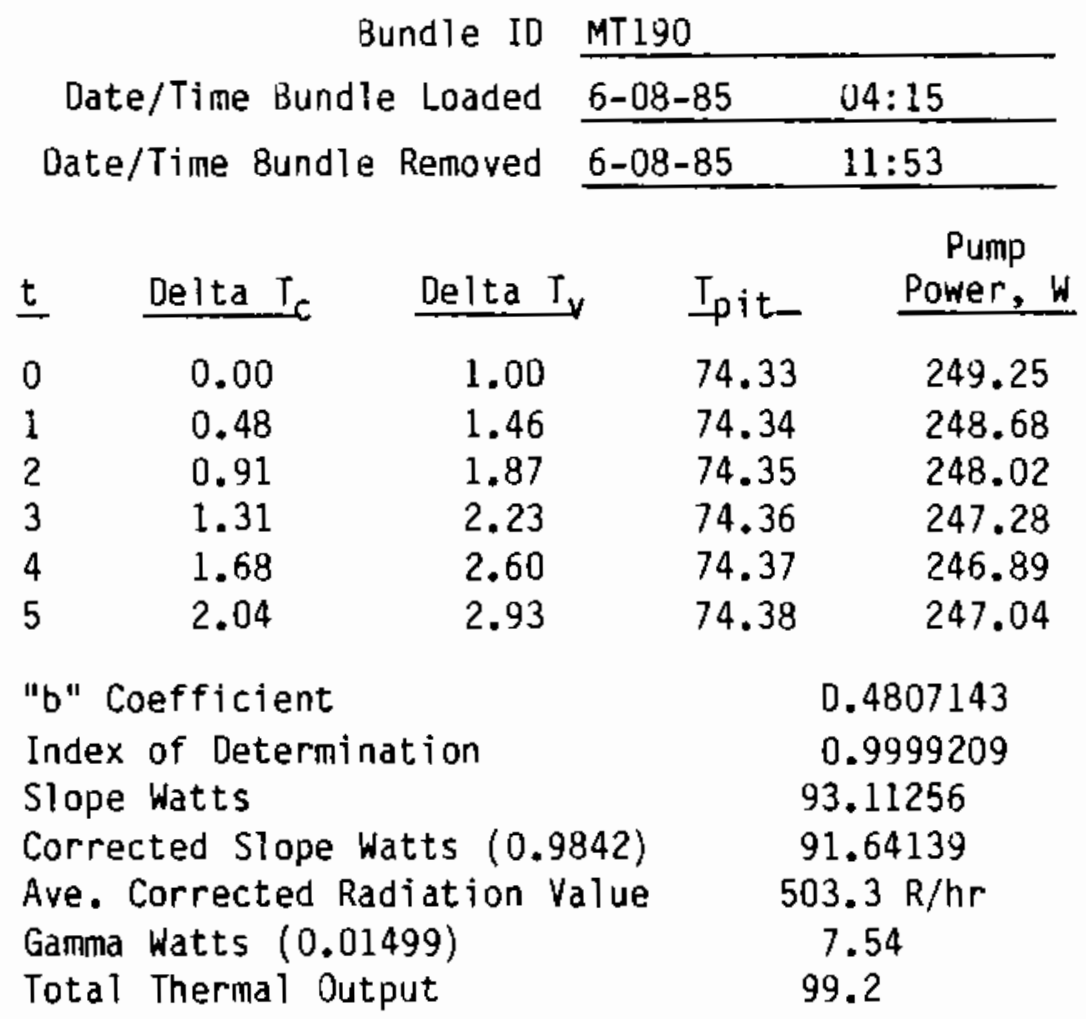

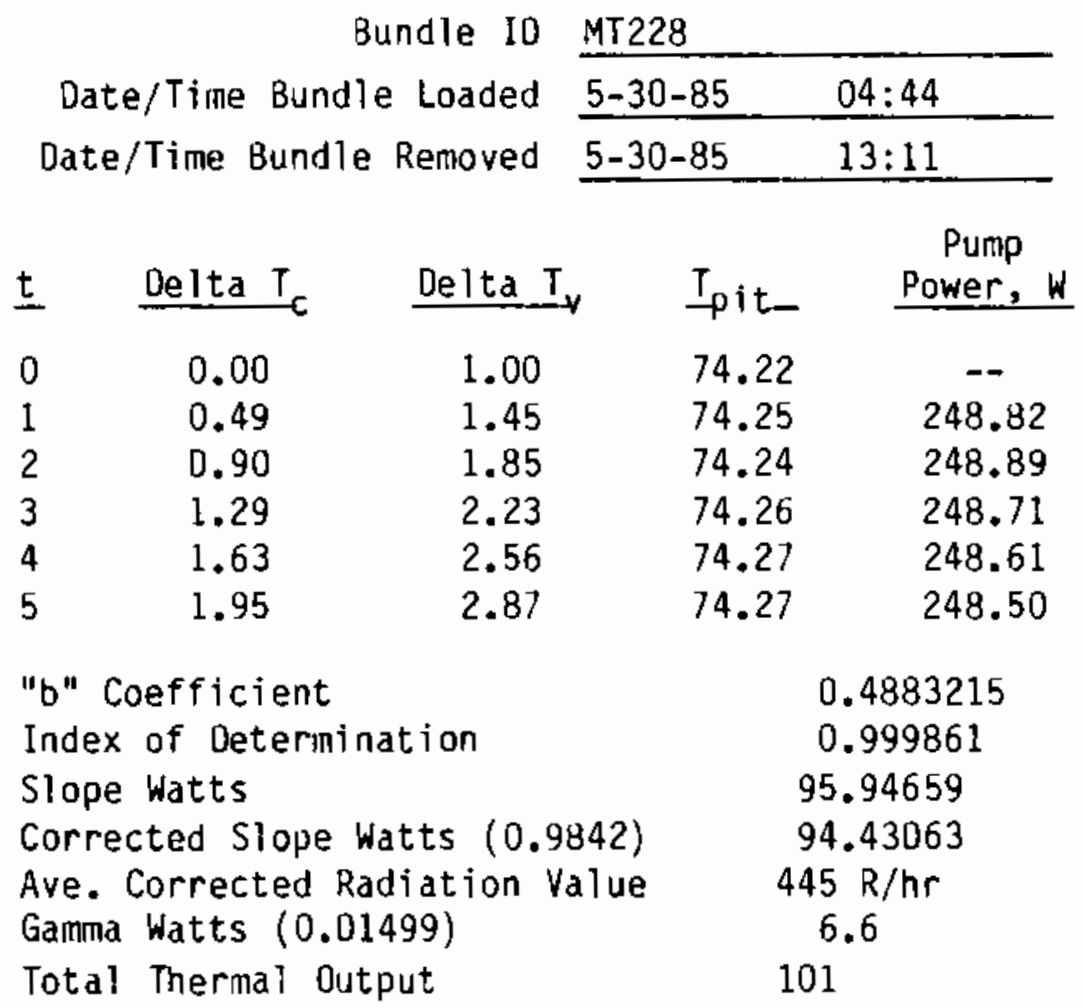




\begin{tabular}{|c|c|c|c|}
\hline \multicolumn{4}{|c|}{ Bundle ID MT228 } \\
\hline \multicolumn{2}{|c|}{ Date/Time Bundle Loaded } & $6-07-85$ & $14: 56$ \\
\hline Date/Time Bundle & Removed & $6-07-85$ & $: 39$ \\
\hline Delta $T_{C}$ & Delta $T_{v}$ & $I_{p i t}$ & $\begin{array}{c}\text { Pump } \\
\text { Power, } W\end{array}$ \\
\hline 0.00 & 1.00 & 74.24 & 247.39 \\
\hline D. 39 & 1.38 & 74.24 & 245.60 \\
\hline 0.77 & 1.73 & 74.25 & 245.60 \\
\hline 1.12 & 2.06 & 74.27 & 245.50 \\
\hline 1.45 & 2.37 & 74.26 & 245.39 \\
\hline 1.75 & 2.66 & 74.27 & 245.34 \\
\hline \multicolumn{3}{|l|}{ "b" Coefficient } & 0.408893 \\
\hline \multicolumn{2}{|c|}{$\begin{array}{l}\text { Index of Determination } \\
\text { Slope Watts } \\
\text { Corrected Slope Watts (0.9842) } \\
\text { Ave. Corrected Radiation Value } \\
\text { Gamma Watts ( } 0.01499) \\
\text { Total Therma1 Output }\end{array}$} & \multicolumn{2}{|c|}{$\begin{array}{l}0.999981 \\
66.35593 \\
65.3075 \\
394.6 \mathrm{R} / \mathrm{hr} \\
5.9 \\
71.2\end{array}$} \\
\hline
\end{tabular}

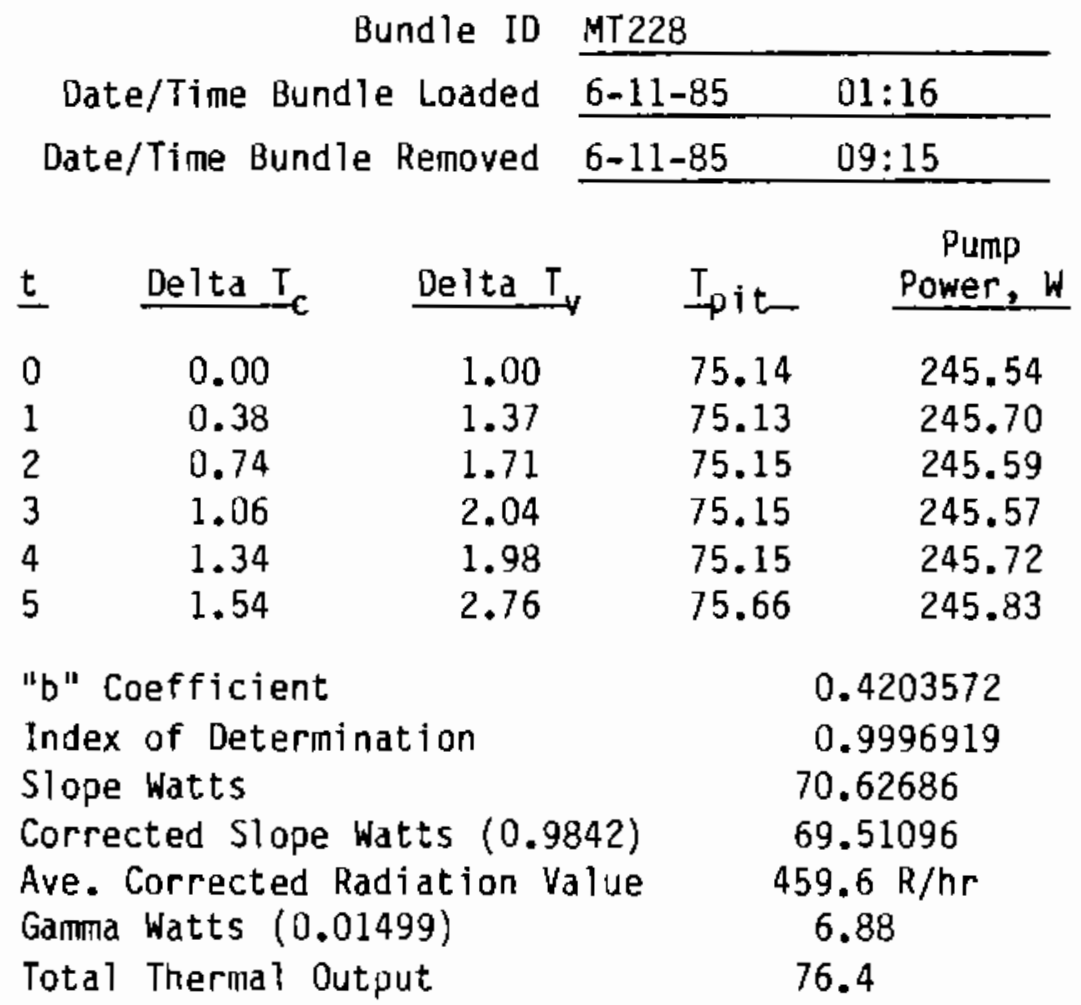

A. 7 


\begin{tabular}{|c|c|c|c|c|c|}
\hline \multicolumn{6}{|c|}{ Bundle ID MT264 } \\
\hline \multicolumn{3}{|c|}{ Date/Time Bundle Loaded } & \multicolumn{2}{|c|}{$6-05-85$} & $23: 25$ \\
\hline \multicolumn{2}{|c|}{ Date/Time Bundle } & Removed & \multicolumn{2}{|c|}{$6-05-85$} & $09: 05$ \\
\hline t & Delta $T_{\text {s }}$ & Delta $T_{v}$ & & Ipit_ & $\begin{array}{c}\text { Pump } \\
\text { Power, } W\end{array}$ \\
\hline 0 & 0.00 & 1.00 & & 73.75 & 246.74 \\
\hline 1 & 0.34 & 1.31 & & 73.76 & 246.61 \\
\hline 2 & 0.65 & 1.62 & & 73.77 & 246.73 \\
\hline 3 & 0.95 & 1.91 & & 73.78 & 246.71 \\
\hline 4 & 1.23 & 2.18 & & 73.79 & 246.81 \\
\hline 5 & 1.50 & 2.42 & & 73.80 & 247.09 \\
\hline \multicolumn{5}{|c|}{ "b" Coefficient } & 0.3411072 \\
\hline \multirow{2}{*}{\multicolumn{5}{|c|}{$\begin{array}{l}\text { Index of Determination } \\
\text { Slope Watts }\end{array}$}} & 0.999974 \\
\hline & & & & & 41.10271 \\
\hline \multicolumn{5}{|c|}{ Corrected Slope Watts $(0.9842)$} & 40.45329 \\
\hline \multirow{2}{*}{\multicolumn{4}{|c|}{$\begin{array}{l}\text { Ave. Corrected Radiation Value } \\
\text { Gamma Watts }(0.01499)\end{array}$}} & \multicolumn{2}{|c|}{$371.6 \mathrm{R} / \mathrm{hr}$} \\
\hline & & & & \multirow{2}{*}{\multicolumn{2}{|c|}{46}} \\
\hline \multicolumn{4}{|c|}{ Total Thermal Output } & & \\
\hline
\end{tabular}

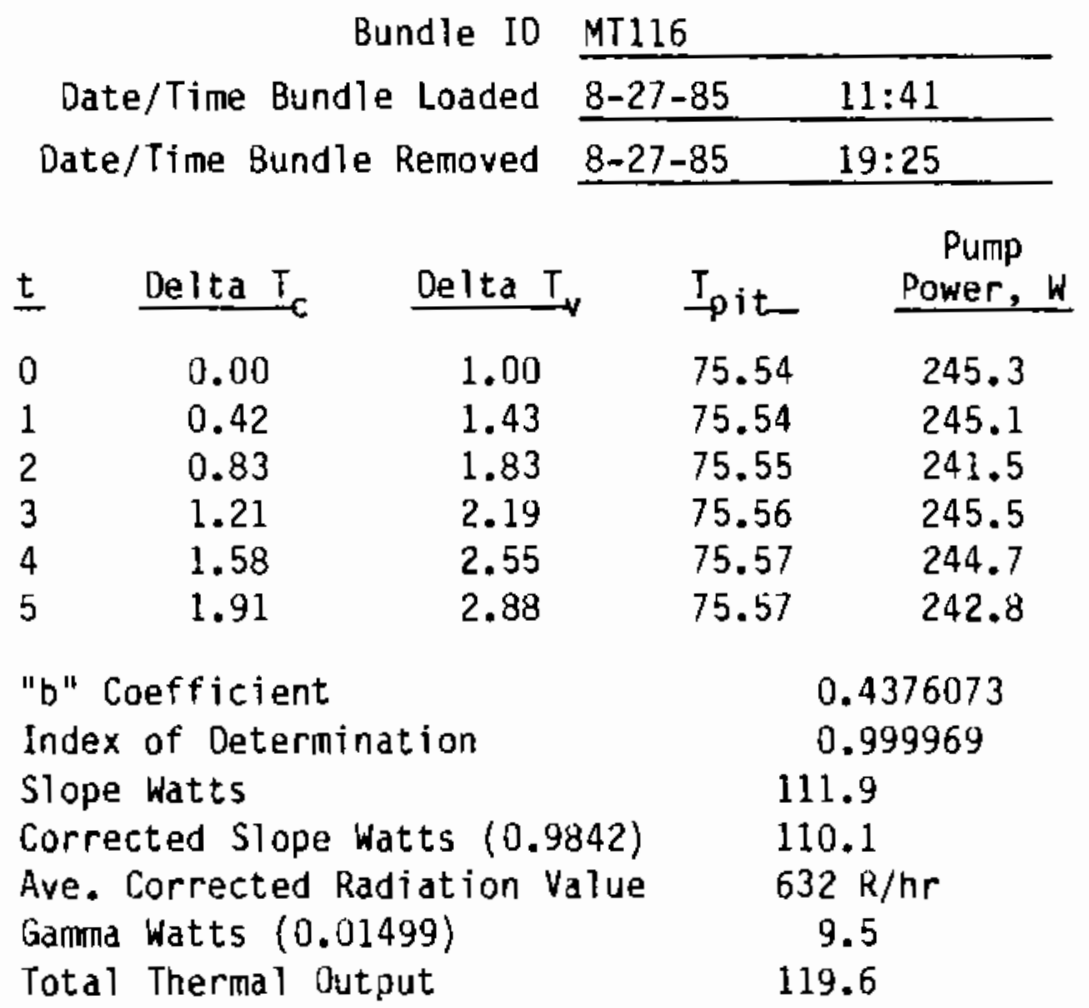




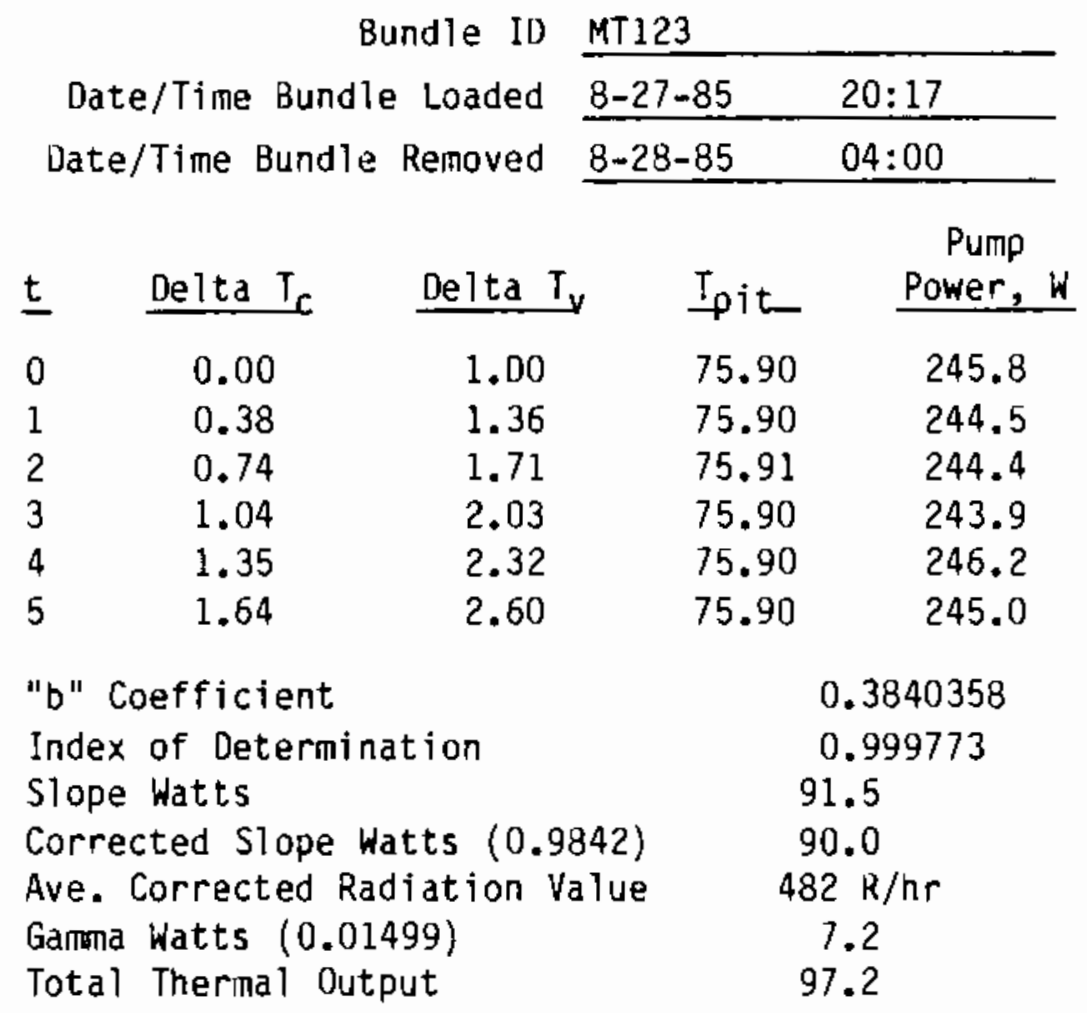

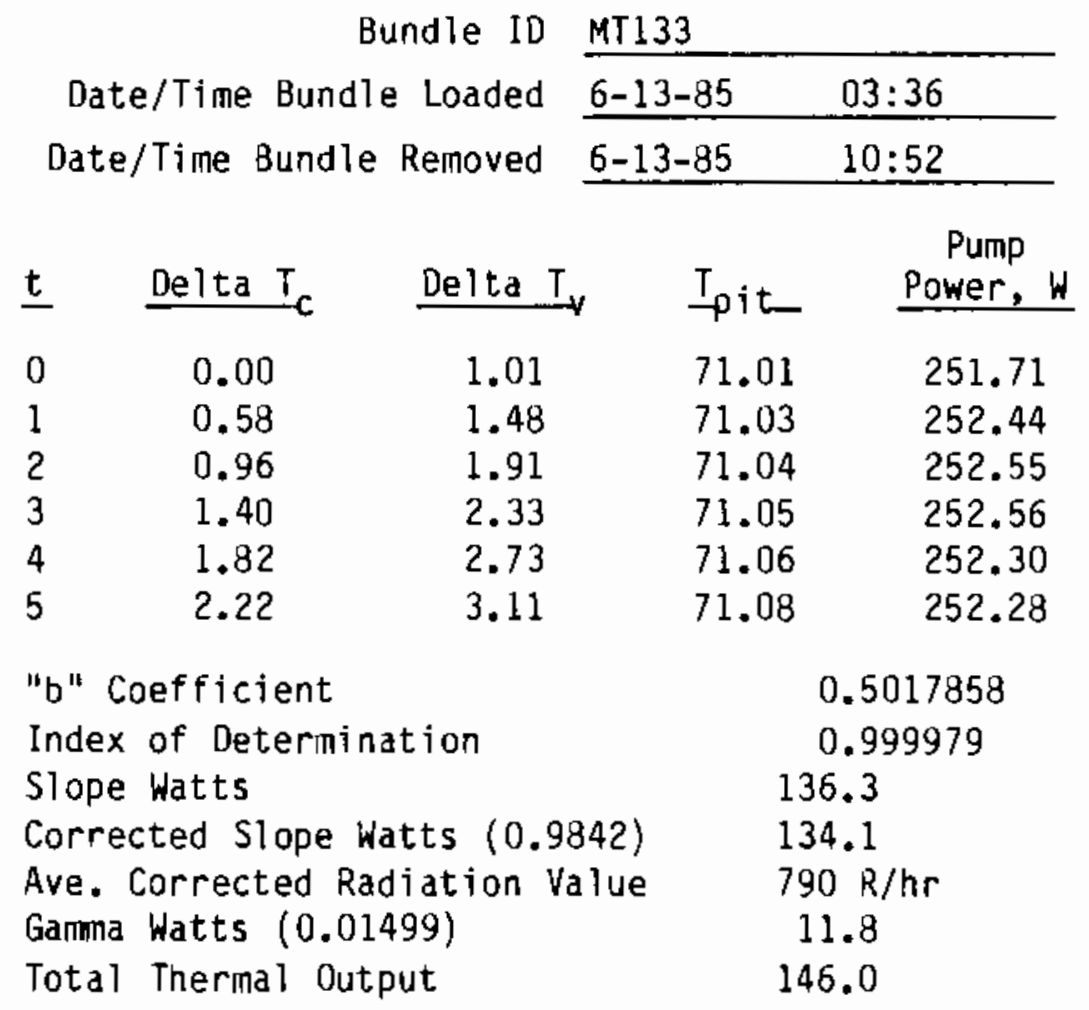




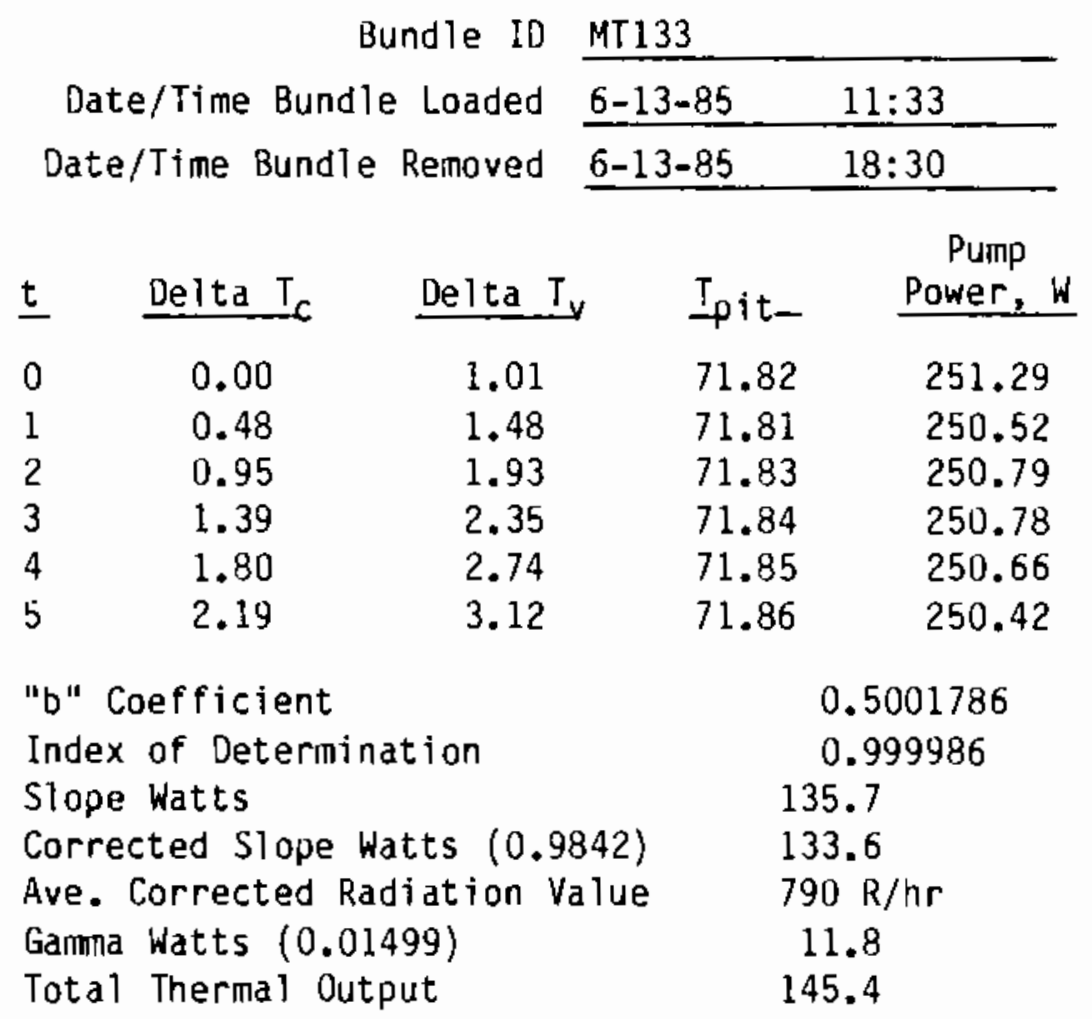

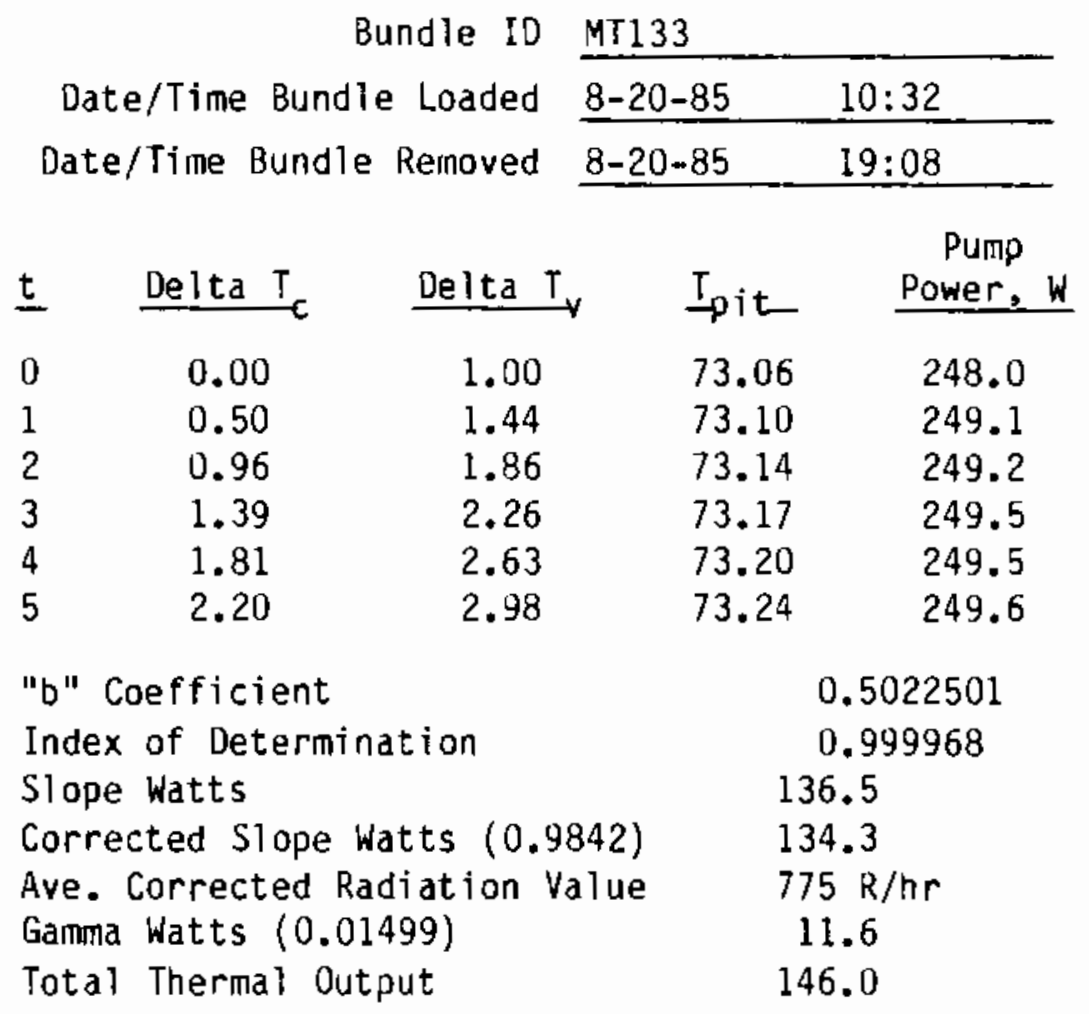


Bundle ID MT133

Date/Time Bundle Loaded 8-21-85 08:32

Date/Time Bundle Removed 8-21-85 16:18

\begin{tabular}{|c|c|c|c|c|}
\hline$\underline{t}$ & Delta $T_{c}$ & Delta $T_{V}$ & Ipit & $\begin{array}{c}\text { Pump } \\
\text { Power, w }\end{array}$ \\
\hline 0 & 0.00 & 1.02 & 74.29 & 248.3 \\
\hline 1 & 0.49 & 1.49 & 74.31 & 248.8 \\
\hline 2 & 0.95 & 1.92 & 74.32 & 249.2 \\
\hline 3 & 1.40 & 2.34 & 74.34 & 248.8 \\
\hline$A_{1}$ & 1.80 & 2.74 & 74.35 & 248.5 \\
\hline 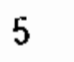 & 2.19 & 3.09 & 74.37 & 248.4 \\
\hline \multicolumn{3}{|c|}{ "b" Coefficient } & \multicolumn{2}{|c|}{0.5040714} \\
\hline \multicolumn{3}{|c|}{ Index of Determination } & \multicolumn{2}{|c|}{0.999972} \\
\hline \multirow{2}{*}{\multicolumn{3}{|c|}{$\begin{array}{l}\text { Slope Watts } \\
\text { Corrected Slope Watts }(0.9842\}\end{array}$}} & \multicolumn{2}{|c|}{137.2} \\
\hline & & & \\
\hline \multirow{2}{*}{\multicolumn{3}{|c|}{$\begin{array}{l}\text { Ave. Corrected Radiation Value } \\
\text { Gamma Watts }(0.01499)\end{array}$}} & \multicolumn{2}{|c|}{$786 \mathrm{R} / \mathrm{hr}$} \\
\hline & & & \multirow{2}{*}{\multicolumn{2}{|c|}{$\begin{array}{r}11.8 \\
146.8\end{array}$}} \\
\hline \multicolumn{3}{|c|}{ Ton } & & \\
\hline
\end{tabular}

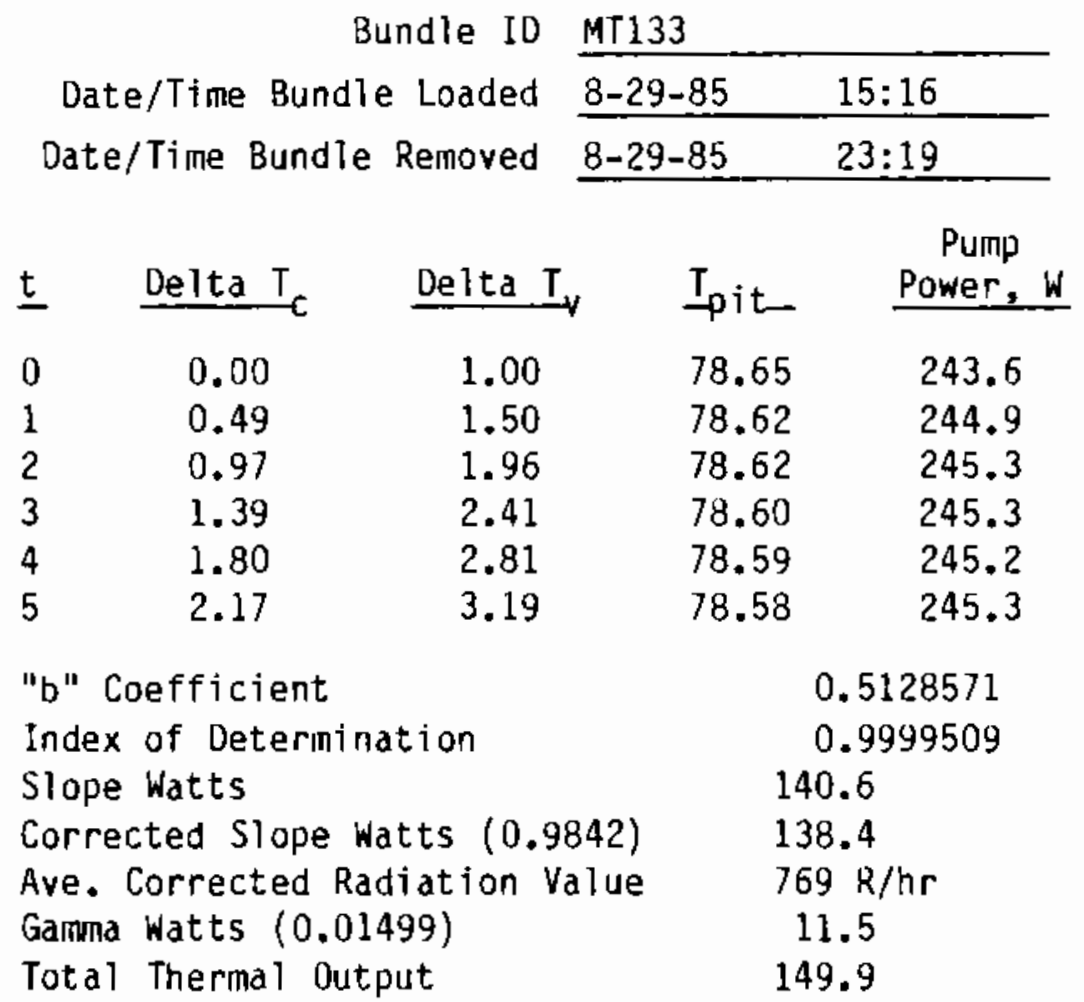




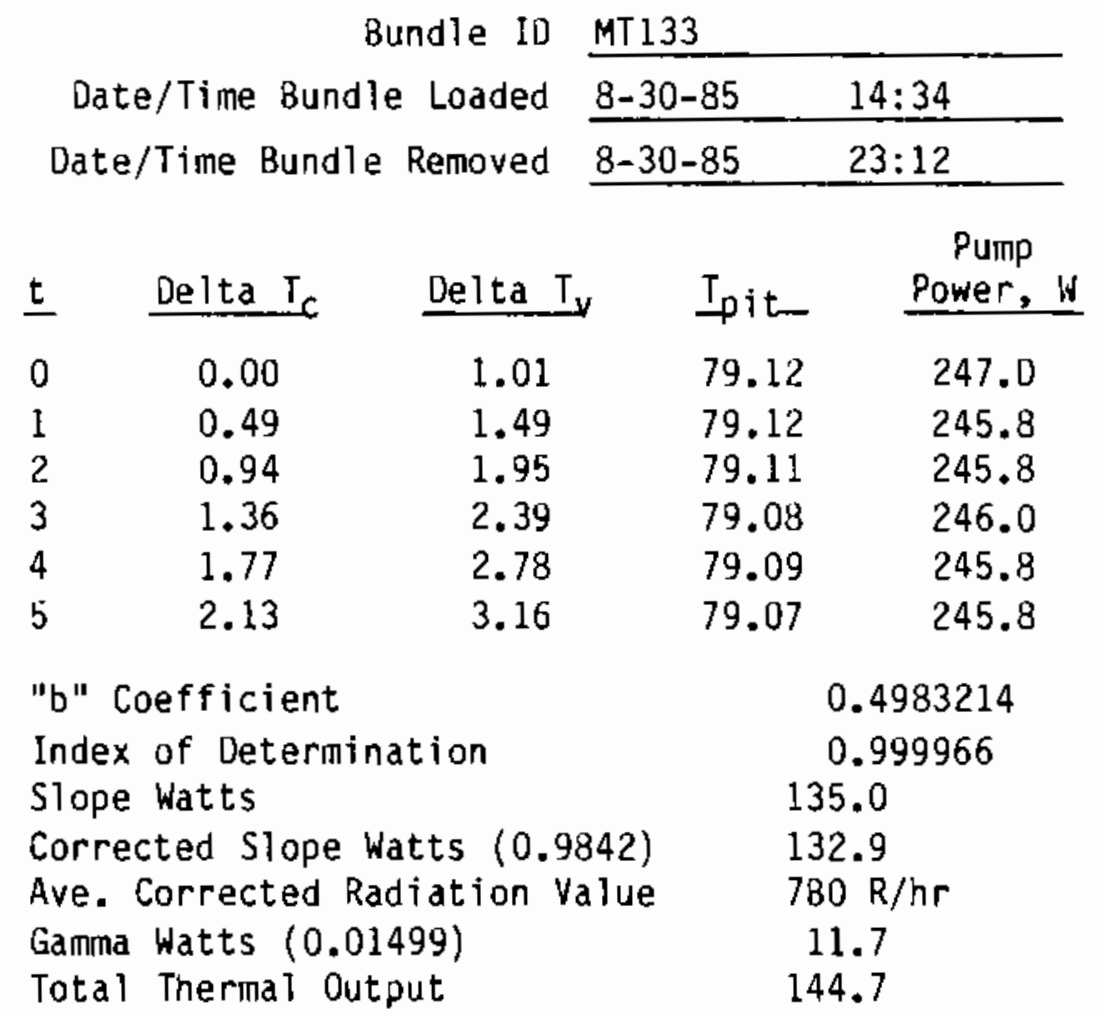

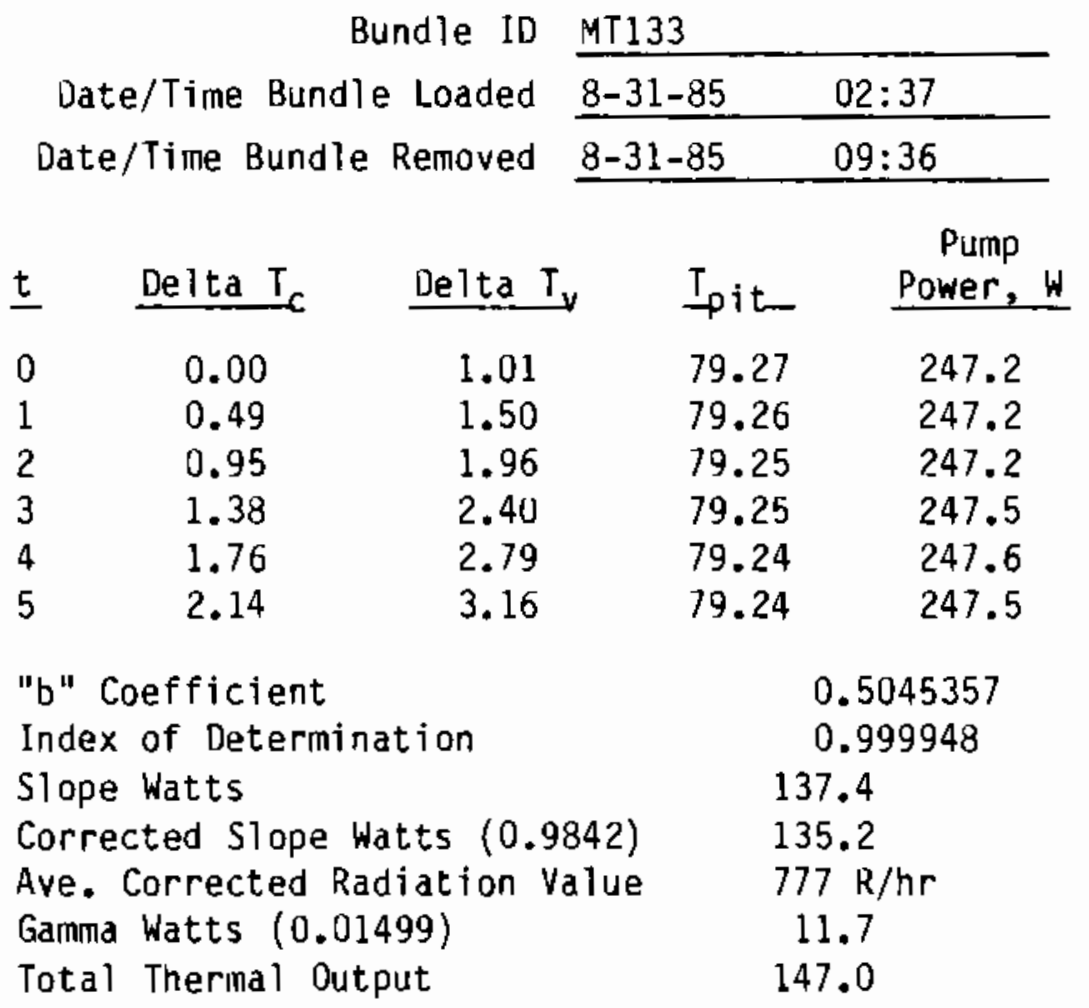




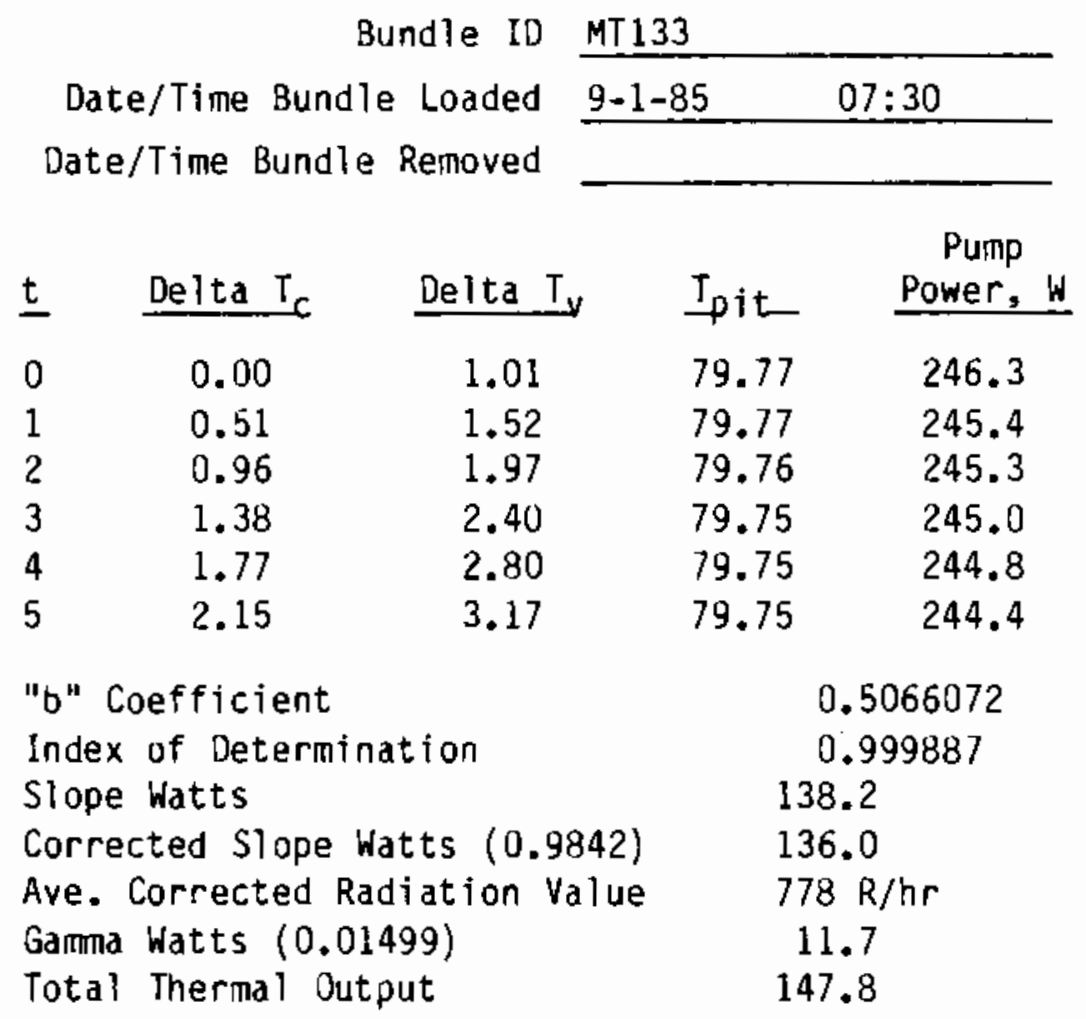

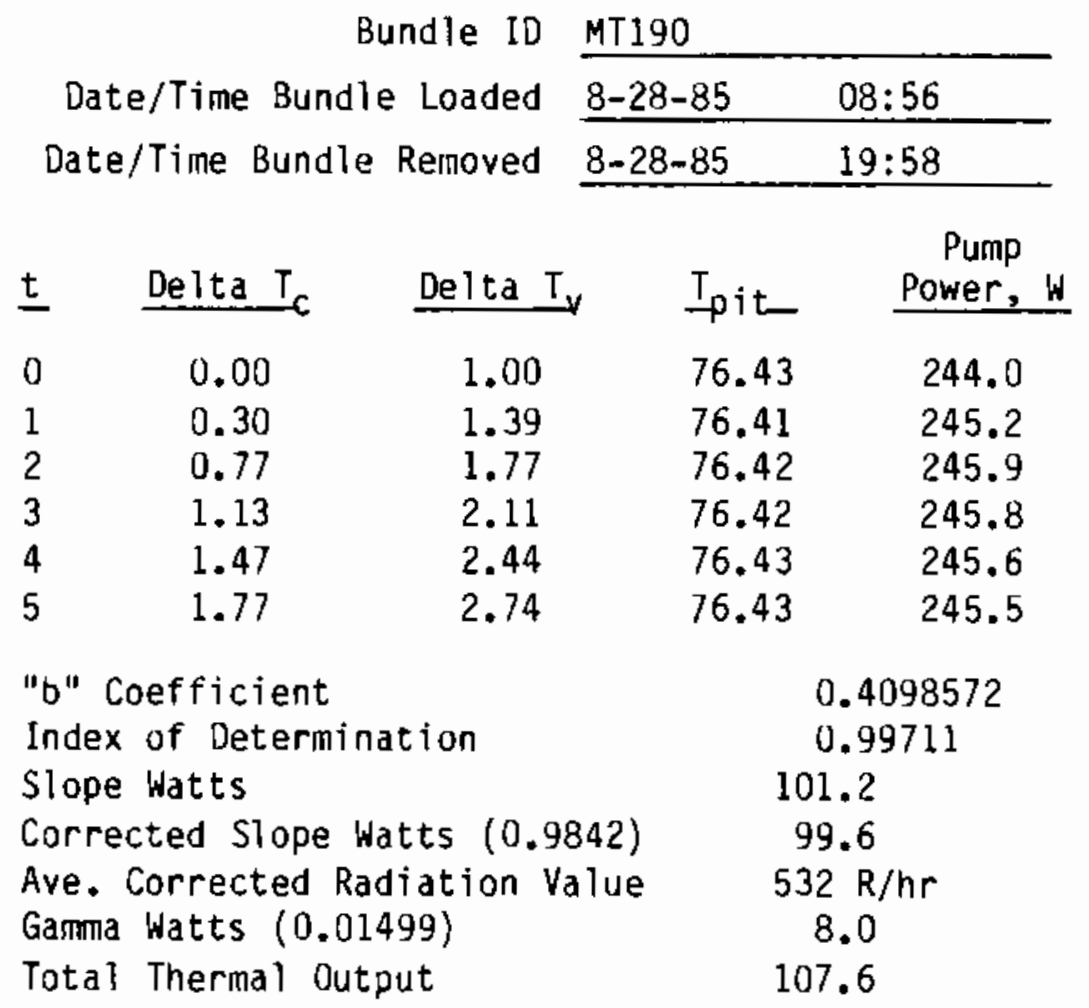




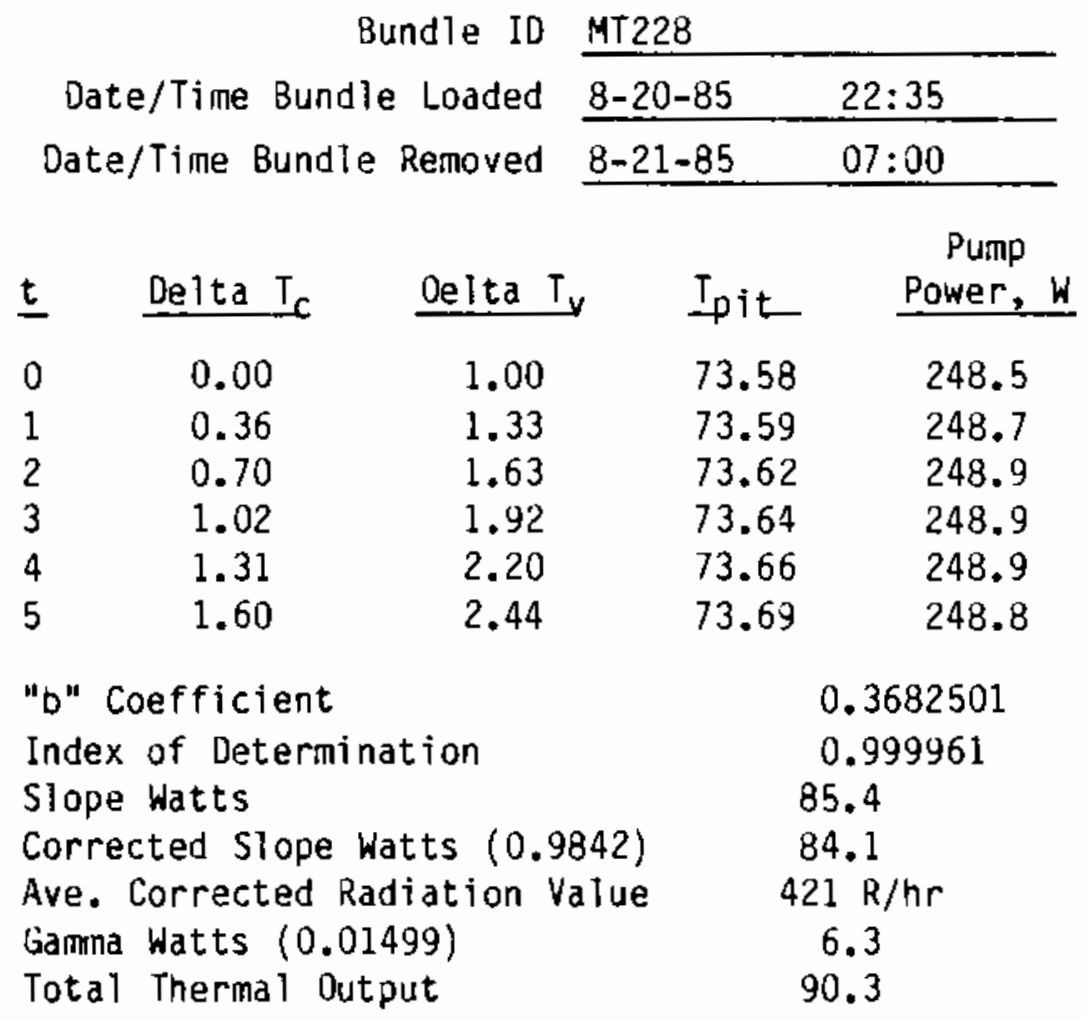

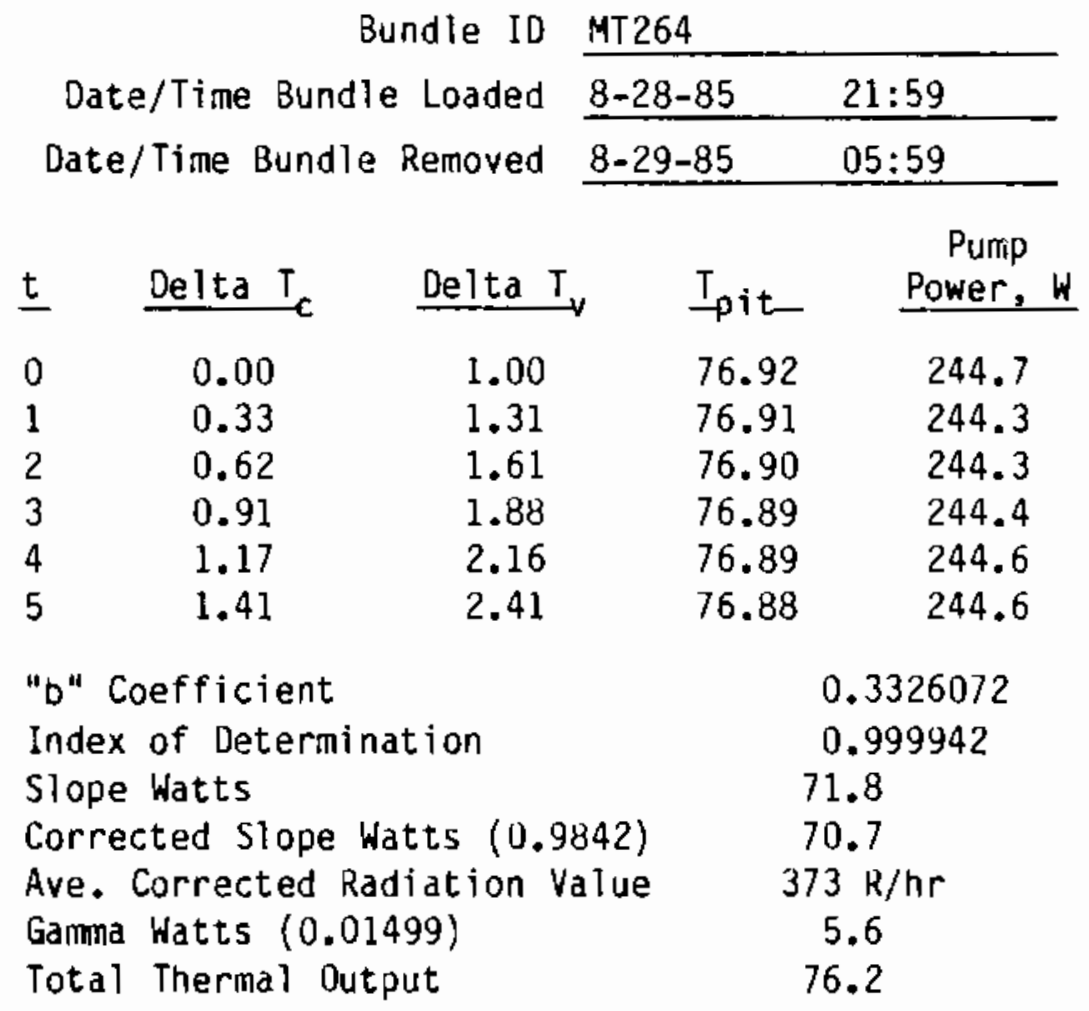


TABLE A.1. Summary of Cooper and Dresden BWR Calorimetry Data

\begin{tabular}{|c|c|c|c|c|c|c|c|c|}
\hline $\begin{array}{l}\text { Assembly } \\
\text { ID } \\
\end{array}$ & $\begin{array}{c}\text { Measureinent } \\
\text { Date } \\
\end{array}$ & $\begin{array}{l}\text { Measured } \\
\text { Decay } \\
\text { Heat, w }\end{array}$ & $\begin{array}{l}\text { Form } 30 \\
\text { Based } \\
\text { Pred., } W\end{array}$ & $\begin{array}{c}\text { Cycle } \\
\text { Sumnary } \\
\text { Based } \\
\text { Pred.2W }\end{array}$ & $\begin{array}{c}\text { Form } 30 \\
\text { Total } \\
\text { Burnup, } \\
\text { GHd/HTU } \\
\end{array}$ & $\begin{array}{c}\text { Cycle } \\
\text { Summary } \\
\text { Total } \\
\text { Burnup, } \\
\text { GWd/MTU } \\
\end{array}$ & $\begin{array}{l}\text { Measured } \\
\text { Minus } \\
\text { Form 30 } \\
\text { Based } \\
\text { Pred.. W }\end{array}$ & $\begin{array}{l}\text { Measured } \\
\text { Minus } \\
\text { Cycle } \\
\text { Summary } \\
\text { Based } \\
\text { Pred.2W }\end{array}$ \\
\hline ON212 & $03-0 c t-84$ & 31.2 & 29.7 & 88.0 & 5.280 & 5.280 & 1.5 & -56.8 \\
\hline ON212 & $18-0 c t-84$ & 19.5 & 29.7 & 29.7 & 5.280 & 5.280 & -10.2 & -10.2 \\
\hline$C Z 102$ & $25-$ Sep -84 & 62.3 & 83.5 & 76.8 & 11.667 & 10.733 & -21.2 & -14.5 \\
\hline$C Z 102$ & 14-Dec-84 & 70.4 & 82.2 & 75.6 & 11.667 & 10.733 & -11.8 & -5.2 \\
\hline CZ147 & $04-$ Nov -84 & 276.7 & 296.4 & 276.9 & 26.709 & 24.952 & -19.7 & -0.2 \\
\hline 62143 & $23-0 c t-84$ & 273.5 & 293.6 & 277.5 & 26.310 & 24.868 & -20.1 & -4.0 \\
\hline $\mathrm{C} 2182$ & 27-Sep-84 & 342.6 & 364.9 & 354.9 & 26.824 & 26.091 & -22.3 & -12.3 \\
\hline CZ195 & $30-0 \mathrm{ct}-84$ & 255.5 & 289.6 & 262.3 & 26.392 & 23.906 & -34.1 & -6.8 \\
\hline CZ205 & 24-Sер-84 & 324.0 & 329.5 & 335.3 & 25.344 & 25.793 & -5.5 & -11.3 \\
\hline$C 2205$ & $04-0 c t-84$ & 361.5 & 326.6 & 332.4 & 25.344 & 25.793 & 34.9 & 29.1 \\
\hline$C 2205$ & $08-0 c t-84$ & 343.5 & 325.1 & 330.9 & 25.344 & 25.793 & 18.4 & 12.6 \\
\hline $\mathrm{C} 2205$ & $09-0 \mathrm{ct}-84$ & 352.9 & 324.8 & 330.6 & 25.344 & 25.793 & 29.1 & 22.9 \\
\hline$c 2205$ & $23-0 c t-84$ & 331.8 & 320.6 & 326.3 & 25.344 & 25.793 & 11.2 & 5.5 \\
\hline $\mathrm{C} 2205$ & $24-0 c t-84$ & 338.7 & 320.3 & 326.0 & 25.344 & 25.793 & 18.4 & 12.7 \\
\hline CZ205 & $29-0 \mathrm{ct}-84$ & 327.5 & 319.1 & 324.8 & 25.344 & 25.793 & 8.4 & 2.7 \\
\hline$C Z 205$ & $02-N o v-84$ & 313.1 & 318.5 & 324.1 & 25.344 & 25.793 & -5.4 & -11.0 \\
\hline$C 2205$ & $05-$ Nov-84 & 311.4 & 317.0 & 322.6 & 25.344 & 25.793 & -5.6 & -11.2 \\
\hline CZ205 & 06-Dec-84 & 314.0 & 308.2 & 313.7 & 25.344 & 25.793 & 5.8 & 0.3 \\
\hline$C 2205$ & $12-$ Dec- -84 & 331.2 & 306.5 & 311.9 & 25.344 & 25.793 & 24.7 & 19.3 \\
\hline$C Z 205$ & $22-1) \mathrm{ec}-84$ & 317.1 & 303.6 & 309.0 & 25.344 & 25.793 & 13.5 & 8.1 \\
\hline$C Z 205$ & 14-May-85 & 289.7 & 276.0 & 280.9 & 25.344 & 25.792 & 13.7 & 8.8 \\
\hline CZ205 & 28-May-85 & 308.0 & 273.6 & 278.4 & 25.344 & 25.792 & 34.4 & 29.6 \\
\hline C2209 & $28-0 c t-84$ & 279.5 & 295.1 & 291.3 & 25.383 & 25.056 & -15.6 & -11.8 \\
\hline$C 2211$ & $20-0 c t-84$ & 296.0 & 302.7 & 283.2 & 26.679 & 24.958 & -6.7 & 12.8 \\
\hline C2211 & 20-May-85 & 240.3 & 266.6 & 249.4 & 26.679 & 24.958 & -26.3 & -9.1 \\
\hline CZ2222 & 04-Nov-84 & 355.7 & 346.2 & 345.8 & 26.692 & 26.665 & 9.5 & 9.9 \\
\hline CZ2225 & $02-0 c t-84$ & 327.3 & 321.4 & 322.8 & 25.796 & 25.905 & 5.9 & 4.5 \\
\hline $\mathrm{CZ} 239$ & $30-0 \mathrm{ct}-84$ & 366.5 & 358.8 & 357.3 & 27.246 & 27.130 & 7.7 & 9.2 \\
\hline$C Z 246$ & $02-$ Nov-84 & 320.9 & 364.4 & 356.4 & 27.363 & 26.750 & -43.5 & -35.5 \\
\hline$C Z 246$ & $05-\mathrm{Nav}-84$ & 341.7 & 363.4 & 355.4 & 27.363 & 26.760 & -21.7 & -13.7 \\
\hline$C Z 259$ & $28-0 c t-84$ & 247.6 & 293.3 & 265.2 & 26.466 & 23.930 & -45.7 & -17.6 \\
\hline$C 2259$ & $20-D e c-84$ & 288.5 & 284.0 & 256.8 & 26.466 & 23.930 & 4.5 & 31.7 \\
\hline C2259 & $14-4 a y-85$ & 254.1 & 260.0 & 235.1 & 26.466 & 23.930 & -5.9 & 19.0 \\
\hline CZ264 & $23-0 \mathrm{ct}-84$ & 263.8 & 292.6 & 262.5 & 26.496 & 23.767 & -28.8 & 1.3 \\
\hline 0.2277 & $28-0 \mathrm{ct}-84$ & 262.7 & 290.9 & 262.5 & 26.478 & 23.891 & -28.2 & 0.2 \\
\hline $\mathrm{C} 2277$ & 26-May-85 & 243.0 & 261.2 & 235.7 & 26.478 & 23.891 & -18.2 & 7.3 \\
\hline$C 2286$ & $06-\mathrm{Dec}-84$ & 278.4 & 326.8 & 313.8 & 27.141 & 26.065 & -48.4 & -35.4 \\
\hline$C 2286$ & 29-May-85 & 284.2 & 290.8 & 279.3 & 27.141 & 26.065 & -5.6 & 4.9 \\
\hline c 2296 & $03-N o v-84$ & 256.7 & 297.0 & 281.1 & 26.388 & 24.973 & -40.3 & -24.4 \\
\hline C7296 & $21-M a y-85$ & 251.9 & 266.0 & 251.7 & 26.388 & 24.973 & -14.1 & 0.2 \\
\hline$C 2302$ & $24-0 c t-84$ & 285.6 & 290.8 & 289.0 & 26.594 & 26.432 & -5.2 & -3.4 \\
\hline CZ308 & $01-$ Nov-84 & 269.7 & 298.7 & 287.2 & 25.815 & 24.817 & -29.0 & -17.5 \\
\hline C2311 & $27-0 c t-84$ & 356.9 & 340.1 & 328.5 & 27.392 & 26.455 & 16.8 & 28.4 \\
\hline$C 2315$ & $08-1) c-84$ & 328.0 & 317.2 & 303.1 & 26.881 & 25.685 & 10.8 & 24.9 \\
\hline
\end{tabular}


TABLE A.1. (contd)

\begin{tabular}{|c|c|c|c|c|c|c|c|c|}
\hline $\begin{array}{l}\text { Assembly } \\
\text { ID } \\
\end{array}$ & $\begin{array}{c}\text { Measurement } \\
\text { Date }\end{array}$ & $\begin{array}{c}\text { Measured } \\
\text { Decay } \\
\text { Heat, w } \\
\end{array}$ & $\begin{array}{c}\text { Form } 30 \\
\text { Based } \\
\text { Pred.. } \\
\end{array}$ & $\begin{array}{c}\text { Cycle } \\
\text { Summary } \\
\text { Based } \\
\text { Pred., W } \\
\end{array}$ & $\begin{array}{c}\text { Form } 30 \\
\text { Total } \\
\text { Burnup, } \\
\text { Gwd/MTU }\end{array}$ & $\begin{array}{c}\text { Cycle } \\
\text { Summary } \\
\text { Total } \\
\text { Burnup, } \\
\text { GHd/MTU } \\
\end{array}$ & $\begin{array}{l}\text { Measured } \\
\text { Minus } \\
\text { Fom } 30 \\
\text { Based } \\
\text { Pred., W }\end{array}$ & $\begin{array}{l}\text { Measured } \\
\text { Minus } \\
\text { Cycle } \\
\text { Summary } \\
\text { Based } \\
\text { Pred., W } \\
\end{array}$ \\
\hline C2318 & $07-\operatorname{Dec}-84$ & 277.6 & 297.9 & 287.0 & 26.568 & 25.600 & -20.3 & -9.4 \\
\hline CZ331 & 24-\$ер-84 & 162.8 & 161.8 & 169.4 & 21.332 & 22.336 & 1.0 & -6.6 \\
\hline$C 2331$ & $21-$ Dec -84 & 180.1 & 158.3 & 165.8 & 21.332 & 22.336 & 21.8 & 14.3 \\
\hline CZ337 & $01-N o v-84$ & 347.7 & 346.4 & 346.0 & 26.720 & 26.691 & 1.3 & 1.7 \\
\hline$c 2337$ & 24-May-85 & 300.4 & 295.5 & 295.2 & 26.720 & 26.691 & 4.9 & 5.2 \\
\hline $\mathrm{CZ} 342$ & $07-0$ ec -84 & 280.1 & 320.1 & 307.7 & 27.066 & 26.013 & -40.0 & -27.6 \\
\hline CZ342 & $26-$ May-85 & 300.0 & 286.1 & 275.0 & 27.066 & 26.018 & 13.9 & 25.0 \\
\hline$C 2346$ & $27-0 c t-84$ & 388.7 & 375.5 & 369.9 & 28.048 & 27.559 & 12.2 & 18.8 \\
\hline$C 2348$ & $31-0 c t-84$ & 342.8 & 355.5 & 348.1 & 27.481 & 26.910 & -12.7 & -5.3 \\
\hline CZ351 & $10-$-Dec-84 & 313.8 & 297.1 & 300.8 & 25.753 & 26.074 & 16.7 & 13.0 \\
\hline C2355 & $28-0 c t-84$ & 290.5 & 293.0 & 285.9 & 25.419 & 24.803 & -2.5 & 4.6 \\
\hline$C 2357$ & $08-0 \mathrm{ec}-84$ & 320.3 & 326.3 & 318.9 & 27.140 & 26.528 & -6.0 & 1.4 \\
\hline C2369 & $25-0 c t-84$ & 347.6 & 348.3 & 336.6 & 26.576 & 25.680 & -0.7 & 11.0 \\
\hline CZ370 & 28-Sep-84 & 288.1 & 292.4 & 292.7 & 26.342 & 26.367 & -4.3 & -4.6 \\
\hline $\mathrm{C} 2372$ & $27-$ Sep- 84 & 288.8 & 286.3 & 296.3 & 25.848 & 26.748 & 2.5 & -8.5 \\
\hline $\mathrm{CZ} 379$ & $04-N o v-84$ & 287.4 & 296.9 & 291.3 & 25.925 & 25.438 & -9.5 & -3.9 \\
\hline C2398 & $27-0 \mathrm{ct}-84$ & 372.0 & 361.0 & 351.9 & 27.478 & 26.789 & 11.0 & 20.1 \\
\hline CZ4 415 & 26-Sep-84 & 289.3 & 286.7 & 296.6 & 25.863 & 26.752 & 2.6 & -7.3 \\
\hline$C 2416$ & $31-0 c t-84$ & 319.8 & 339.1 & 322.0 & 27.461 & 26.077 & -19.3 & -2.2 \\
\hline$C Z 429$ & $26-0 c t-84$ & 385.6 & 375.4 & 374.7 & 27.641 & 27.586 & 10.2 & 10.9 \\
\hline$c 2430$ & $3 l-0 c t-84$ & 353.3 & 344.2 & 344.5 & 26.825 & 26.848 & 9.1 & 8.8 \\
\hline$C 2433$ & $25-5$ ер-84 & 287.4 & 281.6 & 285.6 & 25.977 & 26.350 & 5.8 & 1.8 \\
\hline CZ4333 & $21-4 a y-85$ & 256.7 & 252.7 & 256.3 & 25.977 & 26.350 & 4.0 & 0.4 \\
\hline$C Z 460$ & $09-0 \mathrm{ec}-84$ & 313.5 & 308.9 & 305.5 & 26.512 & 26.222 & 4.6 & 8.0 \\
\hline CZ4466 & $28-\operatorname{Sep}-84$ & 302.1 & 309.4 & 299.9 & 26.077 & 25.280 & -7.3 & 2.2 \\
\hline$C Z 468$ & $11-$ Dec- 84 & 325.3 & 317.9 & 308.1 & 26.757 & 25.932 & 7.4 & 17.2 \\
\hline $\mathrm{C} 2472$ & $26-$ Sep- 84 & 325.0 & 321.2 & 323.8 & 25.957 & 26.171 & 3.8 & 1.2 \\
\hline$C 2473$ & $10-0$ ec- 84 & 293.2 & 297.6 & 285.1 & 26.519 & 25.409 & -4.4 & 8.1 \\
\hline$C Z 498$ & $25-0 \mathrm{ct}-84$ & 359.4 & 345.0 & 347.3 & 26.482 & 26.660 & 14.4 & 12.1 \\
\hline C2508 & $09-D e c-84$ & 310.0 & 309.6 & 304.0 & 26.357 & 25.882 & 0.4 & 6.0 \\
\hline$C 2515$ & $25-$ Sep-84 & 294.0 & 288.4 & 277.9 & 27.737 & 26.728 & 5.6 & 16.1 \\
\hline$C 2515$ & $26-0 c t-84$ & 296.0 & 282.7 & 272.4 & 27.737 & 26.728 & 13.3 & 23.6 \\
\hline$c 2526$ & $01-0 \mathrm{ct}-84$ & 395.4 & 384.2 & 396.9 & 27.596 & 28.511 & 11.2 & -1.5 \\
\hline$C 2526$ & 22-May-85 & 321.8 & 323.1 & $32 \% .1$ & 27.596 & 27.511 & -1.3 & -0.3 \\
\hline C2528 & $25-0 c t-84$ & 297.6 & 282.5 & 293.8 & 25.715 & 26.748 & 15.1 & 3.8 \\
\hline CZ531 & $30-0 c t-84$ & 347.2 & 343.2 & 343.0 & 26.699 & 26.686 & 4.0 & 4.2 \\
\hline$c, 2536$ & 27-Sep-84 & 295.2 & 296.1 & 294.8 & 26.589 & 26.473 & -0.9 & 0.4 \\
\hline CZ542 & $08-1) c-84$ & 311.9 & 312.4 & 303.9 & 26.691 & 25.969 & -0.5 & 8.0 \\
\hline$C 2545$ & $11-$ Dec-84 & 295.2 & 300.6 & 287.8 & 26.668 & 25.535 & -5.4 & 7.4 \\
\hline
\end{tabular}


1. Calibration Runs

A. Volume of water in calorimeter $=133.4 \mathrm{gal}$ measured heater attached. Weight of water $=(144.5)(8.31 \mathrm{~b} / \mathrm{gal})=1107.21 \mathrm{~b}$

B. Weight of pipe holding calibration heater $=151 \mathrm{lb}$

C. Heat capacity of system

$(1107.2 \mathrm{lb})\left(1.0 \mathrm{Btu} / 7 \mathrm{~b}^{\circ} \mathrm{F}\right)=1107.2 \mathrm{Btu} /{ }^{\circ} \mathrm{F}$

$(151 \mathrm{lb})\left(0.11 \mathrm{Btu} / \mathrm{lb}^{\circ} \mathrm{F}\right)=\frac{16.6 \mathrm{Btu} /{ }^{\circ} \mathrm{F}}{1123.8 \mathrm{Btu} /{ }^{\circ} \mathrm{F}}$

II. BWR - Dresden Fuel Element

A. Volume of water in calorimeter

BWR fuel assembly displaces $8.08 \mathrm{gat}$

$(8.08 \mathrm{gal})(8.3 \mathrm{lb} / \mathrm{gal})=67.1 \mathrm{lb}$

Thus, 1107.2

$-67.1$

1040.1 lb in calorimeter

B. From published information

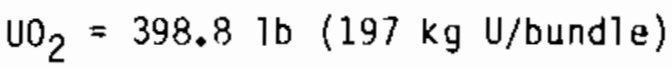

Weight of hardware $=216.8 \mathrm{lb}$

C. Heat capacity of system

During fuel runs, the calibration heater was removed; therefore, the volume of water would be increased slightly.

$151 \mathrm{lb}$ as steel $=18.2 \mathrm{ib}$ as water (equal volumes)

1040.1 ib

$+18.210$

1058.3 lb

$(1058.3 \mathrm{lb})\left(1.08 \mathrm{tu} /{ }^{\circ} \mathrm{F}\right)=1058.3 \mathrm{Btu} /{ }^{\circ} \mathrm{F}$

$(398.8 \mathrm{lb})\left(0.068 \mathrm{tu} /{ }^{\circ} \mathrm{F}\right)=23.9 \mathrm{Btu} /{ }^{\circ} \mathrm{F}$

$(216.8 \mathrm{lb})\left(0.11 \mathrm{Btu} /{ }^{\circ} \mathrm{F}\right)=\frac{23.8 \mathrm{Btu} /{ }^{\circ} \mathrm{F}}{1106.0 \mathrm{Btu} /{ }^{\circ} \mathrm{F}}$ 


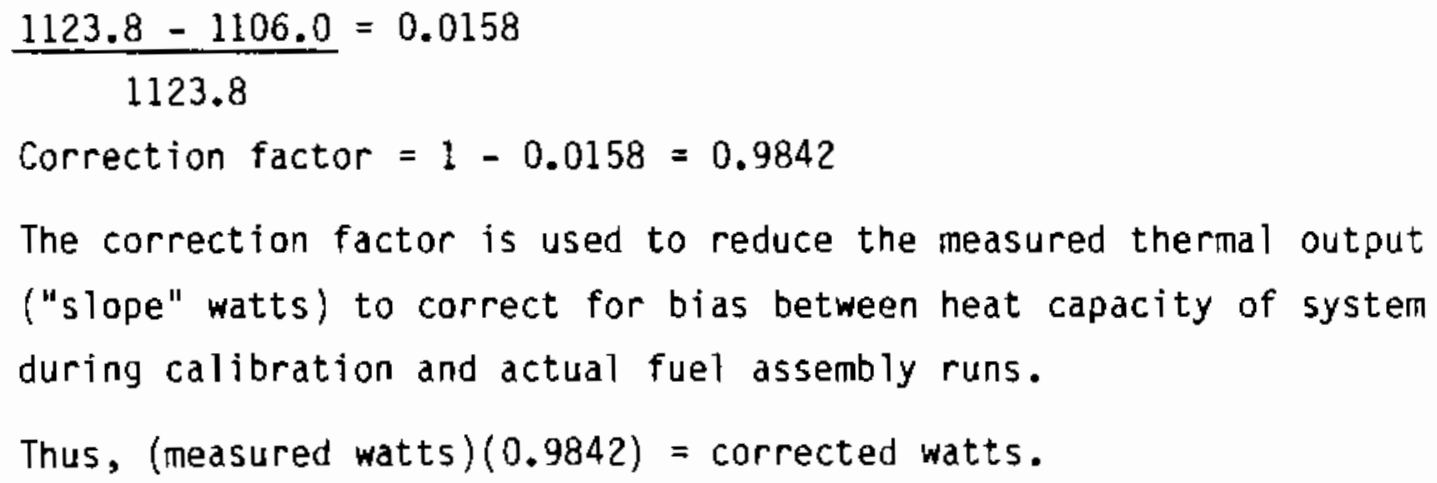

Because the walls of the calorimeter are not thick, some radiation passes through and does not contribute to the temperature rise within the calorimeter. It is essentially "lost" and, if not compensated for, will result in a negative bias in the calorimetric determination of the thermal output of the fuel.

In this analysis the following bases and assumptions apply:

1. Gamma energy absorbed in the inner steel shell of the calorineter is transferred as heat to the water in the calorimeter.

2. Gamma energy absorbed by the foam insulation is insignificant and is ignored.

3. Gamma energy absorbed in the outer steel shell of the calorimeter is transferred to the basin water, as infinite heat sink.

4. From dose rate measurements made by ion chambers mounted on both sides of the outer shell, the attenuation factor due to the steel shell was determined to be 2.16 .

The average energy of the gamo radiation traversing the outer shell may be calculated from the attenuation coefficient using the expression

$$
\frac{I}{I_{0}}=e^{-\mu x}
$$


where $I$ is the intensity of the transmitted radiation

$I_{0}$ is the intensity of the incident radiation

$x$ is the surface density of the absorber $=\mathrm{g} / \mathrm{cm}^{2}$

\lrcorner is the mass attenuation coefficient $-\mathrm{cm}^{2} / \mathrm{g}$.

The wall thickness is $0.953 \mathrm{~cm}(0.375 \mathrm{in.})$ and the surface density $(0.953 \mathrm{~cm})$ is multiplied by $\left(7.86 \mathrm{~g} / \mathrm{cm}^{3}\right)$ or $7.49 \mathrm{~g} / \mathrm{cm}^{2}$.

$$
\mu=\frac{1}{x} \ln \frac{I_{0}}{I} \quad \text { or } \quad \mu=\frac{1}{7.49} \ln 2.16=0.1028
$$

A mass attenuation coefficient of 0.1028 for iron corresponds to a gamma energy of $0.345 \mathrm{MeV}$ (U.S. HEW 1970, p. 138).

At an energy of $0.345 \mathrm{MeV}, 1 \mathrm{R} / \mathrm{hr}$ is equivalent to an energy fluence rate of $5.25 \times 10^{5} \mathrm{MeV} / \mathrm{cm}^{2}$ (U.S. HEW 1970, P. 132).

Because $1 \mathrm{~W}$ is equal to $6.24 \times 10^{12} \mathrm{MeV} / \mathrm{sec}$,

$$
1 \mathrm{R} / \mathrm{hr}=\frac{5.25 \times 10^{5} \mathrm{MeV}}{\mathrm{cm}^{2} \mathrm{sec}} \times \frac{1 \mathrm{watt} \mathrm{sec}}{6.24 \times 10^{12} \mathrm{MeV}}=\frac{8.41 \times 10^{-1} \text { watts }}{\mathrm{cm}^{2}}
$$

The calorimeter vessel is $15 \mathrm{ft}$ long and $22 \mathrm{in}$. in diameter. Its surface area at the inner surface of the outer shel1 is $3.1416 \times 21.25 \mathrm{in} . \times 180 \mathrm{in} .+$ $2(3.1416)(21.25 / 2)^{2}=12,795 \mathrm{in}^{2}=82,550 \mathrm{~cm}^{2}$.

For an outer surface dose rate of $I \mathrm{R} / \mathrm{hr}$ the inner surface dose rate is $2.16 \mathrm{R} / \mathrm{hr}$. Hence, the gamma energy lost from the calorimeter for an outer surface dose rate of $1 \mathrm{R} / \mathrm{hr}$ is

$$
\begin{aligned}
2.16 \mathrm{R} / \mathrm{hr} \frac{82550 \mathrm{~cm}^{2} \times 8.41 \times 10^{-8} \text { watts }}{\mathrm{cm}^{2} \mathrm{R} / \mathrm{hr}} & =0.01499 \text { watt } \\
\begin{array}{c}
\text { correction } \\
\text { factor }
\end{array} & =\frac{0.01499 \text { watt }}{1 \mathrm{R} / \mathrm{hr} \text { garma at outer surface }}
\end{aligned}
$$




\section{REFERENCES}

McKinnon, M. A., J. W. Doman, C. M. Heeb, and J. M. Creer. 1985. Decay Heat Measurements and Predictions of BWR Spent Fue1. EPRI NP-4269, Electric Power Research Institute, Palo Alto, California.

McKinnon, M. A., J. W. Doman, J. E. Tanner, R. J. Guenther, J. M. Creer, and C. E. King. 1986. BWR Spent Fuel Storage Cask Performance, Volume I: Cask Handling Experience and Decay heat, Heat Transfer, and Shielding Data. PNL-5777 Vol. I, Pacific Northwest Laboratory, Richland, Washington

U.S. Department of Health, Education and Welfare. 1970. Radiological Health Handbook. Revised ed. U.S. Government Printing Office, Washington, D.C. 
APPENDIX B

ORIGEN2 INPUT 
APPENDIX B

URIGEN2 INPUT

This appendix contains the operating histories used as input to the ORIGEN2 computer code, and the complete ORIGEN2 input for fuel assembly MT133.

TABLE B.1. Monticello Spent Fuel Assembly Operating History

\begin{tabular}{|c|c|c|c|}
\hline Cycle & Date & $\begin{array}{c}\text { Days } \\
\text { Since Startup }\end{array}$ & $\begin{array}{l}\text { Core Average } \\
\text { Power. MW/MT } \\
\end{array}$ \\
\hline 1 & $2-19-71$ & 0 & 0.0 \\
\hline 1 & & 18 & 0.54 \\
\hline 1 & & 57 & 0 \\
\hline 1 & & 95 & 5.45 \\
\hline 1 & & 120 & 0 \\
\hline 1 & & 145 & 14.17 \\
\hline 1 & & 157 & 0 \\
\hline 1 & & 187 & 14.17 \\
\hline 1 & & 195 & 0 \\
\hline 1 & & 266 & 13.08 \\
\hline 1 & & 347 & 0 \\
\hline 1 & & 507 & 16.90 \\
\hline 1 & & 514 & 0 \\
\hline 1 & & 518 & 11.99 \\
\hline 1 & & 530 & 0 \\
\hline 1 & & 664 & 17.44 \\
\hline 1 & & 671 & 0 \\
\hline 1 & $3-02-73$ & 742 & 17.44 \\
\hline 2 & $5-19-73$ & 820 & 0 \\
\hline 2 & & 848 & 14.39 \\
\hline 2 & & 852 & 0 \\
\hline 2 & & 892 & 16.79 \\
\hline 2 & & 903 & 0 \\
\hline
\end{tabular}




\begin{tabular}{|c|c|c|c|}
\hline Cycle & Date & $\begin{array}{c}\text { Days } \\
\text { Since Startup }\end{array}$ & $\begin{array}{l}\text { Core Average } \\
\text { Power, MH/MT } \\
\end{array}$ \\
\hline 2 & & 952 & 16.13 \\
\hline 2 & & 960 & 0 \\
\hline 2 & & 998 & 16.13 \\
\hline 2 & & 1003 & 0 \\
\hline 2 & & 1119 & 14.06 \\
\hline 3 & $5-19-74$ & 1185 & 0 \\
\hline 3 & & 1203 & 13.08 \\
\hline 3 & & 1207 & 0 \\
\hline 3 & & 1230 & 15.48 \\
\hline 3 & & 1235 & 0 \\
\hline 3 & & 1358 & 14.93 \\
\hline 3 & & 1362 & 0 \\
\hline 3 & & 1365 & 10.36 \\
\hline 3 & & 1371 & 0 \\
\hline 3 & $1-09-75$ & 1420 & 13.73 \\
\hline 4 & & 1449 & 0 \\
\hline 4 & & 1546 & 16.13 \\
\hline 4 & & 1549 & 0 \\
\hline 4 & $9-11-75$ & 1665 & 12.64 \\
\hline
\end{tabular}




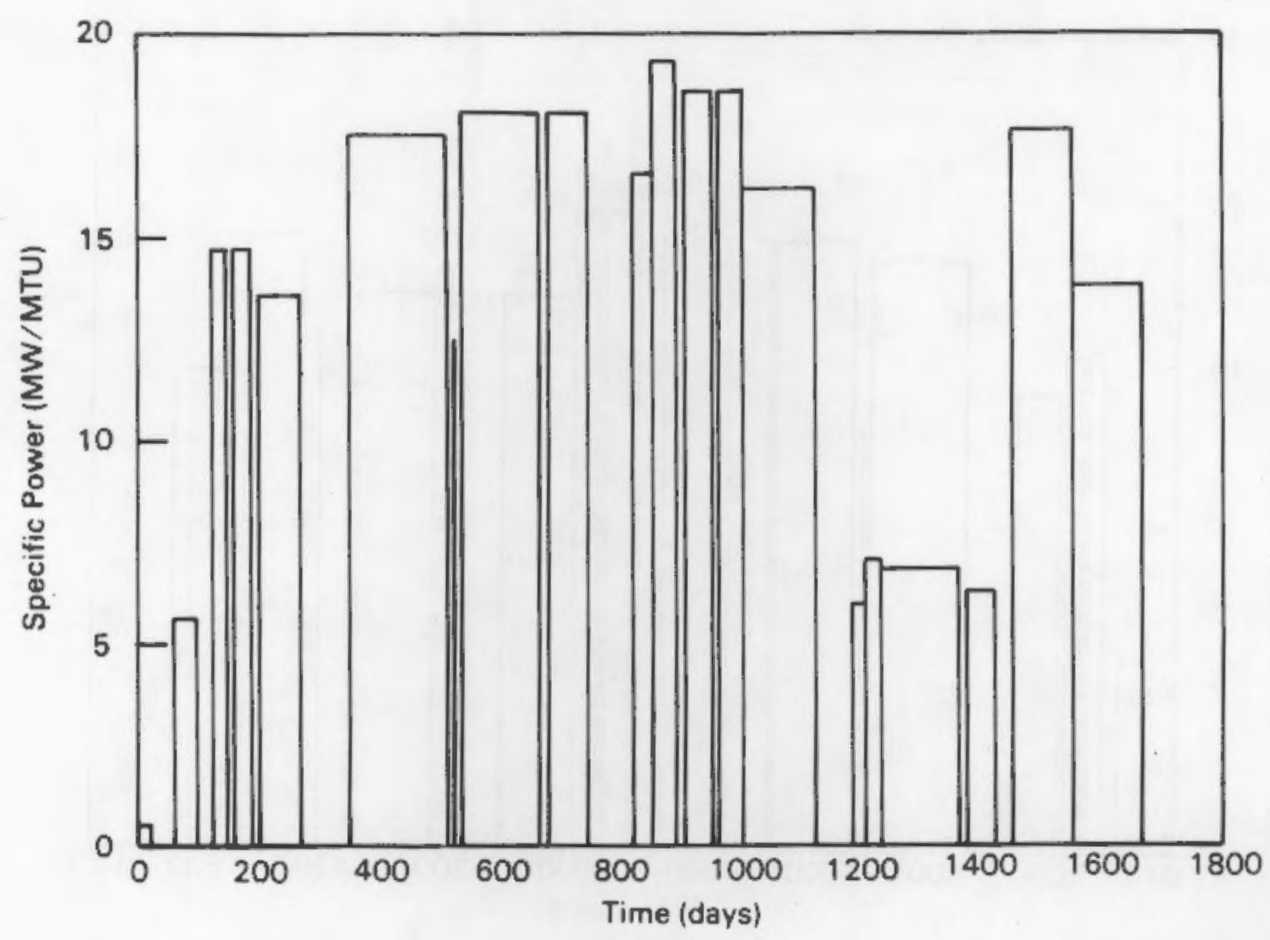

FIGURE B.1. Monticel10 Assembly MT116 Power History

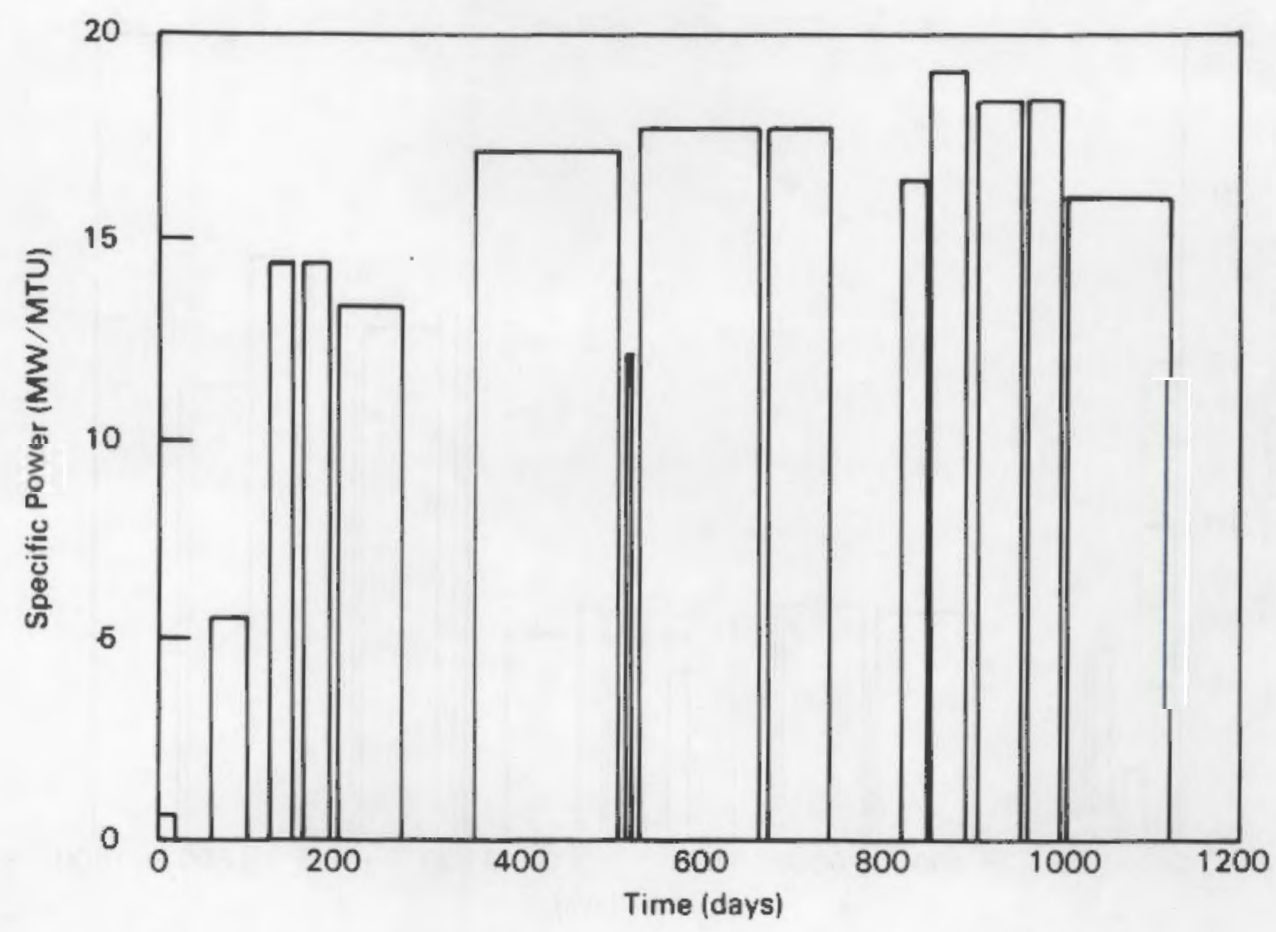

FIGURE B.2. Monticello Assembly MT123 Power History 


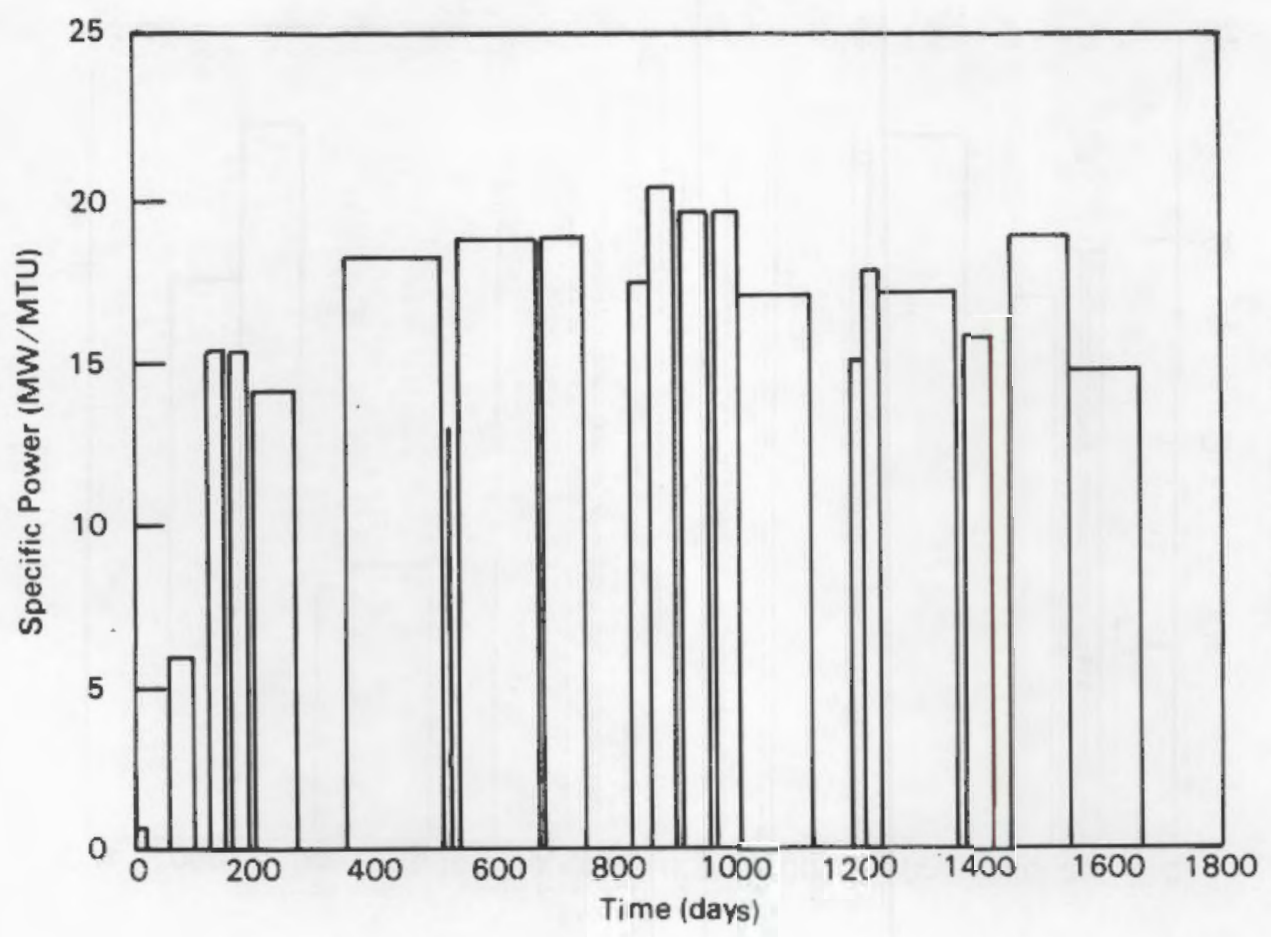

FIGURE B.3. Monticello Assembly MT133 Power History

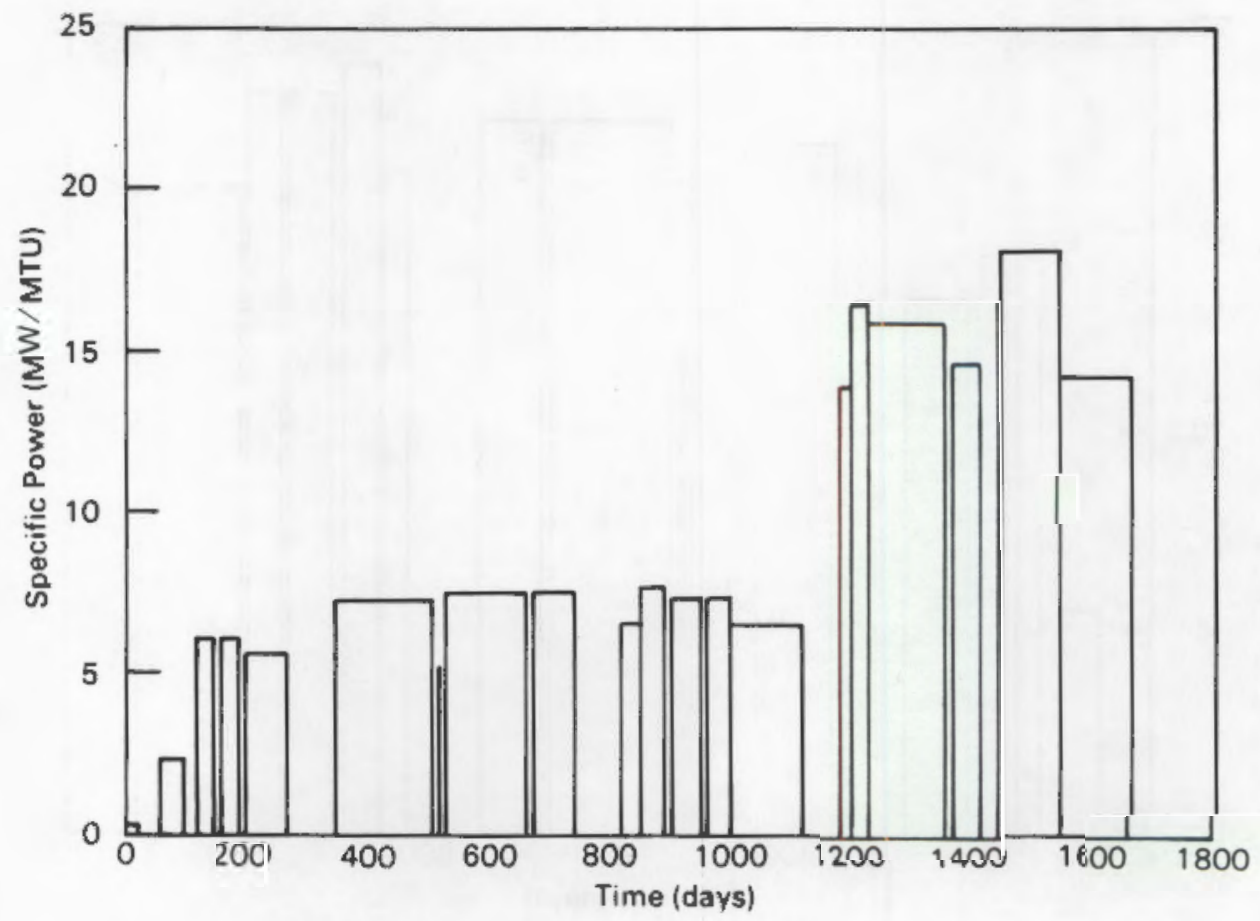

FIGURE B.4. Monticello Assembly MT190 Power History 


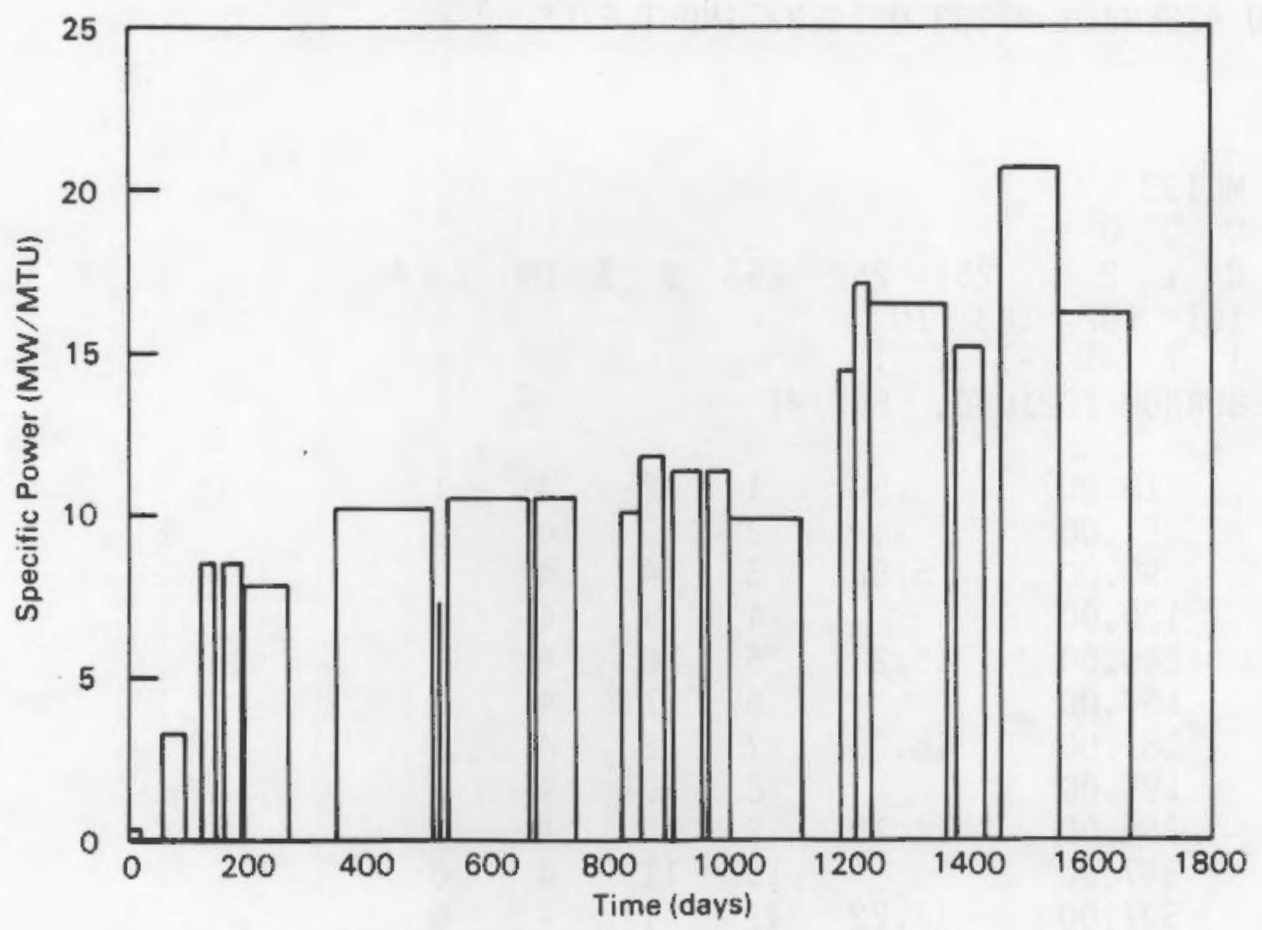

FIGURE B.5. Monticello Assembly MT228 Power History

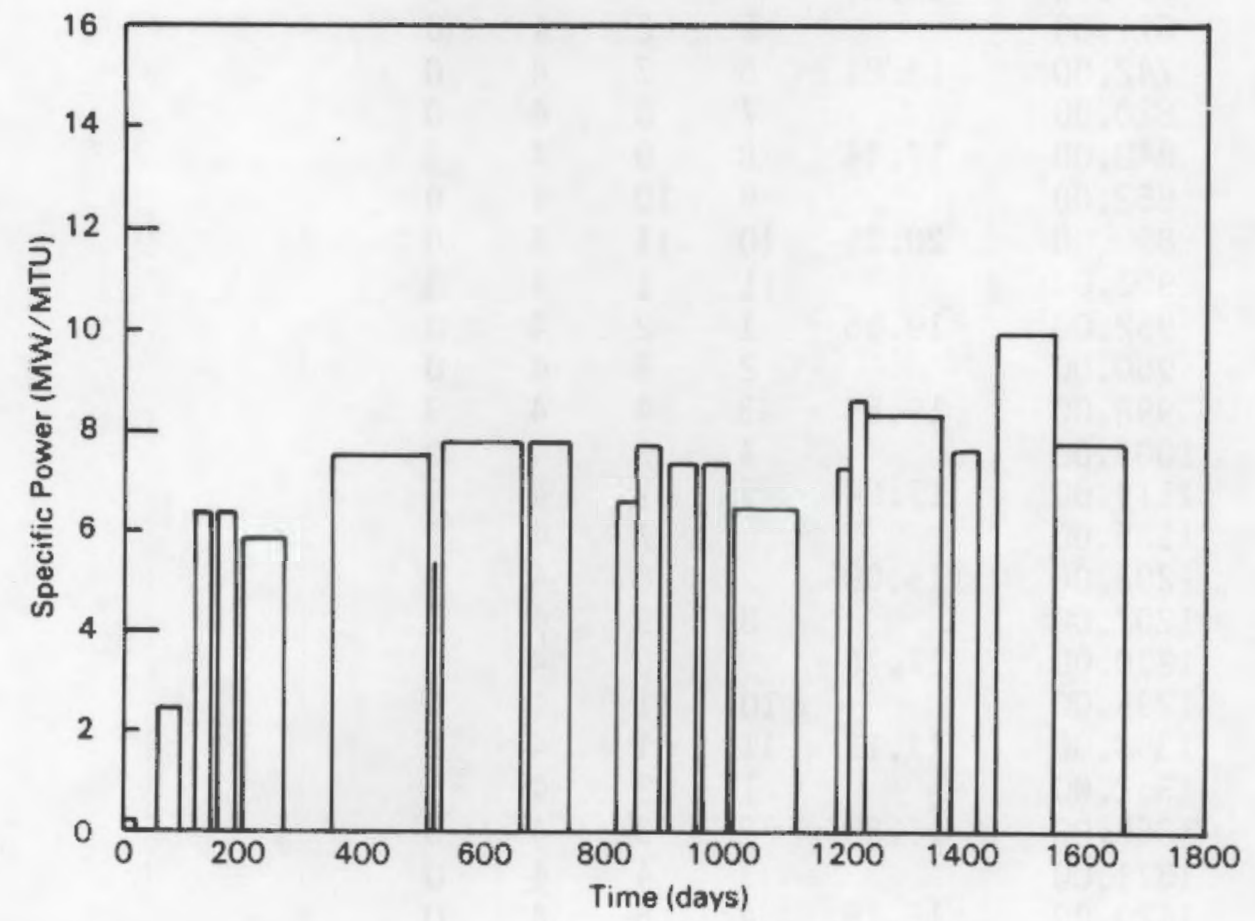

FIGURE B.6. Monticello Assembly MT264 Power History 


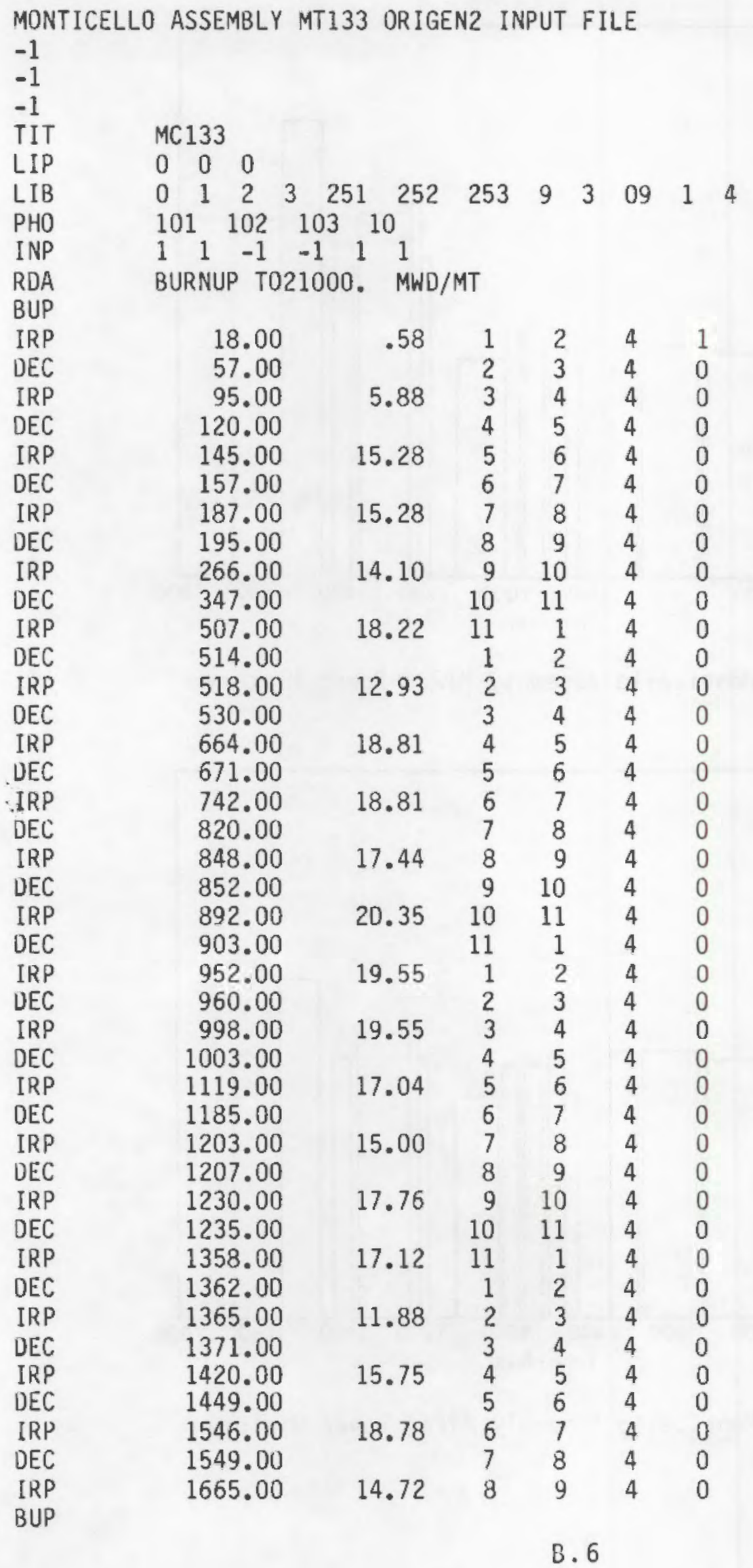




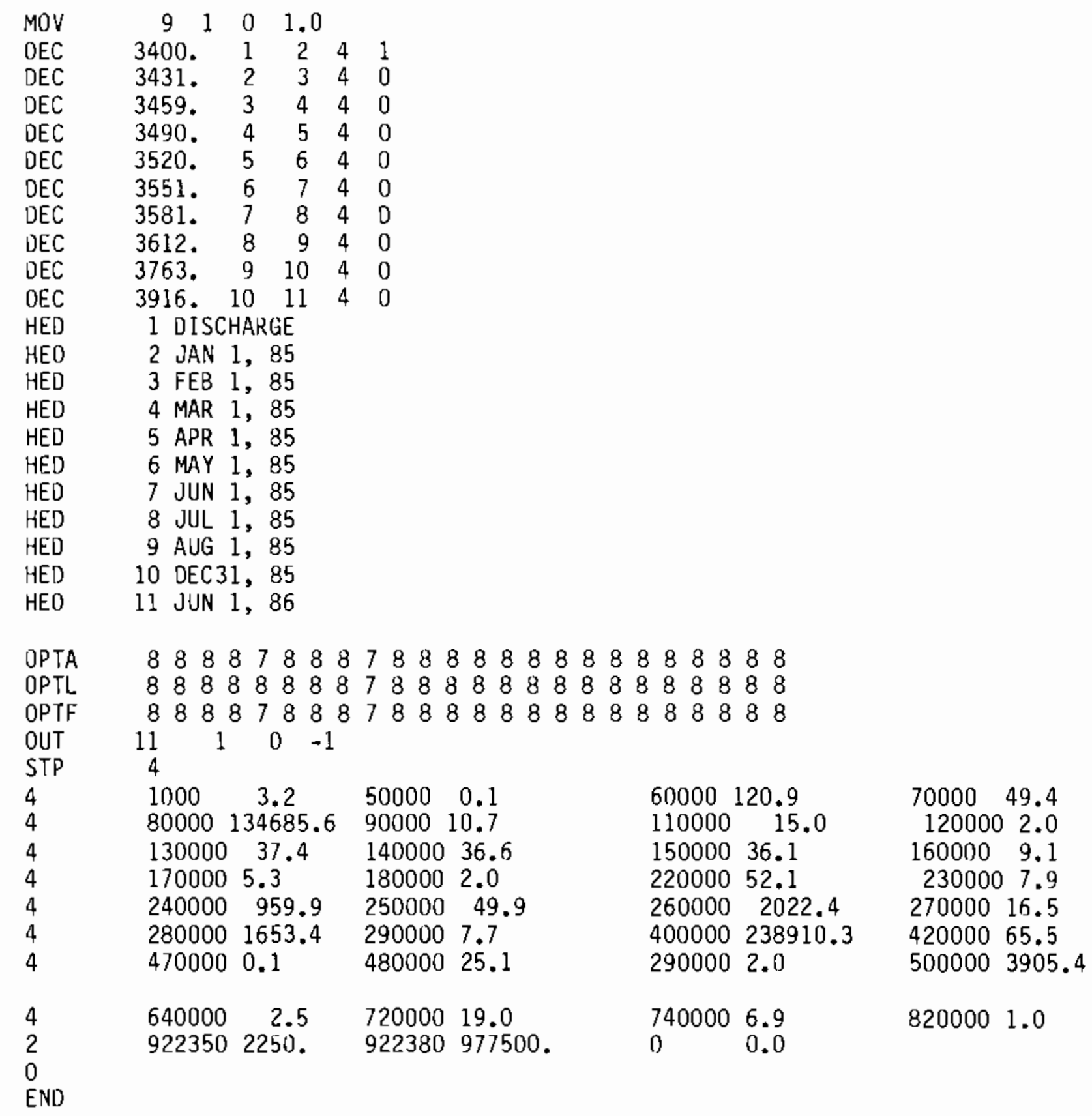




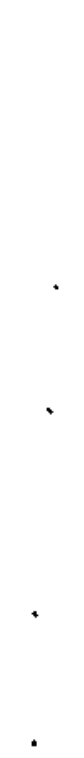




\section{DISTRIBUTION}

No. of

Copies

OFFSITE

110 DOE Technical Information Center

R. Bown

U.S. Department of Energy

Office of Civilian Radioactive Waste Management

RW-30

Washington, DC 20545

J. Epstein

U.S. Department of Energy

Office of Civilian Radioactive

Waste Management

$\mathrm{RW}-30$

Washington, DC 20545

J. R. Hilley

U.S. Department of Energy

office of Storage and

Transportation Systems

Washington, OC 20545

D. E. She? or

U.S. Department of Energy

Office of Civilian Radioactive

Waste Management.

RW-32

Washington, DC 20545

H. Steinburg

U.S. Department of Energy

Office of Storage and

Transportation Systems

$\mathrm{RW}-33$

1000 Independence Ave. Washington, DC 20585
No. of

Copies

W. Stringfield

U.S. Department of Energy

Office of Civilian Radioactive Waste Management

Washington, OC 20545

C. P. Gertz

U.S. Department of Energy

Idaho Operations Office

550 2nd Street

Idaho Falls, ID 83401

K. G. Golliher

U.S. Department of Energy

Albuquerque Operations Office

P.0. Box 5400

Albuquerque, NM 87115

L. Lanni

U.S. Department of Energy

Magnetic Fusion and Nuclear Division

San Francisco Operations Office

1333 Broadway

0akland, CA 94612

C. Matthews

U.S. Department of Energy

Oak Ridge National Laboratory

P.0. Box E

Oak Ridge, TN 37830

D. Veith

U.S. Department of Energy

Nevada Operations Office

P.0. Box 14100

Las Vegas, NV 89114 
No. of

Copies

N. H. Davison

U.S. Nuclear Regulatory Commission

Office of Nuclear Materials

Safety and Safeguards

Washington, DC 20555

C. Feldman

U.S. Nuclear Regulatory Commission

Office of Nuclear Regulatory Research

MS $5650 \mathrm{NL}$

Washington, DC 20555

W. Lake

U.S. Nuclear Regulatory Commission

Office of Nuclear Materials Safety and Safeguards

Washington, DC 20555

C. H. Peterson

U.S. Nuclear Regulatory Commission

Office of Nuclear Material Safety and Safeguards

MS 62355

Washington, DC 20555

J. A. Carr

Battelle Memorial Institute

Office of Nuclear Waste Isolation

$505 \mathrm{King}$ Avenue

Columbus, $\mathrm{OH} 43201$

B. A. Rowles

Battelle Memorial Institute

Office of Nuclear Waste Isolation

$505 \mathrm{King}$ Avenue

Columbus, $\mathrm{OH} 43201$

W. R. Juergens

Brooks \& Perkins

12633 Inkster Road

Livonia, MI 48150
No. of

Copies

R. Kunita

Carolina Power \& Light Co.

P.0. Box 1551

Raleigh, NC 27602

C. K. Anderson

Combustion Engineering, Inc.

1000 Prospect $\mathrm{Hill}$ Road

Windsor, CT 06095

Ebasco Services Incorporated

Two World Trade Center

New York, NY 10048

D. H. Schoonen

$E G \& G$

P.0. Box 1625

Idaho Falls, ID 83415

P. E. Eggers

Eggers Ridihalgh Partners, Inc. 1445 Summit Street

Columbus, $\mathrm{OH} 43201$

FLUOR Engineers, Inc.

Advanced Technology Division

P.0. Box C-11944

Santa Anna, CA 92711-1944

J. W. Doman

Morris Operations

General Electric Company

7555 E. Collins Road

Morris, IL 60450

E. E. Voiland

General Electric Company

Nuclear Fuel \& Services

Division

7555 E. Collins Road

Morris, IL 60450

R. Anderson

General Nuclear Services, Inc. 135 Darling Drive

Avon, CT 06001 
No. of

Copies

V. J. Barnhart

General Nuclear Services, Inc. 135 Darling Drive

Avon, CT 06001

L. B. Ballou

Lawrence Livermore National Laboratory

P.0. Box 808

Livermore, CA 94550

M. W. Schwartz

Lawrence Livermore National Laboratory

P.0. Box 808

Livermore, CA 94550

C. F. Smith

Lawrence Livermore National Laboratory

P.0. Box 808

Livermore, CA 94550

G. Bosler

Los Alamos National Laboratory

Los Alamos, NM 87545

P. Rinard

Los Alamos National Laboratory

Los Alamos, MM 87545

H. Lowenburg

Lowenburg Associates

1091 Rosemont Orive

Rockville, MD 20852

J. Houston

Nuclear Assurance Corporation

5720 Peach Tree Parkway

Norcross, GA 30092

R. T. Haelsig

NucTear Packaging Inc.

1010 S. 336th Street

Federal Way, WA 98003
No. of

Copies

L. E. Wiles

Numerical Applications, Inc.

825 Goethals Drive

Richland, WA 99352

J. V. Massey

NUTECH Engineers

145 Martinvale Lane

San Jose, CA 95116

C. E. Parks

Oak Ridge National Laboratory

P.0. Box $X$

Oak Ridge, TN 37831

D. Woods

Ralph M. Parsons Co. 100 West Walnut Street

Pasadena, CA 91124

T. L. Sanders

Sandia National Laboratory

Albuquerque, NM

M. E. Mason

Transnuclear, Inc.

1 N. Broadway

White Plains, NY 10601

B. R. Teer

Transnuclear, Inc.

1 N. Broadway

White Plains, NY 10601

TRW, Inc.

Energy Development Group

Suite 201

200 Union Blvd.

Denver, CO 80228

C. E. King

Uranium Mgt. Corp.

175 Curtner Ave. MC 620

San Jose, CA 95125 
No. of

Copies

M. L. Smith

Virginia Power Co.

P.0. Box 26666

Richmond, VA 23261

A. R. Hak 1

Westinghouse Electric Corp.

Waste Technology Services

Division

P.0. Box 10864

Pittsburg, PA 15236

J. H. Saling

Westinghouse Electric Corp.

Waste Technology Services

Division

P.0. Box 10864

Pittsburg, PA 15236

B. A. Chin

Mechanical Engineering

Department

247 Wilmore Labs

Auburn University, AL 36849

DNSITE

2 DOE Richland Dperations Office

R. D. Lzatt

J. P. Collins

2 Rockwell Hanford Operations

C. L. Brown

G. T. Harper
No. of

Copies

51 Pacific Northwest Laboratory

G. H. Beeman

L. W. Brackenbush

B. M. Cole

J. M. Cuta

J. M. Creer (10)

M. D. Freshley

E. R. Gilbert

R. J. Guenther

R. L. Goodman

R. J. Hall

C. M. Heeb

U. P. Jenquin

A. B. Johnson, Jr.

D. K. Kreid

N. J. Lombardo

R. A. McCann

J. L. MCElroy

M. A. McKinnon (10)

T. E. Michner

D. F. Newman

D. R. Oden, Jr.

D. R. Rector

R. A. Stokes

J. E. Tanner

D. S. Trent

C. L. Wheeler

Technical Information (5)

Publishing Coordination (2) 